$\therefore \ldots \because \ldots x+0$.

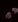

$82-$ 


\section{ZOOWOGV LENARY}

\section{dfilratry at}

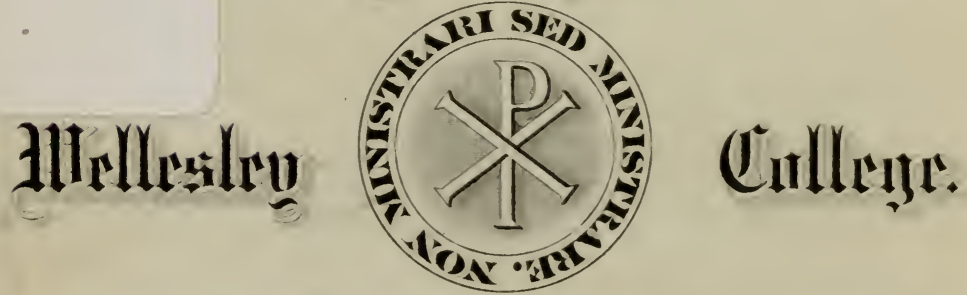

N9 81688

Humliand fram

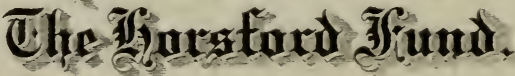


arn on

‥ 



\section{THE HISTORY AND THEORY OF VITALISM}




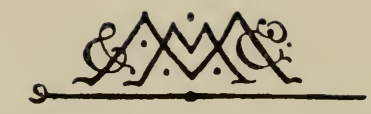

\section{MACMILLAN AND CO., LIMITED \\ LONDON - BOMBAY - CALCUTTA MELBOURNE}

THE MACMILLAN COMPANY

NKIV YORK - BOSTON - CHICAGO

DALLAS - SAN FRANCISCO

THE MACMILLAN CO. OF CANADA, Ltd. TORONTO 


\title{
THE
}

\section{HISTORY हृ THEORY \\ OF VITALISM}

\author{
$\mathrm{BI}$ \\ HANS DRIESCH
}

PROFESSOR OF PHILOSOPHY IN THE UNIVERSITY OF HEIDELBERG AUTHOR OF 'THE SCIENCE AND PHILOSOPHY OF THE ORGANISM"

'THE PROBLEM OF INDIVIDUALITY,' ETC.

AUTHORISED TRANSLATION BY

C. K. OGDEN

MAGDALENE COLLEGE, CAMBRIDGE

REVISED AND IN PART RE-WRITTEN FOR THE ENGLISH EDITION BY THE AUTHOR

MACMILLAN AND CO., LIMITED

ST. MARTIN'S STREET, LONDON 
COPYRIGHT.

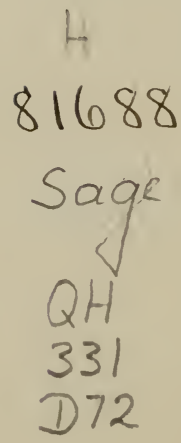




\section{TRANSLATOR'S PREFACE}

The many admirers of Professor Driesch in England and America will, it is hoped, welcome this succinct account of the Vitalism with which his name is so prominently associated, both in its historical and theoretical aspects.

Students of The Science and Philosophy of the Organism, the Gifford Lectures, 1907-8, by which Professor Driesch is perhaps best known to English readers, will find in Part II. of this book an account of the logical foundations of Vitalism, arranged in a rather different and in many ways easier form.

As the author explains in his Foreword to Part II., all the systematic section has been completely rewritten for the English edition ; and its arrangement is precisely the reverse of that adopted in the London Lectures, 1913, which are being published by Messrs. Macmillan almost simultaneously with this work. In the historical section the original text has been left substantially unaltered. This will account for a certain discrepancy between the philosophical views expressed in Part II. and those occasionally implied in the earlier pages-in particular as regards the author's position towards mechanical physics and metaphysics. The change is due to the fact that he no longer believes that 
qualitative Energetics can take the place of a real theory of matter (whether mechanical or electrodynamical). He now regards a critical metaphysic as possible, and no longer supports any kind of conceptual phenomenalism as the final word of philosophy.

My first debt as translator is, needless to say, to the author himself, with whom I have been in communication throughout the work; whom I also had the advantage of consulting personally during a visit to Heidelberg last summer, and on the occasion of his lecture arranged by Professor James Ward last October in Cambridge; and who has moreover most carefully revised the translation throughout. I wish further to express my special indebtedness to Miss O. H. Persitz, of Newnham College, for invaluable assistance, both philosophical and linguistic, at every stage of my labours.

From the Italian translation of this work by Dr. Stenta of Trieste, I have derived many useful suggestions, one of which is specially acknowledged on page 48 ; while Dr. R. Assheton, Mr. C. F. Angus, Mr. Wildon Carr, Mr. A. E. Heath, and Mr. K. R. Lewin have very kindly read through portions of the book in proof.

Where an English translation of a work quoted in the text exists-as in the case of Dr. Bernard's Kant's Kritik of Judgment-I have often availed myself of it without considering acknowledgment necessary.

C. K. OGDEN.

Magdatene College, Cambridge, March, 1914. 


\section{CONTENTS}

\section{CRITICAL INTRODUCTION.}

PAGE

The Different Kinds of Teleology - - - 1

\section{PART I. HISTORICAL.}

\section{CHAPTER I.}

\section{THE OLD VITALISM.}

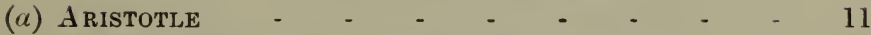

(b) The New Science and the New Philosophy - - 22

(i) The Old and the New - $\quad$ - $\quad$ - $\quad$ - 22

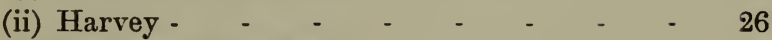

(iii) Georg Ernest Stahl - $\quad$ - $\quad$ - $\quad$ - 30

(c) Evolution, Epigenesis-and After - - - 37

(i) The Outcome of the Dispute - - - - $\quad 37$

(ii) Buffon. Needham. Maupertuis - - - 40

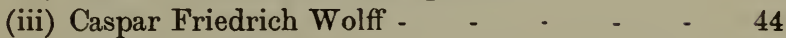

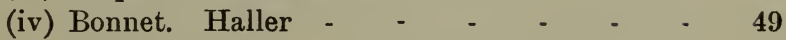

(v) Blumenbach - $\quad$ - $\quad$ - $\quad$ - $\quad$ - $\quad$ - $\quad$ - 57

(d) Kant-"Critique of Judgment" - - - - $\quad$ - 66

(e) The Vitalisu of the Nature-Philosophers - 93

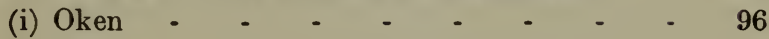

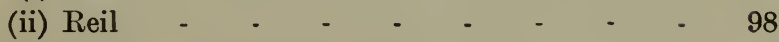

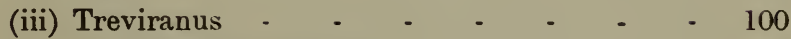

(iv) The Dogmatic School - - - - - - - 107

(v) Johannes Müller - $\quad$ - $\quad$ - $\quad$ - $\quad$ - $\quad$ - 113

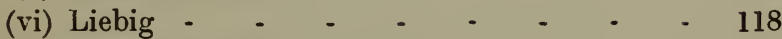

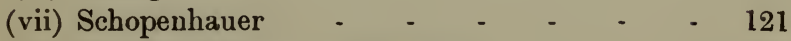

(viii) The End of the Old Vitalism _ _ - $\quad 123$ 


\section{CHAPTER II.}

THE CRITICS : AND THE MATERIALISTIC REACTION.
(a) Lotze
(b) Bernard -
(c) The Materialist-Darwinian 'Tendency -

\section{CHAPTER III.}

\section{MODERN VITALISM.}

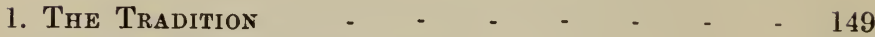

2. The Position of Philosophy - - - - $\quad$ - 158

(a) Eduard von Hartmann - _ - _ - 158

(b) Other Philosophers - _ $\quad$ - $\quad$ - $\quad$ - $\quad$ - 161

(c) Psychologists - $\quad-\quad$ - $\quad$ - $\quad$ - $\quad$ - $\quad$ - 161

(d) Edmund Montgomery - $\quad$ - $\quad$ - $\quad$ - $\quad 163$

3. The Anti-Darwinian Theory of Descent - - 167

4. Neovitalism - $\quad$ - $\quad$ - $\quad$ - $\quad$ - $\quad$ - $\quad$ - $\quad$ - 170

PART II. THEORETICAL.

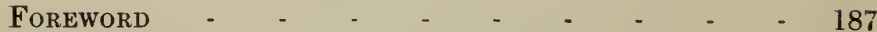

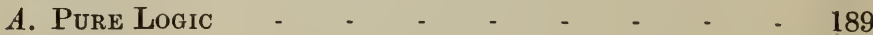

B. NAture - - - - - - - - - 190

C. Becoming - - $\quad$ - $\quad$ - $\quad$ - $\quad$ - $\quad$ - $\quad$ - $\quad$ - 191

D. The Forms of Becoming - - - - - . - 195

E. Individualising and Singular Causality - - 202

F. The Empirical Proofs of Vitalism - - - 207

$G$. The Problem of Suprapersonal Individuality - 216

H. Monism and Dualism - $\quad$ - $\quad$ - $\quad$ - $\quad$ - $\quad$ - 223

I. Metaphysical Conclusions - - $\quad$ - $\quad$ - 232 


\section{CRITICAL INTRODUCTION.}

\section{THE DIFFERENT KINDS OF TELEOLOGY.}

THE main question of Vitalism is not whether the processes of life can properly be called purposive : it is rather the question if the purposiveness in those processes is the result of a special constellation of factors known already to the sciences of the inorganic, or if it is the result of an autonomy peculiar to the processes themselves. For that there is, as a matter of fact, much that is purposive in vital phenomena is merely an immediate deduction from the definition of the concept of purpose itself, and from the application of this definition to living beings.

- In the language of everyday life, we designate as purposive such actions as experience shows to contribute directly or indirectly to a definitely desired end-or of which this is at any rate assumed. I judge all purposiveness in actions from my own standpoint: that is to say, I know for myself when my actions deserve the predicate purposive, because I know my own objects. With this I start. The actions of other men I describe as purposive if I understand the object which they have in view : that is to say, if I can imagine that that object could 
be my own, and consider them in relation to that object.

But I do not limit the application of the word purposive to the actions of other men: I extend it already in everyday life in two directions : and from this extension arises, on the one hand, the application of the word purposive or teleological to biology in general, and, on the other, the fundamental problem of biology itself.

I describe as purposive a great deal of animal movement, not only in certain of the higher animals whose movements are actually called actions, but also that group of movements which, in view of their constancy and coherence, are usually referred to not as actions but as instincts or reflexes. From these to the movements of plants which turn either towards or away from the light is a very short step, and it is only one step further to describe as purposive also those movements of growth which create out of the germ the complete organisms of animals and plants in a typical succession.

In this way, then, we finally get all phenomena in the living being which can be shown to be directed to a single point, thought of in some sense as an end, subordinated to the purely descriptive concept of purposiveness. From what we have said it will be seen that a certain arbitrariness is unavoidable in the designation of any event as teleological, for we can only proceed here by analogy. This arbitrariness, however, is not of any great consequence, as it may be stated once and for all that the term is used at this stage merely to give a certain orientation and nothing more. 
We have already said that, in order to describe a process as purposive, it must be connected with the idea of an end : it is thereby implied that the concept of teleology is extended to many processes of very different kinds, and also that it is limited to the organic in the first place, at least in so far as so-called natural objects in the narrower sense are concerned. For it is only in relation to organisms that the possibility of an end thus arbitrarily postulated can be thought of, at any rate without further consideration. This is due, among other things, essentially to the fact that relation to an end implies two things: in the first place, the special adaptation of the process in question to an end (or better, its position in a system of objects thus typically adapted), and secondly, its appearance in an indefinite number of individuals or examples-in short, its unlimited plurality. This is a postulate which in nature is fulfilled in organic natural bodies, and at the first glance only in them. We can therefore describe very many biological processes as purposive.

We do, however, as a matter of fact, also describe as purposive processes in certain objects which are not organic, but which are not objects of " nature" in the narrower sense-that is to say, in so far as we can speak intelligibly if not strictly of "culture" as an opposition to nature. The processes to which we refer occur in artefacts due to the action of men. Here we have our second extension of the concept purposive of which we spoke, and here we may start with our statement of the fundamental problem of biology.

I do not think it wise to describe machines, as 
things, by the term purposive. This word should be retained for processes, but every single process in a machine is purposive. We may call the machine as a whole "practical": it is the result of purposive action, of human action, but it is the fact that it is made for processes that distinguishes it from other human artefacts, from works of art for instance.

There are, then, inorganic things, namely, those made by men, which show us processes deserving the predicate purposive. It is clear that here the purposiveness of each single process rests on the specific order of the specific parts of the machine, and is determined by this order. In other words, each single effect in a machine is only purposive in so far as it is part of a higher specific whole; and this it is in virtue of the constitution or structure of that whole.

Our reasoning has now brought us to a point at which the problem which we have described as the fundamental problem of biology presents itself for consideration. We are confronted by the all important question: are those processes in the organism, which we described as purposive, perhaps only purposive in virtue of a given structure or tectonic, of a "machine" in the widest sense, on the basis of which they play their part, being purposive therefore only in the sense in which processes in a machine made by men are purposive; or is there another special kind of teleology in the realm of organic life?

It will be seen that we must first decide about the ultimate laws of phenomena which we have hitherto described only analogically in a more external 
manner, for it cannot be too often repeated that the mere assertion of purposiveness, mere teleology, to use the general technical expression, is purely descriptive. The term descriptive teleology will therefore be used definitely throughout the whole of this book to designate every descriptive view which deals simply with the existence of purposiveness. Descriptive teleology leaves the most important point still open, for life in particular this question: are the processes of life to be judged teleological only in virtue of their given order, only because a given mechanical form lies beneath them, while every single one is really a pure physical or chemical processor are the processes of life purposive because of an unanalysible autonomy?

For the future we shall use the terms static and dynamic teleology to mark this opposition, in distinction to merely descriptive teleology.

Static teleology leads to a mechanistic theory of the organism : the process of life and its order is only a special case of those laws which are valid elsewhere and of the general order of the world. The constellation of all the single cosmic elements just happens to be of such a nature that we also get amongst them those processes which are grouped together as "life." According to this view life is only distinctive as a combination and not because of its own laws. The question, whence comes the given order with which static teleology operates, is insoluble; and it is precisely owing to this circumstance that the lifemachine does appear to be something different from technical machines whose origin we know, even if the kind of purposiveness is the same in both cases. 
Dynamic teleology leads us to what is generally called Vitalism; it leads us to the recognition of the "Autonomy of vital processes."

Which of these two views is the right one?

The answer given in earlier times to this question, and the answer which we ourselves give, it is the purpose of this book to set forth; and the object of this introduction has been to prepare for such an exposition.

The result of this introduction, the recognition that is to say that there can be a static and a dynamic teleology gives us a critical reagent, a criterion by which we can test every body of doctrine offered by history : with it we can ask what is the real meaning of any theory, and we can do this even in those not infrequent cases when an author himself is very far from being clear as to the distinction between the concepts descriptive-, static-, and dynamic-teleology.

Our introductory remarks have been written to make easier our historical analysis and in consequence the understanding of the whole : they must be considered entirely as something preliminary and in no way our final view with regard to purposiveness.

Turning, then, to the examination of the earlier Vitalism and its development, we may remark once and for all that our treatment is concerned less with the personal element than with what is typical in the view we may be considering; and that consequently no weight is laid on completeness in the sense of a real history in the narrower sense, while on the other hand a suitable choice of material is of all the greater importance. If in spite of our search for the typical it is impossible for us to make our exposition 


\section{DIFFERENT KINDS OF TELEOLOGY 7}

appear not only as an historical but also at the same time as a logical development or progress, such as we find in standard histories of Mechanics or of the theory of Heat, our failure will only be blamed by those who are ignorant of the peculiarities of our subject. Mechanics is to a great extent an a priori "self-evident" science, and the same is true of a great part of physics, viz. thermodynamics: here discovery is to a certain extent only getting clear about one's own views, and chance circumstances play scarcely any part in questions of principle and very little in the historical development. Biology on the other hand is dependent in its progress in a very high degree on such chance circumstances, on "discoveries" in the narrower sense, and if its history is not wholly composed of such yet they are likely at any rate to obscure the really logical side of its progressive development. 
PART I.

HISTORICAL. 



\section{CHAPTER I. \\ THE OLD VITALISM.}

(a) ARISTOTLE.

IN an historical exposition of Vitalism which keeps the typical always in view, Aristotle may on the whole be regarded as representative of Antiquity. Moreover, since his views on biological matters form the basis of all theorising right into the eighteenth century, he has also every right to be regarded as representative of the medieval and early modern conceptions of life. The analysis of the Aristotelian theory of life must therefore be one of the corner stones of any historical work on biology.

Some parts of his works De Generatione Animalium and De Anima will come under consideration for our purpose. We shall begin by analysing the theoretical views exposed in the first of the above works in order that, after we have seen how Aristotle traces everything back to the activities of the soul, we may turn to the statements of the other, which are of a more fundamental nature.

It is highly interesting to realise that the first exponent of a scientific "vitalism" takes as his 
point of departure the problems of formation, or embryology as it is called to-day.

Already in this Aristotle is typical : and not only is he a typical representative of antiquity and the Middle Ages, but also a typical precursor of all vitalistic theories until the most recent times. In addition to the phenomena of co-ordinated animal movements, those of formation from the germ have always been the starting point of all Vitalism.

Male and female both contribute to the creation of new life, for they both secrete seed $\left(\sigma \pi \epsilon^{\prime} \rho \mu \alpha\right)$. But the female secretion, which Aristotle identifies with the monthly courses, supplies only the matter $(\dot{v} \lambda \eta)$, whereas the male determines the form and principle ${ }^{1}$ of the organic changes. The seed, as has been stated, need not come from the whole body, for " why cannot the seed at its origin be so created, that it can turn into blood and flesh without itself having to be blood and flesh ?" The mingling of the male and

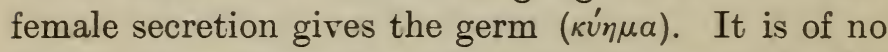
further consequence to us here that the germ divides

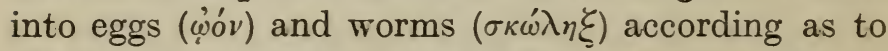
whether the progeny springs from a part only-in which case the rest serves as nutriment-or from the whole of the germ.

What part now does the male seed play in the development of that "superior and more divine"

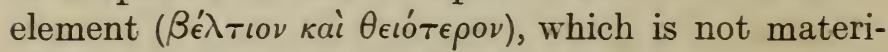
ally connected with the development.

Here begins Aristotle's theory of development. It

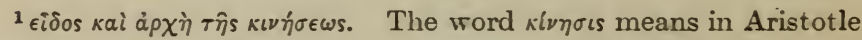
not only change of position : it is much more general. The same is true of $a \dot{p} \chi \eta^{\prime}$ which means not only beginning in time. 
is introduced by a clear formulation of the problem. "We must examine more closely the way in which a given plant or animal develops from the seed. For everything must necessarily arise out of some-

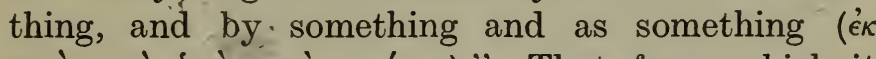

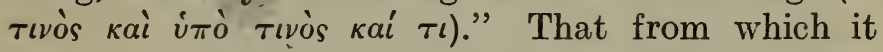
arises is the matter supplied by the mother. "We are concerned here not with that out of which, but with that by which the parts come into being."

The supposition that this conditioning factor by which the parts arise should be something outside the seed is rejected as contradictory: it therefore must lie within the seed, not indeed as something separated from it, but as a real part of it - transmitted to, and in turn becoming a part of the progeny.

Aristotle knows through various observations that the embryonic parts are not all simultaneously present, but come successively into being ; and thus, to use a modern term, we may call his theory "epigenetic." How then do these parts come into being : does the one form the other or do they simply arise one after the other? This somewhat dark question is briefly answered. The heart, the first visible part of the embryo, does not make the liver and the liver again another part, but one part comes into being after the other, just as the man succeeds the boy, but does not come into being through him. Otherwise, quite apart from the fact that there would be no ground for the formation of the heart, the nature and form of the liver would have to be contained in the heart: for, according to Aristotle, whenever anything is produced by nature or by 
art, there arises something which is potentially

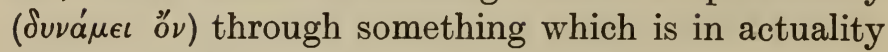

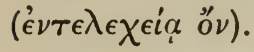

Thus we arrive at fundamental problems, and moreover at fundamental difficulties of the Aristotelian philosophy, and must therefore interrupt our exposition.

The question is as to the words dynamis and entelechy. By dynamis is not really meant what in modern terminology would be called " potentiality" or " potential energy," at least not that only, and in any case not in the passage to which we have drawn attention. The concept is much wider : by dynamis the statue is already contained in the block of marble, and indeed it is in this sense, as we shall see later on, that Aristotle uses the word in our passage. Entelechy is that which " is " in the highest sense of the word, even if it is not strictly a realised thing; in this sense the statue, before it is realised, exists in the mind of the sculptor. We can see that the concept of entelechy rather than that of dynamis corresponds, though not completely, to the modern concept of the potential.

But further logical examination being foreign to our present purpose we shall proceed with the exposition.

There lies a manifest difficulty in the fact that, as we have seen, one part of the growing body does not, according to Aristotle, condition the formation of another part, for this actually implies, to put it briefly; that the cause of the differentiation of the parts does not lie in the seed; on the other hand, the seed is to be regarded as a true part of the growing 
body. Yet it was stated earlier that the cause of the differentiation cannot lie outside the germ.

How is this knot to be unravelled?

An answer is found in the admission that, under certain circumstances, a thing can come into being by the action of something outside it. At this point Aristotle reintroduces' in a much wider form than before that scheme, which he had not considered applicable in the case of one organ being formed out of another, for instance, the liver out of the heart : "there is something which forms the parts, though not directly as an identifiable entity, nor yet as if the final development were already existent in it." 1

Morphogenesis as a whole is rather to be regarded as a kind of artistic creation :

"The manner in which each part arises" must be deduced from the principle that everything which comes into existence either in nature or in art,

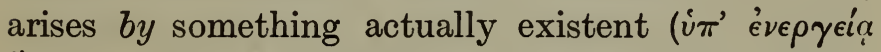
övтos), out of something, of a similar nature, potentially existent $(\delta v v \alpha \dot{\alpha} \mu \iota)$. Now the seed is such, and with such an impulse and principle, that, when the impulse ceases, each part comes into being and comes moreover endowed with soul." 2

This then is the main outline of the Aristotelian theory of development. The view, also elaborated, that each organic part is endowed with soul, that for instance a dead eye is improperly so called, is

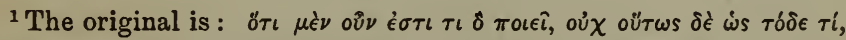

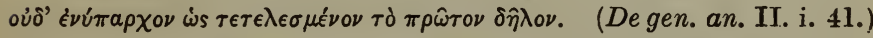

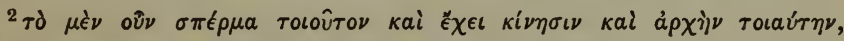

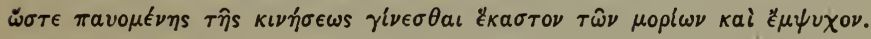


secondary to the chief contention : the seed forms the body out of the matter supplied by the mother, endowing it with a soul in virtue of a special principle; this principle it derives from another entity, from that which truly exists "in activity." It therefore plays an intermediate part. That which " is" in reality, from which everything derives, is the creator or rather his soul.

A gap in the text interrupts any further exposition; but the foregoing embodies the essentials.

All development therefore resembles to a great extent the production of works of art; Aristotle is always returning to this simile. It is interesting to notice with what nicety he points out the part of the inanimate factors, both in development and art-production : hardness, softness, and other qualities might well be influenced by heat and cold, but not

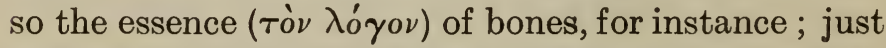
as heat and cold, though they make iron hard or soft, yet produce no sword.

The distinction between a work of art and one of nature is, however, not overlooked: "art is the source and form of what is becoming, working on something outside itself; but the movement of nature takes place in the thing itself, and proceeds from a second entity which has this form actually."

It cannot be denied that Aristotle's theory of development is not entirely free from obscurities; indeed I venture to state that the obscurities of the preceding argument are most probably not to be ascribed exclusively to my manner of exposition, however much this may leave to be desired. What 
in spite of all inspires us with the highest admiration for the great Greek thinker is the way in which he perpetually and manifestly struggles for clearness in this hardest of all nature's problems, how he turns over and over again and goes deeply into the same questions with the most delicate logical subtlety. How clumsycompared to this is mostmodern research.

Aristotle briefly disposes of the question as to how in each separate case the seed furnishes the developing organism with a soul : it transmits to the secretion of the matrix the same movement by which it is itself animated. This may happen because the female is in reality a mutilated male and because her monthly courses are seed which does not possess the principle of soul.

Those different stages of the "soul" which to a certain extent determine the various stages of the organic are of more importance for us: plants possess for their lifetime, and animals at the outset, only the nutritive soul ( $\tau \dot{0} \theta \rho \epsilon \pi \tau \iota \kappa^{\prime} \nu$ ), which is the soul of growth ( $\left.\alpha v^{\prime} \xi_{\eta \tau} \iota_{\kappa o ́} \nu\right)$ and also identical with

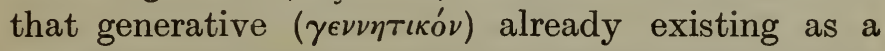
principle in the seed. Later on animals are endowed

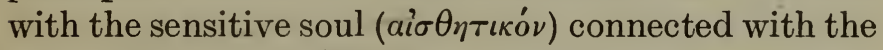

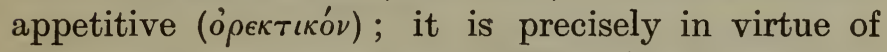
this that they are animals. Men alone have that third endowment Reason (voûs), which alone comes

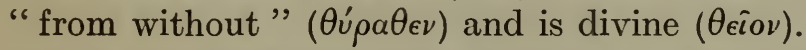

But this point leads into Aristotle's theory of the soul, and it will not be amiss to draw upon his three books De Anima for a few elucidations of the above exposition.

The possession of one of the stages of the soul 
above enumerated is sufficient to animate the body, for life in its broadest sense is "the nourishment, increase and decrease of a thing through itself." If it possesses many stages of the soul then all the lower are contained in the highest, "as the triangle is contained in the quadrilateral," and each lower stage serres the higher as a tool; for bodies are after all only tools (oopavov) of the spiritual, and "exist only for the sake of the soul."

It has already been explained that the soul as an actuality, as an "entelechy," organises the body; here again, and in a yet higher sense, Aristotle calls the soul "the principle $\left(\dot{a} \rho \chi \eta^{\prime}\right)$ of all things living," to reach later his famous definition that the soul in

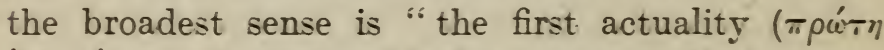
$\left.\dot{\epsilon} \tau \epsilon \epsilon \epsilon^{\prime} \chi \epsilon \iota a\right)$ of a natural body, having in it the capacity of life, and of one possessed of organs."

This, if the words be rightly interpreted, conveys all that the great thinker had to say : the soul is the sufficient ground for the existence of the organic body, for its mode of existence and for its behaviour in erery respect. The soul is actuality in the highest sense, i.e. in that of "scientific, not of immediate knowledge."

The question whether soul and body are one has as little sense as in the case of wax and its form. The soul cannot exist without a body, yet it is not the body but rather something inherent in the body ; "if the eye were a living being, then evesight would be its soul, this being the substance as notion or form of the eye ; and the eye would be the matter of the eresight."

All the lower stages of the soul serre as has been 
said as tools to human reason (vov̂s), as the highest stage. The passions belong to these lower stages; and it is not therefore the highest soul "which is angry or pities, but the man that does so with the soul." Old age, too, must be due to an affection not of the soul as such but of the body, in which it has its dwelling. "Thought, and the exercise of knowledge weaken with old age, because something else within decays ; thought itself is impassive."

Reason alone is immortal since it has come from without and is divine: when a body dies "there is neither memory nor love, for these never did belong to the thinking faculty but to the composite whole which has perished."

This must suffice to make clear the general lines of Aristotle's view of life; we cannot here enter on more subtle logical disquisitions concerning the conceptions Dynamis, Entelecheia, and Energeia, or into discussions about Matter ( $\dot{v} \lambda \eta)$, Form ( $\epsilon \hat{i} \delta o s)$, and Substance (ovंía); on Hegel, however, as is well known, these conceptions exercised a great influence. Aristotle's theory of life is pure Vitalism, and I may call it primitive or naïve Vitalism, for it arose from an entirely impartial contemplation of life's phenomena, and not as the result of struggle against other doctrines. Only very rarely, as in the remark that heat and cold do not yet make a sword, can a careful observer see that Aristotle was so much as aware of rival views : ${ }^{1}$ yet we know he was opposed

${ }^{1}$ In his De Anima he once attacks the view of Democritus that the soul must be moved in space because it can move.

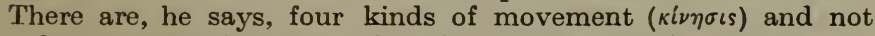
only movement in space : the other three are qualitative change, growth, and decay. Moreover, it is not necessary for that which moves to be moved itself. 
by materialists of the Democritean school and that Epicurus' teaching at a later date was responsible for yet other such adversaries. Perhaps Aristotle thought that the firm foundation of his theory or facts contrasted sufficiently with the airy hypotheses of the Democritean school to absolve him from the necessity of a detailed refutation.

Towards the end of the De Generatione Animalium, Aristotle summarises what, differentiates his concept of nature from that of his opponents. We may appropriately introduce the passage at this point, for it also summarises in concise language his vitalistic theory - his view about the autonomy of life :

"In the works of nature which conform to order and to law individual things do not possess their proper character in virtue of the fact that they have had such and such qualities from the beginning: it is rather because they are specifically such as they are that they are produced with such qualities. Their origin and development is determined by their essence (ov $\left.\sigma^{\prime} i^{\prime}\right)$ and are for the sake of that essence : the essence does not depend on the origin. The old nature-philosophers ( $\left.\phi v \sigma \iota \boldsymbol{\lambda}^{\prime} \circ \gamma \iota \iota\right)$ were of the opposite opinion, because they failed to recognise that there are several kinds of cause: they only knew the material cause and the efficient cause, and eren these not according to their difference, and left out of consideration the formal and final causes."

Modern philosophy can, however, borrow from the system of Democritus the concept of necessity in nature on which Aristotle does not lay sufficient stress-though the dogmas of the materialistic school may seem to us of no value. 
'The importance of Aristotle's bio-theoretical system cannot be overestimated. Although basing himself upon Plato, he rejected his influence in respect of natural science in its narrower sense, owing to his greater logical precision : in his conception of "Entelechy" he created the link between idea and reality which is lacking in Plato ; and this creation was just what the theoretical investigation of nature required. In biological, as in so many other matters, Aristotle is the authority till right into the middle of the eighteenth century, and for many right on into the middle of the nineteenth century. In the following considerations we shall meet with his views again and again under various forms.

The fact that our modern standards enable us to say: Aristotle "asserts" more than he proves, naturally does not weaken his influence upon a period which did not lay much stress upon verification. And we, who are proud of our insistence upon rigorous demonstration, and whose intellectual conscience has reached so high a degree of refinementwe, too, shall come to see at the end of this book that Aristotle's assertions have at any rate been justified by recent research. 


\section{(b) THE NEW SCIENCE AND THE NEW PHILOSOPHY.}

\section{(i) THE OLD AND THE NEW.}

THE real and fundamental difference between ancient and modern science is the habit, which began with Galileo, of quantitative and analytic thought about natural processes ; or one might also attribute it to the acquisition of the conception of natural law which dominates modern thought.

The ancients, it is true, knew of single quantitative relations in nature, such as the principle of the lever and the concept of specific gravity; but those were isolated instances : geometry alone among sciences connected with nature (I do not say "natural" sciences) was developed in a complete and general form.

We have the well-known description in the excellent works of Dühring and Mach how the great discovery of the law of falling bodies was followed by a constant sequence of further contributions, all of real importance for the understanding of natural law ; until, through the great systematiser Newton, there was effected a synthesis of all that had been hitherto attained. But all that had been attained was mechanics, both in the broad and narrow sense 
-an insight into potential and existing motions and equilibria of masses.

It is not surprising that so proud and victorious an advance in a sphere of knowledge which at that time was the sphere of knowledge, should have exercised its influence on the totality of all thought connected in any way with nature, and therefore on a great part of philosophy. Aristotle also had been particularly influenced by that special sphere with which he was most directly connected, that is by biology, although neither his method of investigation nor his information conform to the more exacting claims of to-day.

Thus, with the great philosophers of the Renaissance, the whole theory of nature is under the influence of mechanics, and is mechanical; and the theory of life also becomes mechanical.

In this book we need take philosophy into account not for its own sake, but only in so far as it reflects actual scientific thought. It will therefore suffice for our purpose (all the more because we are writing a history of Vitalism and not of the contrary theory) to remark that both Descartes and Leibnitz adopted a mechanistic view of life.

Nature as a whole, including the physical processes of life in the broadest sense, is for both a mechanical system, arranged by God. The spiritual, which they do not count with nature, is of course for them something thoroughly different, and therefore they are not metaphysical materialist; and Leibnitz particularly is at great pains to establish clearly the relation between the two great divisions of Being. But as far as nature itself, life included, is concerned, 
Descartes and Leibnitz and their followers behaved like materialists. Only in man, according to Descartes, is the mechanical causality of nature broken by the soul, but with Leibnitz there is not even a question (to use modern terminology) of a "psychophysical causality."

Such opposition as was forthcoming to the mechanistic theories of the philosophers was by no means suited to diminish their influence. Colourless Aristotelianism, diluted mysticism, inherited from the Middle Ages, was all that the supporters of Vitalism could bring forward: only thoughts about thoughts or about books, not, as with the great mechanists, thoughts based on an immediate study of nature. Hence one can readily understand how mechanism exercised such a deep influence on the schools ${ }^{1}$ of the so-called Iatromechanists and Iatrochemists; it was at least clear, one knew what it stood for, whereas all that one got out of J. B. van Helmont's ${ }^{2}$ Archeus, for example, was at best not more than an inferior edition of Aristotle's teaching about the soul.

As we have mentioned Helmont, a few words with regard to his personal views on the matter may be introduced here.

The fact that he professes to cast Aristotle aside, calling him ridiculous and ignorant (ridiculus and

1 Borelli (1608-1679), Hales (1678-1761), etc. Particulars in vol. ii. of Cl. Bernard's work mentioned in the preface. Also Boerhaave (1668-1738), whose Institutiones medicae (1708, 27th edition, Leiden 1721), a very important work, in that its general atmosphere is one of sober fact rather than of mere theory.

${ }^{2}$ 1577-1644. Chief work, Ortus Medicinae. New edition by his son: Amsterdam, 1652. 
naturae ignarus), need not affect our judgment : the finished form, the end, cannot be an effective cause, says the modern author in his zeal against the master of antiquity. ${ }^{1}$ Aristotle of course would never have

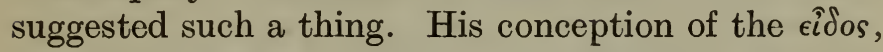
which appears as "forma" in Helmont, was too much of a refinement for the latter's mental capacity. The $\epsilon \hat{i} \delta o s$ is the absolutely and eternally real, but, in respect of each single realisation, it is the possible: as indeed the scholastics were well aware.

But Helmont believes he is saying something new when he introduces his Archeus (against Aristotle) as the "smith" (faber) who bears within himself the image of what he has produced and what he is going to produce, and arranges the course of development in conformity with those images. ${ }^{2}$ This is really and unmistakably the Aristotelian teachingonly less profound.

The fact, moreover, that Helmont is completely under the spell of Hebrew-Christian dogma and tradition (Paradise and Hell are constantly mentioned in his discussions), does not exactly enhance the

1 "Nam in primis, cum omnis causa . . . causato sit prior : certe, forma compositi causa esse nequit producti : sed potius Entelechia ultima generationis, ipsissimaque generati essentia, atque perfectio." The word "Entelechy" is here very imperfectly understood. "Forma enim, cum sit generationis finis, non est mere actus generationis : sed generati."

2 "Quidquid enim Aristoteles tribuit formae, sive perfectioni postremae, in scena rerum, id proprie, directive et exsecutive competit . . . Archeo seminali." "Ille inqu̇am faber, generati imaginem habet, ad cujus initium, destinationes rerum agendarum componit. Constat Archeus vero, ex connexione vitalis aurae, velut materiae, cum imagine seminali, quae est interior nucleus spiritualis, foecunditatem seminis continens." 
value of his teaching as compared with that of the unfettered Greek.

Not until the reappearance of a physiology and a theory of derelopment independently founded on observation, and to a certain extent experimental, are the great problems of biology treated in a manner worthy of closer discussion, and remored from scholastic and materialistic dogma. The reader will perhaps object to the word "independently" after having read the following sections dealing with Harvey and Stahl; to such a degree does everything remain dependent upon Aristotle's authority. Nevertheless, it is always new facts with which they are dealing and about which they are thinking, and their method is one which makes an honest endearour to win clearer views from a study of the actual objects or ideas in question.

\section{(ii) HARVEY.}

William Harvey (1578-1657), the discoverer of the circulation of the blood, and the champion of the famous "omne virum ex ovo" brings forward in his book Exercitationes de generatione animalium ${ }^{1}$ a large number of theoretical considerations concerning the nature of the process of derelopment which had forced themselves upon him in the course of his observations.

We have already been warned by His not to look for anything too modern in the "omne virum" phrase: Harrey was by no means opposed to the theory of spontaneous generation; which on the contrary he adopted for worms, insects, etc. His

${ }^{1}$ London, 1651. 
phrase is only intended to mean that if there are germs, their nature is uniform throughout the organic world, and is merely opposed to Aristotle's division of all germs into "eggs" and "worms."

But this is not our chief concern. It is Harvey's theory of conception that is of capital importance. It occurs "per contagium aliquod" as a kind of infection, just as illnesses occur ; but in opposition to Aristotle, Harvey holds that both father and mother play an essentially active part, that the function of the latter is not only to supply the material.

Conception, as is well known, is called "conceptio," just as the spontaneous appearance of series of thoughts is called "conception." This is completely justified : "sunt ambae immateriales" : neither of the "conceptiones" are material, in fact the uterus is in a way parallel to the brain.

It seems here as though Harvey had been led astray through a mere form of words, through the use of the word conception in two meanings without further reference to its theoretical consequences. The "aura seminalis" of later times is a true offspring of Harvey's theory of generation.

The egg which results from this process, and which is ready for development, is a singular object; it is in every respect a " medium quid," a mean, both between "principium et finis" and between the sexes, between the animate and the inanimate, and between matter and something that has in itself constructive capacity. It is not exactly a part of the mother, but lives on her through its own life as a fungus on a tree (propria sua vita). It is a "corpus naturale" but a natural body endowed 
with soul, though not animated by the mother's soul ; it is not "opus uteri" but "opus animae," the product not of the uterus but of the soul.

We recognise here both dependence on Aristotle and an earnest struggle for clearness in the subject itself ; Harvey looks, specially in matters of actual fact, with great respect back on his teacher Fabricius ab Aquapendente.

Before delineating the actual phenomena of development, he expressly ascribes to the egg the Aristotelian "anima vegetativa," "actu," the " anima sensitiva," " potentia."

The development itself occurs "potius per epigenesin quam per metamorphosin," rather through new-than through trans-formation (to anglicise the Graeco-Latin words which have become technical expressions).

The development occurs as though under the direction of an "opifex" i.e. a master builder; there is a certain "principium" in the germ cells, out of which and from which (ex quo et a quo) they issue. This principle could be called " primordium vegetale," something in itself existing and capable of taking on different forms. ${ }^{1}$

All this goes little further than Aristotle and is very indefinite. Harvey penetrates far deeper when he tries to lay down the differences between his "principium" and the conscious soul whose " higher" faculties he endeavoured to characterise. Certain of these characterisations closely resemble

1 " Liceat hoc nobis primordium vegetale nominare; nempe substantiam quandam corpoream, vitam habentem potentia; vel quoddam per se existens, quod aptum sit, in vegetativam formam $\mathrm{ab}$ interno principio operante mutari." 
views, which we find expressed much later by Johannes Müller :

That which is indigenous and innate (connatum et insitum) in the principle of nature, man has to learn; he, therefore, who with no further remark compares natural bodies with productions of art, is not a competent judge (aequus aestimator) of nature.

Harvey tries to improve matters with the words "deus sive natura naturans sive anima mundi"; and he ends by saying, in an almost epistemological form, that it only appears to our thinking (conceptui nostro) as if there were intelligence in the objects of nature, because we judge the divine works of nature accordingly to our capacities. ${ }^{1}$

Harvey is not a Vitalist in the interests of a preconceived theory any more than Aristotle; he wishes to put into words what he has found out about nature through experience; and obviously this to him takes the form of a peculiar vital autonomy. ${ }^{2}$ He proves just as little as his great precursor,

1 "Quoniam igitur in pulli fabrica ars et providentia non minus elucescunt, quam in hominis ac totius mundi creatione, necesse esse fatemur, in generatione hominis, causam efficientem ipso homine superiorem et praestantiorem dari.-Nam, quod in nobis operationum artificialium principium est, intellectus aut providentia, id in naturalibus acquisitum. Ideoque, ad artificialia qui respiciunt, haud aequi rerum naturalium aestimatores habendi sunt.-Fatendum est in naturae operibus nec prudentiam nec artificium neque intellectum inesse; sed ita solum videri conceptui nostro, qui secundum artes nostras et facultates de rebus naturae divinis iudicamus."

${ }^{2}$ Aceording to His, Harvey's teleology was rather indefinite and metaphysical than conceived as real, and would consequently be similar to the views of the later Philosophers of Nature. I find myself unable to subscribe to this view, however, and on 
but he struggles with deep earnestness after a more and more complete conception and exposition of the unveiled mysteries.

Harvey's theoretical conclusions did not have any great influence; and yet they are more critical and more cautious than the views of that successor who was considered during almost a whole century as the authority in matters vitalistic, and whom we shall now introduce.

-(iii) GEORG ERNEST STAHL (1660-1734).

The originator of the phlogiston-theory in Chemistry worked for many years as professor in Halle. In his Theoria medica vera, ${ }^{1}$ he imparts his views on life in general-views which be it said at once do not strike one as at all modern, and which we shall treat at some length only because of their great influence. Almost every writer on biology until the end of the Age of Enlightenment can be considered from the point of view of his relation to Stahl.

Stahl starts with a logical examination of the concepts organism and mechanism and the difference between them; the latter, he says, is subordinate to the former. Mixture and life (mixtio et vita) differ in the same way, as also "aggregatum et individuum " ; the living body has a "mixtio specialis" and an "aggregatio specialis" each of a great

the ground of his "primordium vegetale," "anima vegetativa," " opifex," etc., I believe that I am justified in seeing in Harvey a true Vitalist, a dynamic teleologist.

${ }^{1}$ Second edition, Halle, 1737. 
variety. It is just because of its extreme fragility that the living body requires special powers of preservation.

Chance (casus) then in the sense of Democritus or Epicurus is not a sufficient explanation of a living body; we must start from the everlasting laws, "leges aeternae," of the ancients. He rejects any machine theory in deliberate opposition to the Cartesians "qui corpus humanum machinam absolutam esse volunt," and who hold that the soul is superimposed on the body (superinduci), as it were for purposes of contemplation only.

The real conscious soul is the first cause of life. It is a threefold being (ens triplex), that is to say, an active, moving, reasoning being (ens activum, movens et intelligens), and creates the body, because it needs an "instrumentum." Therefore, only because of and through the soul, and for no other reason, does the organism exist ; 1 the soul however works upon the body by means of its passions (pathemata). The soul without the body would be impotent, both passively and actively. Its peculiar activity however is motion, directed and coordinated (motus, quos derigit et instruit).

If at this point we suspend our description for a moment, the "soul," according to Stahl's view, appears as the fundamental principle both of the origin of the body and also of all its functions. It is, in modern terminology, the subject matter of

1 "Non solum corpus simpliciter propter animam humanam, rationalem inquam, existere necessario oportet, sed etiam absolute propter nullam aliam rem." "Anima rationalis non solum corpori huic in est, sed etiam et per illud agit sentiendo, et in illud agit, motus locales producendo." 
functional physiology and of the physiology of development. ${ }^{1}$

Stahl knows very well that in ascribing all those activities to the reasonable soul, to the "anima rationalis" he is entering into disagreement with most other physiologists. In addition to the "anima rationalis," Aristole had allowed the " anima vegetativa" and the "anima sensitiva" ; to the last two he ascribes a certain " $\gamma \nu \hat{\omega} \sigma \iota s, " 2$ to the first alone does he grant " intellectus." Helmont on the other hand, spoke of a soul with higher and lower faculties, and this was moreover "plausibilis" because whoever can do much can also do little ("quod qui potest plus, potest etiam minus"). But on the whole all these inquiries are "steriles," and superfluous into the bargain: one can manage quite well with the "anima rationalis" alone.

Quite untenable is the objection that the reasonable soul cannot set anything in motion because it is immaterial : and in any case the difficulty, supposing it to exist, is not removed by mediating factors ; because they too are either material or immaterial, so that at some point of the chain that transition would have to take place.

Perhaps it could be urged that the reasonable soul has no knowledge or record of the vegetative functions (conscientia, recordatio et memoria); but Stahl destroys this objection also, first by means of

1 " Ipsa anima et struit sibi corpus, ita ut ipsius usibus quibus solis servit, aptum sit, et regit illud ipsum, actuat, movet, directe atque immediate, sine alterius moventis interventu aut concursu."

2 Stahl uses the Greek word which means something such as " instinctive knowledge." 
a "scholastic" 1 investigation (in a bad sense) and then by a process of argument far less objectionable and almost modern, saying that when the soul thinks or compares it does not know exactly what it is doing, and that the act of remembering is as such unconscious; ${ }^{2}$ precisely the same may be stated about the will, which does not really act with consciousness. Therefore, the fact that the soul is ignorant of anything does not disprove a causal relation.

There is after these fundamental statements no special interest in following Stahl's more detailed treatment, because with him single facts and their explanation hardly come into consideration: and only on what he says about the question of development of form need a few words be added.

It is an unnecessary multiplication of fictions (supervacuae multiplicationes rerum fictitiarum) to ascribe a "vis plastica" or a "spiritus genitalis" to the sperm, because the reasoning soul is sufficient for all ; for the rest, the fact of maternal impressions is decisive in favour of the soul. What remains doubtful is the question, how the parent soul can

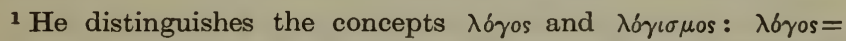
" intellectus simplex, simpliciorum, imprimis autem subtilissi-

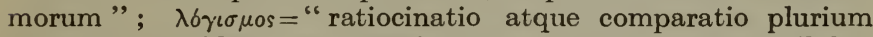
et insuper quidem per crassissimas circumstantias sensibiles, visibiles et tangibiles notorum."

2 "Imo altius cogitandum est, quod etiam in ipsis adeo ipsius rationis absolute propriis actibus, eorumque specifica et formali suprema determinatione constituenda, anima neque ratioconscientiam, saltem quod hoc agat, ne dum memoriam sive quomodo hoc egerit, quod tamen agit, habeat. Quotus quisque enim, aut quoties, cogitat quod cogitet ? Quis hominum ratione adsequitur, quomodo cogitet? Ne dum ut huius meminerit, quomodo factum sit?" 
at all be related to a body in process of formation and foreign to it. Now the soul is related not only to the "corpus formatum" but also to the "corpus formandum," not only to the formed body but also to that which is to be formed-and whoever is not satisfied with this explanation may propose something better.

The necessary dividing up of the soul is quite conceivable, because its functions, namely the movements, are divisible. ${ }^{1}$

I think the reader will not be unfair in describing these statements as "steriles et otiosae quaestiones," at any rate Stahl's treatment of the question is rather "empty and idle."

Before leaving Stahl, we will record his valuable reflection that it is not the mother's blood that creates the embryo, and will also give our author the chance once more to sum up his views.

" Propterea vero haec toties repetenda sunt, ut memori utique mente haereant, quod primae undique partes perpetuo sint actionum, minime vero materiarum : at actionum quidem minime in materiis, sed in materias : adeo ut hae ad illas simpliciter passive, et generaliter indifferenter sese habeant et omnino activae dispositioni atque coaptationi in quamlibet structuram atque figuram pure obsequantur. Quod notandum."

Or as freely translated: "It cannot be too often repeated that the basis of Life consists of activity not matter; and of activity not in matter but operating on it in such a manner that the matter

1 " Cum motus sit res adeo divisibilis, etiam movens videri potest divisibile." 
remains purely passive and indifferent, and merely obeys the activity which distributes and orders it in a given structure."

Had such a theory really any claim to exercise an influence over so many decades? Can we detect any advance however small on the biological views of Aristotle-and must we not rather admit an actual retrogression. Philosophy, in Stahl's day, was just awakening to the need for a critical theory of knowledge, and in view of this fact is not the epistemological framework of the whole unnecessarily confused? Certainly the fact that he was able to found a "school" must be ascribed to a large extent to the external authority which his name acquired as that of a professor who had long exercised a wide influence in his official capacity. That he was filled with a sense of his own importance is clear from the tone which pervades all his work, and from which nothing is further removed than the spirit of scientific research: for he is essentially a dogmatist, and scrupulously neglects everything which is in any way inconvenient to his theories.

Yet the effect of Stahl's book can also be understood without reference to such influences, even though it is wanting in those positive foundations which give such stability to Harvey's theories. It is the magnitude of his whole conception which strikes us in reading Stahl ; and his prevision of all logical consequences arising out of his views though such consequences especially when they threaten difficulties are often very summarily dealt with. The whole structure was, in point of theory of knowledge, not so clear as it ought to have been or indeed 
could have been, but it was at least free from mysticism. It was after all something very different from van Helmont's phantasies.

Stahl gave us the first great scientific system of theoretical biology after Aristotle; and as such a real system, as a logically constructed edifice, it had more influence than earlier efforts, similar to it but more phantastic (van Helmont); more influence than contemporary constructions with a better epistemological foundation but conceived in a meaner style (Harvey); more influence, finally, than contemporary systems of a weaker kind, ${ }^{1}$ with which it had to compete.

I doubt whether all those who later speak of Stahl have read the Theoria vera. He was known as a kind of type. I have never found anything quoted out of him.

Stahl's is an "Animist," not a "Vitalist" if we draw a distinction here : yet the difference was quickly lost sight of, and in the school of Montpellier, ${ }^{2}$ where Stahl's influence was specially great, there were to be found Vitalists of every degree.

And now we shall consider some scientific theories where matters of fact play a more important part than in what we have described so far.

1 The originator of such a theory was, for instance, B. F. Hoffmann (1660-1742): "Philosophia corporis humani vivi et sani," 1718, Opuscula medico-practica, Halle, 1736.

2 For details see Claude Bernard, II. 
(c) EVOLUTION, EPIGENESIS-AND AFTER.

(i) THE OUTCOME OF THE DISPUTE.

IT is pre-eminently the discovery of a large number of new facts that gives to the history of biology at the close of the seventeenth century its peculiar character; and as a result of these very facts new problems and new theories came into existence. Leeuwenhoek (1632-1723) had discovered the spermatozoa; ${ }^{1}$ Swammerdam (1637-1680) and Malpighi (1628-1694) and others had brought to light a multitude of facts bearing upon the embryology of chickens, frogs and insects ; Bonnet (17201793), Needham (1713-1781), Haller (1708-1777), Wolff (1733-1794), extended and developed these considerably; Réaumur (1683-1757), Trembley (17001784), and Spallanzani (1729-1799), discovered the power of regeneration in animals, chiefly through experiments made upon fresh-water polyps and worms. Any further treatment of these discoveries belongs to a general history of zoology.

It is the theories that were matured by the discoveries which interest us; but these theories

1 Or rather they were discovered under his direction. The student Hamm was actually the first to see them. 
are connected with the formulation of certain problems, of which three rose into pre-eminence: the question of the laws regulating the embryology of the organism, the question of the laws which govern regeneration, and the question of the origin of the germ. The last question includes the problems of generation, and of so-called heredity, and also that of so-called "spontaneous" generation.

The theories, or attempts at a solution of these problems, group themselves in the following logical framework.

Development can take place either on the ground of a pre-existence of the form in the germ (in which case it is only growth of something already existing), or it is the construction of something differentiated out of something more or less undifferentiated. This division gives us, to begin with, the comprehensive fundamental concepts of evolution and epigenesis.

Now the conception of evolution may be confined to the actual development from the germ, whereas the genesis of the germ itself is regarded as a new formation, as epigenesis ; or on the other hand, all new formation may be denied. The theory of evolution then becomes the theory of "emboitement," and it is asserted that all germs boxed up in each other have pre-existed ever since the creation. Here again a division takes place on the ground as to whether the male or the female contribution to the germ is the bearer of this enclosed element. We thus get the two schools of the "Animalculists" and the "Ovulists."

Epigenesis, on the other hand, may be thought of not only as new formation of something organised 
out of that which is absolutely devoid of order, but also as the new formation of the highly organised out of an organisation of a lower order.

This last concept leads us on to modern views; it reconciles to a certain extent evolution and epigenesis. But it was just this concept which was the last to be adopted by the older thinkers with whom we are here concerned. Hence, we must beware of attributing to them ideas which are familiar enough to us. The mere fact that for them the conception of epigenesis, at any rate to begin with, is invariably connected with the conviction of the reality of spontaneous generation warns us to be careful.

The more important investigators distribute themselves as follows among the various possible views which we have distinguished.

Swammerdam, Malpighi, Bonnet, Haller, Spallanzani and others are evolutionists in the strictest and broadest sense, and "Ovulists" too ; Leeuwenhoek, Hartsoeker and others, of whom Leibnitz is one, are "Animalculists." Needham and Maupertuis are thorough-going supporters of epigenesis, and so is Buffon for the genesis of the germ, though an evolutionist as regards its development. Wolff and Blumenbach may be reckoned the chief representatives of an improved epigenesis ; and with them we reach the threshold of a new period.

All believers in epigenesis are Vitalists, and it is just for this reason that the whole controversy is of such great importance to us. And yet with regard to their theoretical position a few only of the writers we have named can be considered of any importance; and some of the most eminent 
of the observers and experimenters, curiously all evolutionists, are the least conspicuous for the independence of their theorising. Such are Swammerdam, Leeuwenhoek, Spallanzani, Réaumur, Trembley and others.

We shall now endeavour to gain a somewhat closer acquaintance with scientists of theoretical importance during this period.

(ii) BUFFON. NEEDHAM. MAUPERTUIS.

In his famous Histoire Naturelle ${ }^{1}$ George Louis Leclerc Buffon submitted the processes of generation and development to a searching analysis, and we have already pointed out how to a certain extent this analysis led him into both the opposed camps.

A tree, a polyp, in short all organisms which have the power of readjusting their structure or of multiplying by means of buds, are to be thought of as consisting of nothing but small parts from which they may spring again. These parts are as it were the organisms themselves on a small scale, just as the single crystals of a cube of salt are the cube itself in miniature. In those organisms which are deprived of the power of budding and of regeneration, the germs at any rate are such wholes in miniature. All growth is thus only the putting together of similar parts already present according to their nature; the tree is already in the grain.

This is orthodox evolutionism. But now the question arises for Buffon: are all future grains contained in that grain? He answers this question in the negative-to invent a theory which on the 
one hand makes him a Vitalist, and on the other bears a certain degree of resemblance to Darwin's famous theory of Pangenesis. ${ }^{1}$

It is an "inner form," a "moule interne," which, already representing the whole as manifold, directs its development, i.e. the mere growth, and imparts order to the newly-set substance. This order arises "from the arrangement of all the parts of the inner form."

What is the origin of this "moule interne"? It does not lie in some other pre-existing form-that would be absurd ; it is the result of peculiar forces which are due to the element of life itself. It is interesting to note that Buffon ascribes to these forces that ordered juxtaposition of molecules which arises from the ordered nature of the inner form; so that his own evolutionistic theory of development, is also not properly a " machine theory."

But the forces of which the "moule interne" is the result, act in such a way as to appropriate to themselves all superfluities from the material which promotes growth $^{2}$ and collect it in a specific order in the genital organs; here lies the analogy with the theory of pangenesis. Like all our author's views which refer to the physiology of nutrition, the details of the account remain more or less obscure. At any rate the origin of the germs is

1 It should be noticed here that the ancient view, rejected already by Aristotle, according to which the seed has its origin in the whole body, was a precursor of Darwin's theory.

${ }^{2} \mathrm{He}$ sees in the spermatozoa superfluous particles forming the "moule" : they would themselves severally be neither able to develop nor to generate, and in any case they are not, as Leeuwenhoek would have them, preformed animals. 
here interpreted in a truly vitalistic sense, and we have already briefly noted that Buffon, in spite of his evolutionistic theory of development, allows that the formation of the germs is effected by peculiarly vital forces.

In order to justify his position Buffon chiefly combats the Cartesian theory : it seemed to him "a vain and baseless procedure to refuse to attribute to matter any properties outside those which we have already discovered it to possess." The " moule interne" is therefore a force quite as specific as gravitation.

Here Buffon is clearly on quite modern paths; and in general he discusses scientific methodology with so much acumen that I cannot refrain from quoting :

"Le défaut de la philosophie d'Aristote étoit d'employer comme tous les effets particuliers, celui de celle de Descartes est de ne vouloir employer comme causes, qu'un petit nombre d'effets généraux, en donnant l'exclusion à tout le reste. Il me semble que la philosophie sans défaut seroit celle où l'on n'employeroit pour causes que les effets généraux mais où l'on chercheroit en même temps à en augmenter le nombre, en tâchant de généraliser les effets particuliers."

Buffon lays stress upon the fact that he in no way intends by his postulation of a special life-force to cast any doubt on the fundamental principles of mechanics, which do but describe the universal workings of nature.

We shall I think meet with general agreement if in summing up our critique of Buffon's achievements we judge the methodological justification of his 
Vitalism more important than the Vitalism itself. Vitalism he did not even try to prove by way of trial, but the fact that Buffon did try to demonstrate its scientific legitimacy raises a naive into a conscious theory. Where Buffon is greater than Stahl (though the latter's analytic leaves Buffon far behind) is in the fact that he deliberately affirms : I am saying something new compared with the mechanistic theory, but $I$ have the right to say it.

Buffon's influence was profound : and in particular we find among his disciples two writers who endeavoured to pass beyond their master in the development of their own theories-the President of the Academy of Berlin, Maupertuis, known chiefly because of his mechanic "principle of least resistance," and the English Jesuit, Needham.

Maupertuis laid down his views upon organic formation in his work Venus physique (1746). He tries to establish a parallel between organic formation and phenomena of crystallisation, and in particular the case of the "arbor Dianae," which played a great part in the literature of that time; there is an ordering force even in the product resulting from the mixture of the male and female elements, and this force decides the right combination of the parts and later on maintains them in their growth. The whole theory is clearly a variant on that of Buffon.

Turberville Needham ${ }^{1}$ even expressly emphasises his agreement with Buffon's theories. Yet, Need-

1 Nouvelles observations microscopiques, avec des découvertes intéressantes sur la composition et la décomposition des corps organisés, Paris, 1750. Especially the section beginning : "Observ. nouv. sur la génération, la composition et la décomposition des substances animales et végétales." 
ham's chief interest is directed towards something other than these theories, namely, towards a spontaneous generation from decomposed organic substances. From its alleged existence he draws all proofs that there is in nature a "force réelle productrice," "une force végétale dans chaque point microscopique de matière végétale ou animale." The fact that at the same time he denies the "germes préexistens " in actual propagation, certainly results from his general view, but in matters of detail he as good as neglects properly morphogenetic problems altogether. He emphasises even more than Buffon the irreducible, or the vitalistic, element of the doctrine.

Needham regards his view as compatible with the general principles of mechanics, and he gives us particularly disquisitions on matter and mechanics. There too a great deal strikes us as very modern : "La matière n'est qu'un pur phénomène, un résultat complexe et un concours de plusieurs effets différens."

Needham declares the intelligent soul to be something entirely different from the formative forces of nature.

We are hardly inclined to see any real progress in his achievements as a whole. ${ }^{1}$

(iii) CASPAR FRIEDRICH WOLFF.

Caspar Friedrich Wolff (1733-1794) is usually looked upon as the father of epigenetic descriptive embryo-

${ }^{1}$ His in his Körperform (pp. 221, 222) refers to various passages in Needham's works ; we read how Eve was formed by a sort of budding, and learn that Needham discussed with his Jesuit colleague, Spallanzani, the claims of evolution and epigenesis from the point of view of orthodoxy. 
logy. We meet with this opinion especially in the historical sketches of materialistic Darwinians, and Wolff is there sometimes claimed as a precursor of Darwin. This fact shows that it has not always been made clear that his theory of development was not only epigenetic, but, like all epigenetic theories, also vitalistic; that is why Wolff interests us here.

His Theoria Generationis appeared in 1759; in 1896 Samassa arranged a German translation of the Latin original.

The system of predelineation or preformation, says Wolff, does not explain but rather denies development. The chief thing is to deduce the "parts of the body and the manner of their structure" from principles and laws. Such a theory of development or "rational anatomy" would be related to descriptive anatomy like rational to empirical psychology, or like philosophic and historical knowledge.

This is profound and extremely promising; it shows that the conception of something like our modern " physiology of development" was vaguely before Wolff's mind.

Wolff then enters into a discussion of the principal question :- "How are life and machine connected in organic bodies?" Are they both dependent on one common cause, or on one another; and if the latter, is life productive of mechanism or vice versa?

The case of plant physiology is first adduced. The force which drives water into the plant "cannot be an attractive force only"; this " is proved by transpiration." Nor is the absorption of moisture dependent 
on the saturation of the atmosphere and its expansion through heat; the fact that the moisture goes first to the younger parts and the buds speaks against it: "Nature does not build up things of such importance upon so changeable and uncertain a basis."

Hence Wolff constructs a peculiar vital force which he calls vis essentialis: this force is endowed with qualities corresponding to the work required; "it is sufficient for the purpose in view," "in any case it produces the effects in question."

Similar inferences can be drawn from the study of animal development so greatly advanced by Wolff. The main problem is : how does the nutritive matter of the egg pass into the embryo? This happens not through a contraction of the heart or of the vessels, nor through a compression of the heart by means of an outer contraction of the muscles, for at first the heart is not connected with the arteries and does not even beat; nor are there any preformed canals to be found. So there is again a peculiar force, a "vis essentialis," at work; it directs the epigenesis, as later on it will direct the conservation of the mature body.

Of great interest is Wolff's idea that his "vis essentialis " can unite in a common work with the agents of the inorganic, and the way in which this is imagined: there again we see him proceeding entirely like a modern.

The main point first of all is the greater or less "tenacity" and "capacity for solidification" of the parts directed by the new force; and this force itself can be weaker or stronger; on the whole quite 
a number of "accessory principles" can be added to the vital principle, for it is "clear, that with the formation of the organic a body in general is also formed, and this body is constituted an organic body through special additional influences."

An organic body requires "influences" from outside, as, for instance, the addition of nourishment. But we must remember that "those processes whose removal causes the cessation of life cannot be described as vital processes;" any more than the thread which supports a sword over a man's head is a vital process.

We may therefore sum up the results, and answer our main question: "the bodies implied in development are not machines." "We must carefully distinguish the growing substance from the machine which envelops it. But the machine must be regarded as its product."

Yet the developing substance works "as far as it is endowed with certain qualities," not " as far as it is constructed in a certain way." "Only accessory" is every event in the organism which is determined by its composition. It may influence or modify "but it does not belong to the causes which determine the development." Here we have a static or tectonic teleology expressly rejected in favour of a dynamic teleology, of a Vitalism ; and it could not be done in more simple language.

Wolff then reaches a short settlement with his opponents and with those whose views resemble his own.

It cannot surprise us that he calls "mechanical medicine" an "imaginary system," one, that is, to 
which nothing in the nature of things corresponds. Much of course is executed by the machine, as, for instance, the circulation of blood, breathing, excretion, and mastication; but these mechanical events are only a "small appendage of the animal," and are to be distinguished from the animal itself.

Wolff thinks his view related to those of the botanist Ludwig, and of Harvey and Needham the chief representatives of an epigenetic Vitalism, though he calls the latter's book " intolerably confused," and though he admits that they all (apart from Harrey's curious "conception-theory") do not go beyond the most general theses established by Aristotle-that there is a generating power in nature. $\mathrm{He}$ appears to consider that his theory resembles most closely that of Stahl.

This remark appears strange, when we remember that Stahl speaks clearly about the operations of the rational soul; and we might doubt whether Wolff knew Stahl's work directly or only through hearsay. He does not give any particulars, and never once mentions even the title. ${ }^{1}$

Wolff concludes his book with an idea which sounds not less modern than that with which he began it: he had " not explained anything" in respect of the effects whose mechanical nature he denies. He had only "investigated the connexion which exists between machine and life," but " had not investigated any further the causes of the

1 Dr. Stenta in his Italian translation of this work, has brought forward evidence (pp. 379-383) which tends to show that Wolff may after all not have regarded Stahl's views as so similar to his own.-Trans. 
latter where it has no relation to machine." This at once recalls the language of Mach.

If we consider all that has been said, we find that Wolff is the clearest and deepest representative of Vitalism since Aristotle; he at least tries to prove, though certainly his proofs are open to objection. $\mathrm{He}$ possesses great knowledge, great philosophical training; he does not talk of what he does not know; he is not satisfied with pseudo-solutions. His theory is not so all-embracing as that of Stahl : and hence it is more important biologically.

(iv) BONNET. HALLER.

We have already mentioned that Swammerdam is the real originator of the idea of evolution in the sense defined above : but in Bonnet and Haller we have two of the thinkers whose work was of outstanding importance for the completion of the theory. All evolutionists are, by the nature of things, strenuous advocates of a static teleology, of a tectonic foundation for the purposive. For them Vitalism plays only a secondary part. They are therefore of less importance for our purpose, and we cannot devote so much space to their views as we did to those of the supporters of epigenesis.

Charles Bonnet has chiefly explained his views in his work Considérations sur les corps organisés (Amsterdam, 1762). ${ }^{1}$ The real reason why he crossed over into the evolutionist camp must have been his

${ }^{1}$ C. O. Whitman's splendid monograph on Bonnet's teaching may be recommended here: "Bonnet's Theory of Evolution. A System of Negations." Both this and the same author's "The Palingenesia and the Germ Doctrine of Bonnet" may be found in the Biological Lectures, Woods Hall, for 1894. Boston, 1895. 
discovery of the parthenogenetic development of plantlice: there are, in fact, several generations in series lying hidden one within another, for the eggs of embryos already begin to develop: and here nature presents to the eye that very "emboittement" demanded by theory.

"Il n'est point dans la nature de véritable génération ; mais nous nommons improprement Génération le commencement d'un développement qui nous rend visible ce que nous ne pouvions auparavant apercevoir." The essence of the whole theory of evolution is expressed in these words; with good right has C. F. Wolff called it a negation, not an explanation of development.

Bonnet, the "Ovulist," lays particular stress on the fact that the germ must exist in the egg as a perfectly formed being before fertilisation; and he is critical enough to admit that the theory would break down if the opposite were proved. But this opposite is not proved: "il est démontré que le Poulet existe dans l'œuf avant la Fécondation."

Certainly no exact pre-existence of all proportions of the germ must be supposed: "Tandis que le Poulet est encore dans l'état de Germe, toutes ses Parties ont des formes, des proportions, des situations qui diffèrent extrêmement de celles que l'Evolution leur fera revêtir. Cela va au point, que si nous pouvions voir ce Germe en grand, tel qu'il est en petit, il nous seroit impossible de le reconnoître pour un Poulet"; and for mammals and man the same holds good. ${ }^{1}$

1 " L'homme et les Quadrupèdes, dans l'état de Germe, ont sans doute aussi des formes et des situations qui ne ressemblent nullement à celles qu'ils acquierrent par le développement." 
In any case, alterations of form bears only on the external : the essential is extended only during the course of "development." Bonnet says in one place that the germ possesses only the character of species but not of individual ; it is $a$ horse but not this horse.

Not even a finger ought to be accepted as a real new formation; this he had said before Haller, who repeats it though he was as yet a believer in epigenesis. We may be misled into imagining the existence of a new formation because the different parts develop with different degrees of rapidity.

Bonnet hardly thinks it worth while to enter into discussions with his opponents; Buffon's views are discussed with a brief and sweeping characterisation as " des songes qui ne sont pas même philosophiques."

This is not the place to discuss the cosmic views found in Bonnet's Palingénésie :

"Toutes les pièces de l'Univers sont donc Contemporaines. La Volonté Efficace a réalisé par un seul acte tout ce qui pouvait l'être."

Its chief idea is that there is really no new formation in nature. The details may be learned from Whitman, who also deals with Bonnet's views regarding the relations subsisting between the theory of evolution and the idea of resurrection. ${ }^{1} \mathrm{We}$ hear of the various kinds of germs required by the soul for the pre-Adamic, the present, and the future world; everything is treated on the analogy of the metamorphosis of insects. There are also hints of

${ }^{1}$ The belief in resurrection seems to have been the psycho. logical starting point of the whole of Bonnet's theoretical work. 
theory of descent (preformed of course): monkeys will perhaps one day generate the Newtons and Leibnitzes, beavers the Vaubans.

It is more to our purpose instead of wasting time on such phantasies to examine in greater detail the way in which Bonnet conceived the process of development through extension; but what we are told is only that the germ has very narrow meshes between its simple parts, and that later on foreign elements introduced by the process of nutrition extend these meshes. "Le Germe n'est, pour ainsi dire, composé que d'une suite de points, qui formeront dans la suite des lignes."

Though Bonnet evades many a difficulty, he never neglected the task of throwing light on at any rate the most important obscurities in his theory that came to his notice. The results of experiments on regeneration must have caused special doubts-Trembley's experiments on Hydra, for instance: here it is said that Hydra is merely a repetition of numerous minute polyp-germs, which are only waiting for favourable circumstances in order to develop. Only the question where the souls for the many polyp-buds would come from seems really difficult to Bonnet. He allows only germs of complete organisms to serve as explanation for processes of real regeneration and, not like Weismann in recent years, of parts of the organism ; the preformed complete germs are arranged in such a way that they extend themselves in each particular case only so far as to replace the part that is lacking.

Thus Bonnet makes no use of active vital forces 
of any kind-at any rate he believes that he does not need any. A given structure, combined with very simple modes of action, effects everything. Hence Bonnet is not a Vitalist. For the rest it is very odd how he sees no other solution than either tectonic teleology, or a wild sort of mechanical epigenesis. He does not perceive the possibility of an enlightened Vitalism in some such sense as Wolff's.

It may perhaps be objected that an investigator whose work makes so much use of soul as Bonnet ought to be designated as Vitalist. But we can make the general answer, as often before, by indicating that the soul (corresponding to Aristotle's voûs) is regarded by all thinkers in an age when the theory of knowledge was still so confused, as something not belonging to nature. The soul is a counterpart of nature, not a part of it; both are apprehended as absolute realities. Here we see the great influence of the philosophy of Descartes and Leibnitz.

Swammerdam was the first to announce, and Bonnet the founder of, the theory of evolution; but Haller is its real systematiser.

Albert Haller (1708-1777), the well-known savant and poet, can best serve as the typical representative of the theory of preformation; almost the whole of the eighth volume of his comprehensive Elementa Physiologiae corporis humani ${ }^{1}$ is devoted to it and to discussions of a general nature. But we do not find with him such a profound exposition or such

${ }^{1}$ Bern, 1766 : I write Albert, not Albrecht, as Haller himself says "Albertus" in the title of the book. 
an effort for clearness, as with Bonnet. Everything is treated more dogmatically, although not in Stahl's way. Perhaps it is to this very circumstance, perhaps also his authoritative position as professor, that we must attribute his influence.

But even if Haller does not appear to us an entirely original thinker, it would yet be a great mistake to see in him the short-sighted fanatic depicted in historical sketches of the materialist Darwinian school. Already $H i$ is has rightly emphasised this. When condemning Haller it is usual to refer to a rather superficial poem by Goethe: but it is at least doubtful if it is not possible to distinguish something like the "kernel" and the "shell" in nature, and if he who sees only the shell ought not to be described as the more fortunate. In any case, Haller was not less misrepresented than Wolff when his chief concern, his Vitalism, his rejection of the machine-theory, was (one is tempted to say) caenogenetically suppressed.

No thinker of that time paid so much attention to the riews of his opponents as Haller; in perfectly conscious opposition to these views (which failed to convince him) he became an erolutionist : for, as we remarked above, he began as an adherent of the epigenetic school.

Haller seeks to present actual facts, and rejects hypothesis in an almost Newtonian manner: "Hypothesin nullam admisi," "Hypotheseos neque umbra subest." No shadow of an hypothesis should therefore be found in his works, but in point of fact the wish is very far from being realised. 
His objection to Wolff's "vis essentialis" 1 is that it gives no answer to the question why in any given species that force maintains the type, and on the other hand creates so many different types; whereas the inorganic matter can take any possible shape. We shall certainly reply to Haller that in all branches of natural science there is much that must be simply accepted, and that his objection can be well turned against himself.

Buffon, moreover, he says, knows so little about his "modulus interior," that some people have already said that a seventh sense is needed to understand him. ${ }^{2}$

But blind powers cannot, as Cartesians and mechanists wish, create anything harmonious out of disharmony, -an assertion which Descartes at any rate, to whom nature was something ordered once and for all, could hardly have made.

The organising activity of Stahl's "soul," as a purely conscious spiritual power, is only poorly proved through " monstra" and the like.

The one remaining possibility is that the embryo is already there when conception takes place. ${ }^{3}$

1 "Cur vis ea essentialis, quae sit unica, tam diversas in animale partes semper eodem loco, semper ad eundem archetypum struit, si materies inorganica mutabilis ot ad omnem figuram recipiendam apta est ? Nulla datur responsio."

2 " Et primum, quid sit modulus interior ? adeo non intelligunt clarissimi viri, ut ipsi fateantur, septimo sensu nos egere, ut intelligamus." Very much to the point is the objection urged against Buffon that full grown animals of ten no longer possess such organs (e.g. larval organs in the case of frogs and insects) or do not yet possess them (e.g. the beard)-and nevertheless they are inherited.

3 "Superest id unicum ut fetus structus et fabricatus sit, quando conceptio accessit." 
"Nulla est epigenesis" : there is no new formation.

In this way Haller accepts Bonnet's views: God has created all structures; they do not develop but only grow; no one part is built before another: are all there simultaneously: "Nulla igitur in corpore animali pars ante aliam facta est et omnes simul creatae existunt."

The subject of the hydra and the phenomena of regeneration Haller disposes of similarly to Bonnet: only the part taken by the male element which appears to be superfluous gives him some difficulty : it probably contributes to the growth of certain parts. ${ }^{1}$ We cannot here consider his disquisitions about the formation of hybrids, which are of course entirely hypothetical.

Everything is thus settled : if the fetus is already enclosed in the egg and only nourishment is needed to make it grow, then we have solved the paramount difficulty of the construction of a highly artificial fabric out of raw matter. ${ }^{2}$

Matter, then, ordered but invisible, develops into matter ordered and visible ${ }^{3}$ this must be so, and the fact that some people do not observe it proves nothing.

1 "Spero ostensurum me, esse in semine masculo vim, quae certarum partium corporis animalis incrementum promoveat et tamen fundamentum futuri animalis a matre esse."

2 " Si in matre est primordium fetus, si id structum in ovo est et hactenus perfectum ut unice recepto alimento egeat, ex quo convalescat, soluta est illa summa difficultas artificiosissimae fabricae ex bruta materia struendae."

3 " Si viscera paulatim de statu invisibili prodire visa sunt, non ex bruta materie in conspicuam, sed ex male limitata in melius terminatam transiisse adnotavi." 
Again we have the clearest expression of a machine theory, of a static teleology-of anything but Vitalism : and naturally enough, since Haller fails to enlighten us with regard to those factors determining growth which he, too, is of course forced to assume. It remains obscure how far Haller meant to indicate something of the nature of autonomous forces in those physiological principles-especially irritability ${ }^{\mathbf{1}}$ and contractability, which, though not originated by him, are very thoroughly discussed in his works; they could only serve as general connecting concepts.

We are not here called upon to deal with Spallanzani, the prominent experimenter, who put forward no original theory, following Bonnet and Haller in all general questions ; and the same applies to many other writers of repute.

\section{(v) BLUMENBACH.}

With J. F. Blumenbach (1752-1840) the old Vitalism reaches its height, and with him this second period on which we are entering comes to an end. The third stage which follows Kant and the Naturephilosophy produced no work to rival the lucidity of Blumenbach's exposition.

Blumenbach profits by all the good qualities of his predecessors and avoids their errors; coming at the end of the fierce strife about epigenesis and evolution, and subjecting all the arguments on both sides to a comprehensive critique, he learnt one quite definite lesson of controversy-that it was essential to reflect once more with an open mind

1 This principle is due to Glisson (1596-1677). 
on the actual biological data. He thus reaches something which at least looks like a real "proof," and thus eventually takes a step beyond the point reached by Aristotle.

Blumenbach expounded his views in two works of no great length : the Institutiones physiologicae (Göttingen, 1787) and the work Über den Bildungstrieb (Göttingen, 1789). The latter, by the way, is the first work in German in this field. The Institutiones give us a good opportunity of examining more closely Haller's theory of the fundamental physiological functions which we have already had occasion to mention.

Under "vires vitales" Blumenbach enumerates in the usual way Contractability, Irritability, Sensibility : they are the fundamental physiological phenomena, which, together with the "vita propria," the specific vital activity of the parts, condition the work of the functions.

Blumenbach, like Haller, does not say more about the nature of these powers, and it remains undecided whether he saw there an autonomy of vital activities or not.

Besides the above forces we have another formative force-the "nisus formativus" - directing morphogenesis, conserving the organic form by means of nutriment, and restoring it after mutilation; it is a power peculiar to living bodies: "peculiaris vis corporibus organicis vivis connata et quamdiu vivunt perpetuo actua et efficax." It is called "nisus" because it is logically subordinated to the "vires," to the forces in a general sense, as one "vis vitalis" among others. 
All this is very briefly treated : and there is also a very brief semblance of a proof of these statements to be found in the assertion that the formative impulse first comes into being after the mingling of the sex-liquids ${ }^{1}$ in the uterus; hence the embryo becomes visible, "in spite of the perfection of our modern optical instruments," only during the third week.

This is not a particularly valuable contribution. Of greater importance are two methodological remarks in the Institutiones: in the first place a certain relation is affirmed between the nisus and other nature-agents, on which the figures of Lichtenberg and the crystals are based ; and secondly, we have the important assertion that the " nisus formativus" is less a cause than an "effectus quidam perpetuus sibique semper similis" ; it expresses an effect ever recurring and ever like itself, and it is in this sense and in no other that the words " gravitation" and "attraction" should be used.

This view is not only borne out by the facts, but is greatly in advance of contemporary thought at any rate in biology.

We find in Blumenbach's work, Über den Bildungstrieb, an amplified treatment of all the problems which in the Institutiones were merely outlined : we have in fact a real system of Vitalism.

The treatise contains a good introductory historical sketch; then comes a note on the author's

${ }^{1}$ According to Blumenbach the spermatozoa are only "little worms in stagnant liquid." Their unimportant nature can be seen by the fact that in animals which resemble one another the spermatozoa are often very different, while in animals which differ widely they are often almost identical. 
omp position, that be fimself bad formedy been an adberent of erolution. and had consequently gone through a process of development directly opposite to that of Haller. So this bouts contains "- the cunfession of his own errors" "; but " a corrected error oftem becomes a truth far more important than many a poeitive trutb direstly revognised as such $=$ (De Lac).

Blumenbuch then repeats the definition of the formstive impulse alreaty given; be emphasikes again that this principle stands by the side of the " otber kinds of vital torce" and nest to the " general phrsicul forces of nature." There follows a furtber explacation of that admirable metbodological observation with regard to the parallel between focmstire impulse and gravity. Both should serve to denote wothing else but the defintion of a force whoke constant etfect bas been reougnised through experience; but whose cause, like the casse of the generally recognised powers of nature, is for us a "- qualitas overtio."

We cannot insist enough on the ralue of this critical passige. If ouly all Vitalists bad been conscious of the netessity of similar exactitude there would bare been no nerd for the later criticisms and rejections of the theory by a Lotue or a Clacde Bermird-justiffed as that criticism may hare been in rien of the actual sitcation.

To emphasise the quality of Blumembach" s insight, we bare only to remember bow these same laws were conceived by his contemporary. I. Biclat (1\%1.18y?, wto did Talusble work in histology and pachology. Bichat, who died young, sup- 
ported a vitalistic theory, which it may be observed he failed to prove, and which was in no way based on the facts of morphogenesis. He also claimed to place his "propriétés vitales" on the same lerel as "gravité, élasticité," etc. Here is a passage taken in extenso from the first volume of his Anatomie générale, ${ }^{1}$ which will best show the contrast :

"Les lois physiques sont constantes, invariables; elles ne sont sujettes ni à augmenter ni à diminuer. Dans aucun cas une pierre ne gravite arec plus de force vers la terre qu'à l'ordinaire." "La formule étant une fois trouvée, il ne s'agit que d'en faire l'application à tous les cas." ... "Au contraire, à chaque instant la sensibilité, la contractilité s'exaltent, s'abaissent et s'altèrent; elles ne sont presque jamais les mêmes." "Toutes les fonctions vitales sont susceptibles d'une foule de variétés. Elles sortent fréquemment de leur degré naturel (!) : elles échappent à toute espèce de calcul ; il faudroit presque autant de formules, que de cas qui se présentent. On ne peut rien préroir, rien prédire, rien calculer, dans leurs phénomènes. Que deviendroit de monde, si les lois physiques étoient sujettes aux mêmes agitations, aux mêmes variations que lois vitales?"

A peculiar idea of the essence of natural law.

And yet Bichat makes many valuable contributions, as for instance his separation of the "propriétés vitales" from the "propriétés de tissu"; the latter are conditioned only by structure and in conjunction with the former produce the "vita

${ }^{1}$ Paris, 1S01. Compare also Pecherches physiologiques sur la vie et la mort, fourth edition, Paris, 1522. 
propria." There is also his description of animal chemistry as "l'anatomie cadavérique des fluides" and its exclusion from true physiology; and his demand that science shall "remonter des phénomènes aux principes, et ne pas descendre des principes aux phénomènes," etc.

But Bichat's writings display a lack of that essential methodological principle, the recognition of the absolute rigidity of natural law in vital phenomena: and it is precisely when contrasted with a biologist whose service to science is so universally admitted that Blumenbach's importance is most clearly brought into relief.

Returning then to the German thinker. A brief reference not entirely to the point is made to Wolff, whose " vis essentialis " really only supplies nutritive matter, and thus is only "a requisite" of the formative impulse. ${ }^{1}$ It is followed by a section on his adversary Haller, couched in terms of the greatest respect. Blumenbach then passes to the proofs of his own theory. The following phenomena speak against "preformation" and for "epigenesis" : of primary importance are the galls; then the formation of new blood-ressels round encapsuled tumours and foreign matter; thirdly, the formation of new joints after fractures; further, the appearance of hybrids, which evolutionists recognise as a difficulty for their theory; finally, simple observation. During the course of development new formations are still taking place, and these are con-

${ }^{1}$ It comes into evidence, however, in the case of tumours; on the other hand it is not found in instances of bad nourishment, in spite of the presence of a formative impulse. Here Blumenbach obviously misunderstands Wolff. 
tained, as form, in the germ as little as the arbor Dianae in silver-amalgam.

Blumenbach refers particularly to the history of the development of algae and the buds of Hydra.

To be quite strict, these things prove only epigenesis, not vital autonomy, as our author imagines. The conception of the formative impulse of growth, the conception of the inner structure is foreign to him ; as a real proof for Vitalism we must adduce the fact that formation of organism cannot be understood at all on the ground of a given minute structure whose parts influence each other. Blumenbach's proofs, however, were the best at his disposal in that age.

His theory is rendered the more profound by notes on "reproduction," i.e. restitution in our terminology: the new matter arises out of the old, as with Hydra the regenerating stem becomes smaller; the same is true in the healing of large wounds. An attempt had been made to solve the difficulty by assuming pre-existing germs, but that is unsatisfactory with phenomena of grafting or when a Hydra, which has been slit from top to bottom, closes itself by rolling up the edges of the wound, or by forming a new digestive cavity.

We must strictly differentiate that kind of reproduction where new matter is produced, from that where "only the disturbed formation has to be rebuilt" : a reproduction which must be differentiated and separated from the others the more carefully, the less they can be compared with the hypothetical germs, and the greater the predominance which they give to the theory of a formative impulse. 
We might imagine here that we were listening to a debate on phrsiology of derelopment in the nineties of the last century. Blumenbach is prior both to Roux and to the author of this book in a very important matter: namely, in the establishment of the conception of restitution that is not true " regulation." 1

And then comes a thought for which Blumenbach can claim priority orer Gustar Wolff. How, he asks, can everything be preformed in healing and similar phenomena in view of their casual nature? "It would be presumptuous to try to persuade anyone of such a thing." Such is in its clearest form the conception of "primary purposireness," which is used both by Blumenbach and G. Wolff against preformation and in farour of the ritalistic theory.

Compared with the abore the details which Blumenbach gives as to the mode of action of his formative impulse are naturally of a rery indefinite and preliminary nature, and of much less importance: and at the most we need record his view that eren malformations follow special laws, although here external causes disturb the results of the formative impulse.

Thus we find ourselves at the end of the second period of the old Vitalism and, as we hare already mentioned, at its height. If we compare the beginning and the end of this period, i.e. Harver and Stahl on one hand and C. Fr. Wolff and Blumen-

1 Under "Regeneration" we only understand the separation of damaged parts by "sprouting " from the wounded surface. 
bach on the other, we are struck by one thing : biology, which used to be an appendage of philosophy, borrowing its principles ready from existing philosophical dogmas (and almost all philosophy was dogmatic then)-biology changes into a science, clearly and firmly based. Only now, at the end of the second period, do we get beyond the achievements of Aristotle. This is due to C. Fr. Wolffand above all to Blumenbach. 


\section{(d) KANT-CRITIQUE OF JUDGMENT.}

THE task we have set before us is not to write a history of philosophy, nor eren to indicate in the systems of various philosophers what this one or that may have thought about biological questions. Only when a philosophical doctrine has exercised a lasting influence upon the current Biology have we briefly drawn attention to it. This occurred first. with regard to the teaching of Descartes; the second case of it will be in connexion with the theories of the Nature-Philosophers and of Schopenhauer.

If we make an exception in the case of Kant, and analyse his Critique of Judgment with particular thoroughness, our reason will be the extraordinary and far-reaching influence which this book has exerted up to the present day. It is not that I imagine any too many of our modern scientists to have read Kant's works ; I know, on the contrary, that only too few have done so. But everyone has heard about them from someone else, who also has heard about them; and so ereryone expresses his opinion on the subject. It is time that an abuse so unworthy of modern thought was stopped, and we hope to contribute at least something towards its remedy. 
In itself and apart from its fundamental and unique significance, Kant's work would not require such a close analysis in a book devoted to the history of scientific doctrine. We may indeed preface our whole treatment of the work by emphasising the following important consideration : it would be a great mistake to suppose that the object which Kant had in view in writing his Critique of Judgment was the analysis of biological questions. Nor yet was it the real aim of his book to establish the proposition (complementary to his Critique of Reason) that the existence of a personal Creator is not a valid inference from the purposiveness of nature.

At the beginning and at the end of the book it is clearly stated what Kant's real intention was :-The world of nature and the world of freedom are two separate worlds, which in themselves have no influence upon each other; but the world of freedom is meant, especially in human moral activities, to gain influence over the other world. Hence nature must be so conceived as to make this possible. There must be a reason for the unity of the Supersensual which is at the basis of nature and of the concept of freedom. This reason, or ground, is the notion of design.

The object of the Critique is therefore ethical, not scientific.

Man as noumenon is free. In this moral capacity he is the highest purpose. His causality alone is teleological in the world. At the same time, however, the law by which he determines purposes is conceived by him as independent of natural conditions and yet as necessary. 
Teleology then must reconcile nature and morality.

What this means-whether it is possible at all, and whether it is possible in this Kantian formwith these questions we have in this book absolutely no concern ; but we must know what was Kant's intention if we do not wish entirely to misjudge his exposition.

A distinguished authority ${ }^{1}$ has characterised Kant's Critique of Judgment as the best of his works. We do not wish to correct this judgment in so far as the work as a whole is considered in relation to the Kantian system. But where the contents of the third Critique concern us more nearly. with regard to the specific development of a Critique of teleological Judgment, we cannot join in the above praise.

The exposition of this theme is widely removed from the clearness of the Critique of Reason. especially compared with the first half of the earlier work. Perpetual repetitions, due in part to a peculiar architechnic rigidity, weary the reader without clarifying the exposition. The final conclusion with regard to the biological problem itself remains doubtful, or at any rate is not quite unambiguously established. Hence, representatives of completely different biological views have been able to construe Kant's book to their own advantage for the most part, as we have said abore, without any very thorough examination of his teaching.-

Judgment is the faculty of thinking, the particular as contained under the universal. Judgment is

${ }^{1} \mathrm{~W}$. Windelband. Immanuel Kant und seine Weltanschauung, Heidelberg, 1904. 
determining when we subsume under the given universal ; it is reflecting when we seek the universal for the given particular. If the sum of the data of external experience is to be submitted to the reflecting judgment, then we shall require a principle which is not borrowed from experience, but which is supplied by the reflecting judgment itself. Now there is one such principle, and it declares that nature is to be regarded from the point of view of a unity as if an understanding had adapted it to our powers of cognition. But this implies a law only for the reflecting judgment, not for nature.

Purpose is the concept of an Object in so far as it also contains the ground of the actuality of the Object. Purposiveness of the form of a thing is its agreement with that constitution of things which is only possible according to purposes. The purposiveness of nature is therefore that principle of the reflecting judgment : and it is a transcendental principle. ${ }^{1}$

The maxims-Nature takes the shortest way (lex parsimoniae); at the same time it makes no leaps (lex continui); its great variety in empirical laws is yet unity under a few principles, etc. ; are illustrations ${ }^{2}$ of what has been said. In all these cases it is not stated how we do judge, but how we ought to judge.

A sharp distinction must be drawn between the general laws of the uniformity of nature which are

1 Hence no Category.

${ }^{2}$ The first example clearly has a different character from the other two : it relates to causality, to the law of change, while the two last relate to the tectonic of nature. Kant himself, as our exposition will shortly prove, draws this distinction. 
known a priori, and the specification of those laws according to the principle of purposiveness. According to what has been said, the variety of nature corresponds to our requirements in respect to its tectonic, not in respect to its general laws; hence, it is the discovery of the former, not the knowledge of the latter, which is the ground of pleasure. ${ }^{1}$

The aesthetic judgment judges formal purposiveness by the feelings of pleasure and pain; the teleological judgment judges real purposiveness through understanding and reason. The first judges by a rule, but not by concepts; the second is the reflective judgment in general, and judges, like all knowledge, by concepts, but only in respect of certain objects of nature according to special principles. ${ }^{2}$

So much for the introductory explanations. Then follows the critique of the aesthetic judgment, which does not concern us. It is followed by the Critique of the Teleological Judgment-first of all as "Analytic."

The Analytic begins by rejecting once again the categorical nature of purpose. There is in the general idea of nature no a priori reason why objects of nature should be related to each other as means and end, nor why its possibility is comprehensible only by means of this causality. Teleology is only problematically and by analogy brought to bear on the investigation of nature without any pretence to

1 The later Philosophy of Nature proceeds from the concept of the "Tectonic of nature."

${ }^{2}$ Once more therefore: Teleology is according to Kant not a category. 
explain it, i.e. only in the sense of reflective judgment. Thus we have at least a rule as a principle where causality, as we shall point out more in detail, does not suffice.

Teleology is thus only a regulative principle of judgment; to regard it as a constitutive principle would mean "introducing into natural science a new causality which we borrow from ourselves alone, and yet attribute to other beings-whom, however, we at the same time refuse to regard as like ourselves."

Here we have the first passage in Kant's work which is of biological importance, and it must be admitted that it is somewhat obscure. The point at issue here is not, however, to what in particular in nature the conception of purpose may be presumed to apply; so that it is not yet made clear how far a new causality would be introduced by allowing purposiveness to be a constitutive principle either as creation or as a mode of causality within nature. One thing, however, is clearly laid down-that we borrow this new causality from ourselves. Since, however, "we" belong to nature, then somewhere and somehow this new causality does exist in nature.

These remarks are only to secure our attention, and we now advance a step further.

After a brief treatment of objective but merely formal purposiveness, as for instance that of certain geometrical figures in the solution of problems, Kant proceeds to deal in order with the following subjects: The relative Purposiveness in Nature, Things as ends of Nature, and Nature as a system of ends. 
We can speak of objective and material purposiveness only when there is before us a relation of cause and effect "which we find ourselves able to apprehend as legitimate only in this-that we introduce the Idea of the effect into the causality of the cause as the fundamental condition of the possibility of the effect." Now, such purposireness is relative when it is merely a means to some other end as, for instance, rirer mud to plants. In such a case the effect can quite well be understood from the cause without reference to teleology. We are dealing here with "accidental" purposireness, mere " advantage" to one thing through another which, of course, has significance only when the existence of that to which the advantage accrues is itself a real end of nature. The relatire purposireness of the sexes is the only instance of any deeper importance.

At this point I should like to insist that relative purposiveness can be of great significance. For it appears to us that the problem is more closely connected with that of "Nature as a system of Ends" than Kant seems to assume.

Now a thing is inconceivable through the mechanism of nature. We are therefore obliged to introduce a cause whose possibility of efficiency is determined by concepts, in a case where the form of the thing is not possible by means of the laws of nature alone (i.e. of laws which, applied to sensible objects, can be cognised by the understanding alone), but when "concepts of Reason" come into play. The form of such a thing appears to be causally contingent.

Kant now seeks for an example of this. It would occur, for instance, if one were to discorer the 
drawing of a mathematical figure in a desert. The chances against meeting with such a thing would be so infinitely great that it would be "just as if no law of nature were capable of accounting for it" : and one would exclaim " vestigium hominis video." 1 The question would be that of an art product.

We have an "End of nature" when a thing is (though in a double sense) both cause and effect of itself. Kant then explains this by a description of what we now call embryology or ontogeny, and then passes on to a minute analysis :

For a thing to be an end of nature it must be only in relation to the whole that its parts are possible, and the parts must be reciprocally cause and effect of each other's form. The idea of the whole must determine the form and connexion of all the parts, "not as a cause-for then it would be an artificial product-but as the ground of cognition for him who is judging it of the systematic unity and combination of all the manifold contained in the given material."

It seems fitting to interpolate here the remark that in the sense of a purely descriptive Teleology, which takes no account of the laws of nature controlling natural purposes, Kant's idea may most advantageously be considered as an endeavour to discover some characteristic of natural objects

1 Bütschli (Verb. Nat. Med. Verein Heidelbery, 7, 1904) has rightly, as I think, objected to the "vestigium hominis video" that solidified gelatinous solutions also give us regular geometrical figures. He need merely have referred to snow flake. On the other hand, we must remember that such figures even if they no longer are possible only by means of art, are still grouped under natural purposes. All crystalline phenomena are thus to be considered as not only chemico-physical. 
which necessitates the introduction of a judgment of the teleological kind and of the teleological kind alone.

Kant now discusses at greater length the differences between artefacts and natural purposes. In the case of the artefact the producing cause lies not in the nature of the material, but in a being which can produce effects according to ideas. Thus the artefact, if it is a machine, has merely moving power; but the organism has in addition formative power. Thus organised nature is no "analogon of art."-at any rate that would be saying too little. It is rather "analogon of life." But in such a conception we must either endow matter as mere matter with an attribute which is opposed to its rery nature (Hylozoism) or couple with it a foreign principle, a soul. In this last case the possible alternatives are to give the soul already organised matter as a tool, which explains nothing, or to make the soul the artificer of this structure, and thus remore the product from (corporeal) nature.

To be quite exact, then, says Kant, the organisation of nature has in it nothing analogous with any sort of causality which we know-and this in spite of the fact that man acting according to teleological causality belongs to nature in the widest sense.

Natural purposes therefore cannot be explained by any causality of nature in its widest sense. The concept of a natural purpose is always and only regulative for the reflective judgment. We always speak "as though" there were something, but do not wish to introduce a specia] ground of causality, or to set up any "master-builder " over it all. 
Here ends the discussion about things as "ends of nature," and it will, I think, be granted that it is in a high degree unsatisfactory for biological questions proper.

It might seem at first as though Kant sought to make clear the logical nature of judgments of the descriptive-teleological kind only. But Kant does not here treat biological matters in an exclusively descriptive-teleological manner, since he includes man in nature, and allows him, in reference to his activity, to be subject to elementary laws of a teleological kind, though he does not actually adduce any analytic proof for the same. Man is, however, a living being, so that for certain phenomena in certain living beings Kant is a "Vitalist" according to our definition, whether he draws the conclusion himself or not.

After this introductory examination we wonder why our philosopher rejects the possibility of a universal knowledge of the mode of causality in the organic.

The statement that organic nature is " an analogon of life " rather than "an analogon of art" where it is precisely life which is being examined, seems at first very obscure. Then we find in the Metaphysical Principles of Science the following definition: As opposed to the inertia of matter which implies lifelessness, Life means the power of a substance to determine on activity by an inner principle-the power of a finite substance to determine on change, of a material substance to determine on movement or rest as a change of its state. The only recognised principle of change of a substance is 
desire, and the only known inner activity is thought; these grounds of determination are, however, not "representations of the outer senses" and therefore not "determinations of matter as matter." Thus, according to Kant, all matter as such is lifeless ; this and no more is what the law of the inertia of matter says.

If we consider the sense of these words with reference to the discussion of natural purposes, then the latter might be understood to mean that organised nature is no analogon of art, inasmuch as it is not organised by something outside itself, is not created; it is rather an analogon of life in the sense of that human activity which alone is known to us as a fundamental law, and which rests upon desire and thought as internal factors. This conception makes it clear that matter as mere matter cannot "live," at least not in this (the hylozoistical) sense, and renders untenable all subsequent life-stuff theories with which we shall be concerned. ${ }^{1}$ On the other hand it is not clear why by coupling with matter a foreign principle as the artificer of the structure, i.e. of organised nature, the product would be removed from nature; for it is on the ground of this supposed result that Kant rejects any sort of Vitalism.

Yet he has expressly associated man as an active being with nature : and man, he admits, possesses teleological causality.

${ }^{1}$ Cf. the passage in the Dialectic of the Judgment: "But the possibility of a living matter is unthinkable; the concept contains a contradiction, for lifelessness, inertia, is the essential characteristic of matter." Only by a vicious circle, according to Kant, can we deduce purposiveness out of the life of matter. 
Why, then, we would ask in modern phraseology, cannot the organised world be explained, or rather formulated, at least hypothetically after the analogy of this particular, and in the phenomenological sense real, causality?

It will now be recognised, as we said at the beginning, that almost any view could find material to support it in the Critique of Judgment, even though it comprise what Kant rejects. What Kant rejects is : firstly, that organised beings are created machines; secondly, that they derive from a peculiar kind of matter; thirdly, that they are due to particular vitalistic laws. To men, however, he attributes such special laws. From these three negations it would be possible to infer (and the inference would harmonise with his conclusion as regards the whole of the tectonic world) that he reduces organised beings to machines which are merely given and whose origin is not a matter for investigation. In this case he would be a "static teleologist," although the exception made for men would still remain.

But static teleology would still be a positive assertion; something would be affirmed about the nature of the purposive, namely, that it is determined not according to any laws of its own but by a tectonic, though its origin would remain in the dark. With static teleology one of the two alternatives would be affirmed; Vitalism would be denied. But Kant does not wish to assert or to deny anything about the laws or organisation, at any rate not at this point. At the close of the Analytic he expressly describes the concept of an 
end of nature as purely regulative, and this in spite of the fact which must always be emphasised that he reckons men, acting autonomously, as included in nature.

It seems to us that Kant is here to be corrected, and that with regard to organisation we should not be content with such a descriptive, purely " regulative" teleology. For in our view there seems absolutely no reason why between two clearly recognised alternatives of a purely scientific character a decision should not be fixed upon empirically.

But we shall soon come across further obscurities in Kant's treatment in yet another form, and moreover with a somewhat more definite leaning towards Vitalism; and we may turn briefly in conclusion to the considerations on "Nature in general as a system of purposes."

To judge a thing to be on account of its internal form a purpose of nature is something quite different from regarding the existence of the thing as a purpose of nature. To do this last significantly, one would have to have knowledge of the ultimate purpose. But this is lacking. It is therefore impossible to treat the problem at all, and we need only add that naturally things which are not purposes of nature may also belong to a "System of purposes."

With this explanation, which from our biological point of view is of minor importance, the "Analytic of the teleological judgment" comes to an end.

In the Dialectic of the teleological judgment all that has been discussed in the Analytic appears once more, only in another form, and always with the 
conclusion that we are not in a position to prove the existence of a Creator by an argument from design. The antinomies devised for the sake of the schematism of the Critique of Reason are of no greater importance, and we can be even briefer than we were in our discussion of the Analytic.

Above all, it must now be clearly recognised that the realistic element in the Kantian point of view stands out far more clearly in the Critique of $J u d g$ ment, and especially in that section of it which now interests us, than in the Critique of Reason (especially the first edition). Nature is always conceived as a reality (ein Reales) which could be other than what it appears, and which could work in a manner incomprehensible by our understanding. But nature is not, according to Kant, that which is given, or whose laws would be just such as he had formulated, so that "understanding" and "notunderstanding" would not come into the question at all.

We cannot, says Kant, in his realistic vein, "prove" the impossibility of the mechanical production of organisms, because we do not understand the first inner ground of the infinite multiplicity of the particular laws. The productive power of nature may, however, suffice for what we are to judge teleologically just as well as for that which we believe to require merely a mechanical system. That mechanism can afford no explanation, as far as our powers of cognition are concerned, is quite certain.

What is meant by saying that this "power of production in nature will suffice"? Does Kant 
mean that we have here before us an elementary law of nature, but one which cannot be reduced to mere processes of movement? One sees in the Metaphysical Principles that Kant, like the mechanists, requires all physics to be resolved into processes of movement. If we were right, then this passage should be understood in a vitalistic sense : and the opposition of the mechanical character of nature to its achievements through a productive power, seems to confirm such an interpretation. There would be then according to Kant special vital laws (Eigengesetze) which, though subject to causality could not be resolved into forms of motion and were, therefore, in this sense not "explicable."

But does this meaning agree with what has been ascertained above? If this were the case one would be obliged to say that Kant might have expressed his thoughts rather more clearly than is the case. He must then have meant something else ?

We shall not here attempt to settle definitely what Kant really meant, but one thing we may legitimately say, and that is that by introducing two dogmatic principles which led him on to illusory problems, he rendered his task infinitely more difficult, and the solutions of those problems extremely confused. One of the dogmatic principles is Realism, to which we have already referred; the second the Mechanism of Nature as found in the postulate that all physics is to be reduced to mere laws of motion. The fictitious problems arise from the nominal proposal to undertake this analysis for everything in nature. This, according to Kant, is feasible in physics, but obviously not in biology. 
It is our opinion that chemistry, which he also excludes from the sphere of real science, might here have supplied Kant with a compromise : and we shall see later on that Schopenhauer advanced in this direction.

But, after insisting once more that we do not presume to have disposed of all the obscurities in Kant's discussions by our remarks, we must seek to bring our exposition to an end.

There follows the often quoted assertion, that no Newton can ever appear who will explain the production of so much as a blade of grass by laws of nature which no purpose has ordered. To introduce a lighter note for a moment, we may remind ourselves in passing that in the opinion of many authors, though not in his own, Charles Darwin is supposed to have been that Newton; we may further point out that the mention of Newton is very favourable to our view, i.e. that in theorising Kant always presupposed the necessity of resolving all processes of nature into true mechanics.

The obscurity, however, remains that in this passage about Newton: "ordered laws of nature" may be understood to mean a given system of separate laws (static teleology) as well as laws of nature in which order, an ordering element, lies (Vitalism). In our opinion, therefore, owing to his too narrow interpretation of the concept of mechanism (always connected for him with the postulate of reducing all the events of nature to motion, a reduction which is entirely illusory precisely in the case of living beings) Kant cuts himself off from the impartial understanding of biology. It 
is true indeed that to postulate a world-creator as the ground for the purposiveness of the world would be to "proceed quite tautologically"; but it would also, and this is just the view for which the Critique of Reason has prepared the way, be an illegitimate logical procedure. On the other hand, if because we find purposiveness in occurrences in the world we seek to explain this a posteriori by referring to a cause operating according to ends, our procedure is indeed tautological, but legitimate nevertheless.

For in the last resort all explanation is tautology. But Kant, in spite of all his Critique, had not sufficiently grown out of the Cartesian view of nature to appreciate this subtle elaboration of a yet more refined criticism.

Kant, then, might be described as a Vitalist who himself greatly increased the logical difficulties of his doctrine by fictitious problems of his own creation.

Considerations upon the manner in which mechanism and teleology are to be united lead up to the Methodology of the teleological judgment. Such a unification is possible; but does not lead us to substitute one for the other. They are related as end and means; but the law of working (Wirkungsgesetz) of the means requires for itself nothing presupposing a purpose.

Now this sounds once more thoroughly staticallyteleological, and in no wise reminds us of the "productive force of nature"; we are therefore once more in perplexity. In addition to this we read of 
a primordial organisation of the mechanism of nature. But let us proceed.

The general conclusion of the Methodology, viz. that teleology belongs neither to theology nor to science, but only to criticism, and to the Critique of Judgment in particular, concerns us here less than a few corollaries.

After it has been clearly established that the "products and events" of nature must be explained, as far as possible mechanistically, the way in which mechanism and teleology might possibly be unified is examined. "Occasionalism"-the view that the supreme cause of the world would furnish immediately the organic formation on the occasion of every union of intermingling materials-is rejected, as in this case " all nature is lost." The alternative theory, that of Pre-established Harmony, assumes that everything is once and for all preconstructed.

The being produced can now be an "educt," and we get the doctrine of Evolution or individual pre-formation-which Kant rejects.

Or it is a "product" ; this gives the doctrine of Epigenesis, or better of "Generic pre-formation" or "Involution." The specific form is also according to this view pre-formed, but "virtually," viz. in the productive faculty of the generator and in its inner purposive capacity.

Kant adopts Epigenesis : for here propagation, if not the first beginning, is established as self-producing (selbst hervorbringend), and consequently a great deal is left to nature.

Indeed he expressly embraces Blumenbach's 
interpretation. Blumenbach, he declares, begins all explanation of "organised matter" with an "original organisation," and calls the power of matter to fashion itself on the basis of this organisation a formative impulse (Bildungstrieb).

The reader who has carefully followed our analytic exposition of the history of Vitalism will be highly surprised on reading these words.

Kant accepts epigenesis, talks of the "productive faculty of the generation," asserts his agreement with Blumenbach, the Vitalist, and then quotes Blumenbach amiss, i.e. expressly in the sense of a static teleology which rests upon "original organisation," and in words which that writer never used himself.

To sum up everything which has been said in our detailed exposition about Kant's attitude to the fundamental questions of biology, his doctrine may be used in support of the following :

First, of a purely descriptive and exclusively "regulatively judging" teleology which abstains on principle from pressing for any more final explanation : though for this abstention no valid ground is adduced ;

Secondly, of a Vitalism which seems to him doubtful only because he is preoccupied with the dogma of the ultimate reducibility of all natural phenomena to previous phenomena of motion, a postulate which, at any rate in reference to living beings is quite untenable ;

Thirdly, of a static teleology, or the theory of a given structure on the basis of which everything 
happens mechanically. It is true that this view is implied more by the letter than by the spirit of Kant's phrases. An exception is also made, in a vitalistic sense, in the case of man as an active being.

Is it possible to find a satisfactory solution of this strange enigma, a satisfactory reconciliation of what seem at first to be flagrant contradictions in Kant's exposition? By way of an attempt we may put forward the two following considerations.

If we interpret Kant's expressions Organisation and Order not in the sense of an extensive tectonic, of a structure, of a machine, of a juxtaposition of different entities, but only as a specific representation, a given ordering principle, then the statements about Blumenbach, as well as other passages, could be understood in the sense of a pure Vitalism. Blumenbach was, after all, a pronounced Vitalist. That Kant should have materially misunderstood him seems almost impossible. A certain freedom of expression in quoting is, however, not outside the realm of probability in the case of a philosopher who is accustomed in a large measure to construct his own language.

On the other hand, we suggest the possibility of thinking that Kant really did not clearly see the distinction between static and dynamic teleology; that for him teleology not only in its formal but also in its real meaning is to a certain extent one and the same thing, and that in describing it he uses now the terms which characterise one sort, now those which characterise the other sort of teleology. Kant would then be a Vitalist-though not quite 
consistent with himself. If it be remembered that the aim of the Critique of Judgment was chiefly ethical, and that teleology in general was all that therefore really came in for consideration, this view will perhaps gain in probability.

Our final attitude towards the biological content of the Critique of Judgment is therefore as follows. In the case of man and his actions Kant is indubitably a Vitalist, while as regards the facts of organisation he is only problematically so. $\mathrm{He}$ is not indeed always clearly conscious of the logical distinction between static and dynamic teleology, and is dissatisfied with his own Vitalism because it is thoroughly inconsistent with his ideal of what the natural sciences should be. This ideal is the mistaken notion of a rigorous mechanism in which (curiously enough, though we can understand it from an historical point of view) there is room for the activity of souls though not soul-like natural agencies.

Throughout, the general critical discussion of his contention that teleology can have no metaphysical significance proceeds parallel to that of biological problems : but the ultimate object of the whole is neither biological nor metaphysical but ethical.

Our conclusion may appear unsatisfactory; in any case we believe we have shown that any biologist who wishes to appeal to Kant-either in defence of or in opposition to Vitalism-will do well to proceed with some circumspection. 
The above reproduces the contents of the original chapter on Kant. It has, however, occasionally been objected to me in the course of discussion, that I have misunderstood Kant on a rather important point, and the fact of this objection (which may in the meantime have appeared in print), causes me to supplement what I originally wrote by the following remarks. They will not relate to the Kritik der Urteilskraft, but to the two other great Critiques of the philosopher:

I am said to be wrong in asserting that Kant allows the mechanical (in its exact sense) causality of nature to be clearly and indubitably infringed by the intervention of the "soul" of the acting man. This is the reason why (as I said) Kant, at any rate for a limited field of biology, clearly is a Vitalist, a dynamic teleologist : for obviously man is part of living nature. It is replied that the passages cited by me merely refer to man as "noumenon," and his "freedom." But if considered simply as an event of nature, the causality of the acting man is according to Kant also mechanical causality in the most proper sense. Kant is said to subscribe to what is to-day called psycho-physical parallelism.

I do not think that this view is right.

Let us begin by analysing some passages in the Critique of Pure Reason (first edition). 
In the "Paralogism of Simplicity" an attempt is made to show that "simple consciousness" is not " knowledge of the simple nature of our conscious subject in so far as this is thereby distinguished from matter as a composite being." In this connexion it is argued that matter is merely external appearance of whose substratum we can predicate nothing; that this substratum could therefore quite well be simple, though it appears to us as extended and composite ; and further, that it might even have "thoughts." It is true that he goes on: "In this way the same object which in a certain respect is called an extended body would in another respect be a thinking being, etc." But immediately afterwards "hypotheses of that sort" are described as merely allowable for making argument easier. So Kant's own view about the matter which concerns us here is not given in this passage at all; more probably it is that of Leibnitz.

In the general considerations at the end of the "Paralogism" the three possible views about the "communion between body and soul " are critically discussed: the system of "physical influence, of pre-established harmony, and of supernatural assistance." The two latter explanations are in reality only objections to imagined difficulties in the first; but they would be without reason-for the theory of "physical influence" would be metaphysical, and here there would be room for all possibilities, everything in question being absolutely unknowable. It is true that their metaphysical character would be a critical (not a dogmatic) objection against the doctrine of mutual interaction itself. So here again 
we get no factual, but merely a methodical solution. The real question of facts has not even been put, i.e. if it would be sufficient for understanding the changes of what we call nature to suppose a merely mechanical causality.

Let us note in passing, in section 9, iii. of the doctrine of "Antinomy," the proposition: "If all causality in the world of appearance were merely nature ....," and then turn to those parts of the Critique of Pure Reason which are the most important for us. They are entitled "The Possibility of causality through freedom, in conjunction with the general law of natural necessity," and " The explanation of the cosmological idea of freedom in conjunction with the general necessity of nature."

We will not enter into a discussion of the Antinomy between freedom and necessity and its supposed solution. We only ask: does Kant regard his "necessity" as equivalent to a coherent and merely mechanical necessity, or not?

Man has a faculty " which is no object of sensuous intuition," but which "nevertheless can be the cause of phenomena." This causality is in the first sense "intelligible," in the second "sensible" ; in this second sense, as we have already said, "its effect is seen in the phenomenon." It has the character of necessity whose law in any individual case must be found by experience. The intelligible, or "noumenon, begins to act in the world of sense spontaneously" : but this does not imply that "its effects in the world of sense begin spontaneously," for the intelligible is determined for its special way of acting on the world of sense by the same world. 
The doctrine of the "empirical and intelligible character" which follows does not concern us here, as it is ethical and metaphysical. Let us rather ask : is there the smallest sign in all the above that Kant dismisses the intervention of the "soul" in the course of natural events, and that he defends psycho-physical parallelism with its continuous causality in a truly mechanical system ? It appears to me that just the opposite is the case.

Keyserling has tried to establish a general theory of life, a pure Vitalism, in a book ${ }^{1}$ which is a quaint mixture of good and bad, largely influenced by Chamberlain ; he remarks that Kant has occasionally done the same unconsciously. His "freedom" would be a special form of a "law of nature," namely, the form of action of the law of nature which is man; and with reference to his faculty of acting in general not only in relation to morals. One need only extend this principle to the organic in general to get a complete theory of life. I believe that such a view is not only right as an analysis of Kant but also in itself; it has much in common with my own vitalism, of which Keyserling does not speak.

A few words more, however, on Kant.

In the general introduction to the "Analogies of Experience" is to be found the important remark that these analogies (the principles of the constancy of matter, of causality and of mutual reaction) hare no constitutive but merely regulative force. This practically annuls the difference, on which Kant as a rule lays very much stress, between the "Analogies"

${ }^{1}$ Das Gefüge der Welt, Munich, 1906. 
and Teleology, the object of his Critique of Judgment. ${ }^{1}$

In my judgment, as will soon be explained more widely, this would be perfectly right. The whole question is important for the logic of any Vitalism.

From the Critique of Practical Reason some remarks can be added similar to those quoted from the Critique of Pure Reason, not only on the relation of freedom to necessity but also on the possible kinds of necessity. The most important passages for our question are to be found in the "Critical Explanation of the Analytic of Pure Practical Reason." Kant affirms e.g. that the determining reasons for necessity have "psychological and not mechanical causality, i.e. they effect action through representations and not by bodily movements." It would even be possible to speak of a "mechanism of nature" in a quite general sense of a universal necessity of all events, "although this does not mean that things subject to this mechanism would have to be real material machines."

Kant, then, is very far from being a dogmatic "parallelist," or, to speak only of the physical side of the parallelistic doctrine, a phenomenalistic materialist. He leaves much undecided and writes very indefinitely. In the Practical Reason especially the distinction between, and supposed reconciliation of, freedom and necessity is the only thing of importance to him: and similarly the Critique of Judgment has not really a biological-scientific, but a moral end.

${ }^{1}$ See also W. Ernst: "Der Zweckbegriff bei Kant und sein Verhältnis in den Kategorien," Kantstudien, Ergänzungshefte No. 14, 1908. 
Finally, without any further comment I reproduce the following passage from the "Doctrine of Method of the Practical Reason": "The spectacle of a countless multitude of worlds dwarfs into insignificance my importance as an animal creature which must render back to the planet the dust out of which it has come, after having been endowed for a short time (we know not how) with the force of life." 1

That seems to be a clear and unalterable declaration in favour of Vitalism, going even further than the autonomy of mere action, but within the range of the universal determination of natural phenomena.

So I believe that I can justify my chapter on Kant in its original form. That it is not entirely satisfactory is to be attributed to Kant himself. Kant has, as it were, two different notions of causality; firstly, the wide one which is quite compatible with Vitalism, "All that happens pre-supposes something on which it follows according to a law," and secondly, a narrower mechanistic conception in conformity with the ideas of his age. All obscurities arise from his not having kept these clearly separated.

I conclude by adding a passage from the Critique of Judgment: In section 8 he speaks of the "vis locomotiva" of the soul, "because actual motions of the body arise, the causes of which are in its (i.e. the soul's) representations." That hardly sounds "parallelistic."

1 The italics are mine. Compare the words from Dreams of a Spirit Seer: "The principle of life seems to me of immaterial nature." 


\section{(e) THE VITALISM OF THE NATURE- PHILOSOPHERS.}

The philosophy of nature of Schelling and Hegel probably set out ultimately from the idea of a techtonic of peculiarities in nature which would suit our "power of judgment." Nature is the "idea in its otherness" ; natural objects, especially organisms, are as it were solidified manifestations of the idea.

All this is exposition and not explanation: it gives us no doctrine of the laws of becoming. In its most general aspect, then, the theory is irrelevant for biology, especially for Vitalism ; it would accord principally with a static and with a dynamic teleology, both of which regard the organic forms as products of law in opposition to products of chance. But as soon as we try to connect the world of ideas with the world of direct data, nature-philosophy enters into relation with the problem of Vitalism. The relation between pure nature-philosophy and its attendant Vitalism is about the same as between Plato and Aristotle. With Plato the link between idea and reality was wanting, and for us, therefore, he does not come into consideration; Aristotle established the connexion, and he thus becomes 
important biologically, and this in the direction of Vitalism. We shall see that even the biologists, setting out from a philosophy of nature of the Schelling-Hegel school, became important in relation to Vitalism. Schelling and Hegel themselves have not got this importance and do not aspire to it, for as we have said they expound but do not explain. With reference to the doctrine of real organic becoming and its laws Schelling is anything but clear; he rather shows a continual hesitation between vitalistic and teleological-mechanical riews, though with an inclination to the latter. ${ }^{1}$ Hegel, too, when he describes life as a continuous fight. against elementary forces of objectivity, ${ }^{2}$ has indications of a Vitalism, but nothing complete.

Nature-philosophy coincides on purely scientific grounds with the creation of the conception of what is called "type," which forms the basis of a strictly systematic classification of living beings. But we cannot here follow more closely the history of biological systematics in so far as it is occupied only with a realistic analysis of typez, or in other words, in the creation of a system. Further, we may refer the reader to the history of the theories of biology by Em. Rádl, as well as the later essays of Rudolph Burckhardt. The inrestigator of types becomes of importance to us only when treating the problem of the law by which the type is realised for the time being in the individual, or how

1 See his works: C. Weiss, rol. ii. p. $2 \$ 1$ fi., and Metzger's raluable essays "Schelling and the Fundamental Problems of Biology" (Archiv f. Gesch. d. Naturw. 2, 1910), and "The Epochs of Schelling's Philosophy, 1795-1802," Heidelberg, 1911.

${ }^{2}$ Kleine Logik, ed. Bolland, p. 288 ; cf pp. 229, 268, etc. 
it changes its specificity, if such a change, i.e. a descent, is otherwise assumed; and if, supposing it to be assumed, it is treated in a way different from the typically materialistic ${ }^{1}$ or substantially insufficient. ${ }^{2}$

It follows that in our exposition a man like Cuvier cannot be more than barely mentioned : for though he is "vitalistic" in the fundamental physiological questions, he is not independent. This fact is not surprising considering the substantially different sphere of his work: in general he declare.s himself in agreement with the theories of Bichat.

Even Goethe's views on the philosophy of nature, which, as is well known, deal particularly with the concept of "type," but in which the word "entelechy" is also found here and there, cannot be more than mentioned here: they have hardly meant any discernible progress for the history of vitalism. Nor can we do more than refer to

${ }^{1}$ As, for instance, by the Neo-Darwinians.

${ }^{2}$ As such must be reckoned the theory of descent promulgated by Jean Lamarck (Philosophie zoologique, Paris, 1809), though it contains many valuable ideas. It is a purely fictitious construction, and no proof is offered. At the foundation of the formation of types, Lamarck puts a "law of organisation," which he does not define further : use and disuse only make irregular the regular stages founded on this law. The question of the modus operandi of use and disuse (the effects of which he wrongly imagines to be inherited), is left unconsidered by Lamarck: otherwise he would have recognised at any rate its teleological or adaptive character, as Samuel Butler, August Pauly and other "Neo-Lamarckians" have most decidedly done in recent times. What he says about organic life in general is unimportant, and he confuses condition (heat, electricity) with the essence of the matter. For the rest he really admits an autonomy of vital processes, and probably only combats the vitalistic theory out of dread of introducing supernatural factors; but his views here are far from clear. 
A. v. Humboldt's allegory on vital power, "Der rhodische Genius." 1

The vitalistic views which we have first to consider are unfortunately not calculated exactly to meet with the reader's approval.

\section{(i) OKEN.}

Lorenz Oken (1779-1851), the great anatomist, wrote (like many of his contemporaries) a Manual of the Philosophy of Nature. ${ }^{2}$

Galvanism is described as the principle of life. There is no other vital force, we are told, but galvanic polarity. The heterogeneity of the three terrestrial elements in a closed individual body is the vital power, but of course "it is combined with higher actions," and he rejects an elementary vita! force only when it is described as a "force." His thought is anything but clear, and when we hear such sentences as, "The Light shines upon water, and the water is made salt. The Light shines upon salt water and the water lives" - and there are many such sentences in the book-then we are likely to lose our confidence in the nature of his reasoning altogether. Rather than analyse such an idea further, we might have done better to examine minutely the pre-Aristotelian and medieval biologists

To a certain extent Oken's book, Die Zeugung ${ }^{3}$ offers us something better, though at the first glance

${ }^{1}$ In Ansichten der Natur, ed. Bölsche (Reclam), pp. 383 ff. In the explanatory note, however, Humboldt practically withdraws the substance of the allegory. A "vital force" is for him at any rate problematic.

${ }^{2}$ 2nd. Edn., Jena, 1831. $\quad{ }^{3}$ Bamberg and Würzburg, 1805. 
there is also a propensity towards absurdities. In spite of Spallanzani and his successors, Oken rejects the origin of infusoria from germs and attributes it to spontaneous generation ${ }^{1}$ he emphatically proclaims the principle, "Nihil vivum ex ovo," etc.

But then follows an epigenetic-vitalistic theory of generation: The sperm is a putrifying substance, the spermatozoa are protozoa arising from it; at fecundation the sperm (in this sense) unites itself with the "feminine vesicle," and as soon as this has happened the embryo is ready. The spermatozoa have "taken form" in the feminine vesicle.

"Generation ... is the synthesis of the infusoria by means of the homogeneous but opposite pole of the organic world." "The feminine vesicle provides neither a germ nor elementary organic particles nor anything material, but only the form which unites the entering cercariae in such a way with each other (through the organic activity which has come into being with the vesicles), that, though still transparent, they already represent in miniature the type of that animal to whose genus they belong. The vesicle could be simply called the force which gives the type."

So the embryo is formed "straight off, as soon as the spermatozoa are united with the vesicles."

This is a very convenient kind of epigenesis. No doubt the reader will be amused, or perhaps he will blame us for mentioning Oken at all when he reads such wild nonsense as, "The animal is the highest union of polyp and plant, of line and circle

1 Not from inorganic matter in the strict sense, but (as with Needham) from putrifying organic matter. 
-their fusion gives us an ellipse, a fact which everybody can easily demonstrate for himself."

But in spite of all that we reject, one thing should not be forgotten : in substance even Oken's curious theories are based on the fundamental truth of Vitalism, the irreducibility of the organic form.

But the kind of Vitalism which cannot be held up as an example is sufficiently represented by our one instance.

(ii) REIL (1759-1813).

If we wish to give a clear account of what J. Ch. Reil, the type of a clear-headed biologist trained in the philosophy of his age, looked upon as his problem, we may best proceed from the contents of a letter which he wrote (February 22, 1807) to Autenrieth. The contents of this letter are given in a work which we shall shortly have to mention.

He speaks there about the "problem which no natural philosophy has yet solved, how to reach the matter from the idea." We might indeed well ask, why does the idea come to the matter at all, and why must new matter constantly come in through nutrition and old matter be ejected through excretion?

Reil tries to solve in his own way the difficulty which presented itself in his articles "Concerning the Life-force." 1

Everything is matter or representation ; a change of matter is, on Cartesian principles, thinkable only as motion ; representations are always accompanied by simultaneous movements of the brain, though of course not in the sense of a strict parallelism. From this it follows that before the existence of the ${ }^{1}$ Reil's Archiv für die Physiologie, i. 1796, p. 8. 
brain all natural occurrences must have been based upon matter alone; and this argument, conceived in a sufficiently realistic manner, serves to refute Stahl. But in a positive direction it leads us " to seek the cause of all the phenomena of the animal body which are not representations ... in animal matter-in the primary diversity of its elements and in their combination and form."

The power of matter (which with Kant is conceived dynamically) to produce phenomena which depend on its form and mixture, is called the "property" of matter.

The cause of the regular formation of animal bodies lies originally in the nature of animal matter.

It must be understood that matter is here thought of as a whole. Reil does not find the principle of life in a mechanical organisation, although organisation exists even to the smallest details ${ }^{1}$ on the contrary, "the most general attribute of this unique animal matter is a special sort of crystallisation."

"We can describe as force the relation of this property of the animal matter to its effects," namely, "the adding of foreign substances from outside and their purposive formation. This has been given the name formative-force and formative impulse." Reil denounces only the names, but not the whole conception. He strongly emphasises the fact that his "force" has the character of natural law and that it is combined with the "dead forces" in the organism.

${ }^{1}$ Reil expressly rejects the view that the order in generation, alimentation and growth comes " through instruments." 
We have no interest in going into further details of Reil's exposition: he does not offer real proof of the objective truth ot his kind of Vitalism. We will on!y mention the excellent definition of irritability, as it is an example of his logical clearness : "The quality of animal organs which causes them to change their present state through themselves when stimulated by an external agency, is called irritability." The cause of irritability lies in the mixture and form of the matter.

Reil is the first representative of a vitalistic theory founded on the concept of living matter and thought out clearly, perhaps too simply for the greatness of the problem of how one "comes from idea to matter"; he merely endows the matter with the idea. In a sense this too sounds quite modern; but we must not forget the sentence which we have already quoted from Kant, "The possibility of a living matter is unthinkable; the concept contains a contradiction, for lifelessness, inertia, is the essential characteristic of matter." To those who agree with this thesis Reil's work can be no more than a clever achievement erroneous from the very start.

\section{(iii) TREVIRANUS.}

With G. R. Treviranus, if not already with Reil, we have the beginning of a really dogmatic Vitalism, i.e. Vitalism whose proof is no longer thought necessary, the question being rather how it is to be presented. At the same time with Treviranus begins what might be called "scholastic Vitalism"; every general treatment of physiological theory now 
commences, as it were, with a vitalistic system, for the most part not very different from its predecessors. This continues till Johannes Müller, the last in this group of Vitalists. In every case we notice the secondary position taken by morphogenesis on which interest was concentrated throughout the eighteenth century; instead of it we getstress laid on the chemicophysiological side, and especially the problem of instinct; often also that of "psychic life" ais a natural phenomenon.

If, nevertheless, we treat Treviranus alone, it is because he displays throughout his whole life an anxiety for clearness in vitalistic matters, and because there really are quite original ideas in his work.

In the years 1802-1822, there appeared six volumes of his Biologie, oder Philosophie der lebenden Natur, and the first in particular is devoted to general questions. In the long process of preparing his book Treviranus changed his outlook on many essential points; so towards the end of his life he gathered together his final views in a new work, to which we shall refer later on.

It is worth noticing that with Treviranus the word biology is used for the first time to designate the whole of the theory of the living : "The subject of our researches will be the different forms and phenomena of life, the conditions and laws under which this state occurs, and the causes which produce it. We shall designate the science which is occupied with these things as biology or the theory of life."

Treviranus reproaches his predecessors for not 
having given a clear-cut definition of what they were investigating; if a definition was given it was wrong, e.g. Stahl equates " liring "' and "animate." 1

- The uniformity of phenomena in relation to external influences" is, according to Treviranus, the fundamental criterion of life, and connected with this definition are all those discussions which characterise his work in particular.

He shares Kant's theory of matter. In the inorganic, where the question is of matter alone, one alteration alters all, because of the principle of reaction. His definition of life would mean the contrary of this. How is this contrary possible? ? Evidently through something extraneous to matter.

We have shown that all matter is organised and subject to constant change, but that in the organisation and in the change there is something permanent only so long as the external influences which cause the latter remain unchanged. The matter of living organisms cannot form an exception; it must, for instance, be impenetrable. The exception, sars Treviranus, which the substance of living bodies seems to constitute to the abore can therefore be only apparent. There must be a dam which breaks the wares of the universe, in order to sare living nature from the universal whirlpool. This mediating force is certainly not the primary force which is needed for the possibility of matter. "We call it

1 Simply by the consideration of the ritality of separate parts of the organism on which representation has no effect.

' In reading Treviranus, it must be remernbered that for him the word " organic" designates "order "" of every lind, and consequently nature in general is an organic system. 
therefore vital force (vis vitalis) to differentiate it from that primary force."

Thus in any case mere form and combination of matter does not contain the cause of life, at least, not if we only admit the Kantian primary forces, repulsion and attraction. But if more primary forces were admitted the question would remain, what holds them together?

So "life is something entirely extraneous to matter" ; and as something new we also find "spiritual nature," Aristotle's voûs.

It must be especially noted that, taken in themselves, the mechanical and chemical changes in organisms are the same as in lifeless nature; but they differ in that the external causes, to which they owe their origin, influence the matter of living bodies not directly but through the vital force.

There are three possibilities here :

Is there vital force only where there is matter capable of life, such that the latter, beginning as a product of the inorganic, when finally formed "wakes" the vital force "from its slumber" ?

Or is matter capable of life a product of vital force?

Or, thirdly, are they "determined reciprocally the one by the other" ?

Treviranus decides for the third alternative in a lengthy discussion where, amongst other things, the vital force is considered quantitatively, and where the conception of a "vita minima" is introduced.

So he uses two fundamental principles, the vital force and matter capable of life. In this he differs substantially from Reil. As might be expected, however, he is somewhat obscure. 
His matter capable of life is in itself formless ; it receives a determined form "through combination with elements of lifeless nature." In death, which thus becomes analogous to the transmigration of souls, all passes through that formless matter. But in particular the relation between vital force, formless life-substance and external factors is imagined by Treviranus in conformity with his definition of the living as opposed to the material, in the following way :

"The nature of life consists in the faculty or power to give relative uniformity to the absolute irregularity of external agents. Different forms of life are possible only if every kind of living organism possesses that faculty solely for certain external agents; in other words, if its vital force acts only when influenced by certain powers, and if all the other powers affect the matter of the living organism, without having first been modified by the vital force."

This statement serves as an explanation of different specific vital forms as well.

What depends on fortuitous external factors, what on the vital force, and what part is to be taken by the formless matter capable of life-all this can hardly be made out from the discussion, though its clear logic is deserving of special recognition.

From the later volumes of the Biology which are more specialised we reproduce very little here.

In the second volume Treviranus once more decides upon his third alternative: first of all, because of the fact of spontaneous generation from organic substance in a state of decomposition, a 
"view which when demonstrated implies the demonstration of the whole of biology," and secondly, because of the fact that organisms are liable to be influenced by external factors like nutriment, humidity, etc. These arguments can hardly be considered happy.

In the fourth volume there is a good sentence: "The organ is a restriction, not the cause, of the activity of the formative impulse."

In the sixth volume the relation between reason and the creative principle is elucidated by reference to somnambulism, hysteria, etc. Here Treviranus comes to the very modern conclusion (reminding us, for instance, of E. v. Hartmann), that something unconscious is the primary cause of life, affecting the body on the one hand and the spirit on the other. In language not quite clear from the critical point of view the instincts are called "unconscious images."

Towards the end of his life Treviranus, as has been noted above, restated his views on the primary principles of biology, ${ }^{1}$ and did it in a substantially altered form.

"Purposiveness for itself," as contrasted with the artificial product, is what characterises life for him ; and it is significant how the instinctive, the unconscious, becomes to him the foundation of all vitalistic theory; in the last volume of the Biology there were already hints of such a view. Consciousness is not a mark of life ; in the instinct the aim is unconscious, in the muscular movement, on the

${ }^{1}$ Die Erscheinungen und Gesetze des organischen Lebens, Bremen, i. 1831 ; ii. 1832-3. 
other hand, "we are conscious of the final aim, not of the means." Purposiveness is conceivable always only as "an analogon to reason": in this sense the sentence which Treviranus rejected in the Biology with reference to Stahl is of value to him now, "Living beings and animated beings (Beseeltsein) are the same."

He considers whether living bodies act and react upon each other without the intervention of the senses; the regulative principle of the number of births and deaths and of sex, and somnambulism, support this view.

But by far the best illustration of the real essence of biological phenomena is instinct. Instinct, in bees for example, rests upon "productive imagination "; it is comparable to dreaming ; it originates in an "obscure consciousness." And embryology may be conceived on the analogy of instinct; it is "as if the germ of the wheat dreamt of root, shoot and ear." Johannes Müller, Schopenhauer and Hartmann advocated a similar conception of morphogenesis in later times.

And finally : "All living things have organisation, but organisation is the consequence of life. Life is a state that is alien to matter as such. As soon as life ceases, the elements of the body, which was animate before, become united by different laws than those prevailing in the former state." Biochemical analyses have therefore but little value. We may here recall Bichat's " anatomie cadavérique des fluides."

As for spontaneous generation, it now seems to Treviranus "at least unproved." 
(iv) THE DOGMATIC SCHOOL.

M. F. Autenrieth produced a very readable book about the principal problem of biology, Ansichten iiber Natur- und Seelenleben (1836). But there is little question of close analysis, and the way for the later criticism of a Lotze is being made easy ! There is in life, he holds, something essentially different from material substance; this "vital force" is independent of the body. This is proved through the spontaneous generation of infusoria and of intestinal worms, and not less through the fact that single organs or whole organisms, e.g. fishes, can freeze and thaw again later on : here the vital force, which is a really measurable force, had altogether or partly left the body.

The catastrophic theory, too, proves the independence of the vital force, and just as great a proof are the facts of fertilisation; the physical element is unessential, as very few germs suffice.

The best part of Autenrieth, though it is similar to what we find in Treviranus, is what he says about instinct, which " is based on the creative principle of the vegetative vital force." Instinct is not reason, but it can be combined with it as in the case of bees, cats, or dogs.-

$F$. Tiedemann ${ }^{1}$ thinks the "effort of metaphysics to give a complete knowledge of nature by idea of the reason (Vernunftideen) a failure and yet a desideratum."

His own bio-theoretical inquiries introduce chemical considerations which begin now to play a part, at ${ }^{1}$ Physiologie des Menschen, i. Darmstadt, 1830. 
any rate incidentally. There are only binary combinations in the inorganic; therefore in the organic, where they are ternary and quaternary, there must be forces acting "against the affinities." It is true that urea and oxalic acid have been produced synthetically by inorganic means, but these substances "stand on the extreme limit between organic and inorganic compounds"-a mode of expression which is equivalent to a confession of uncertainty as to the previous statement.

Organisms are by form more multifold than the inorganic, but by "mixture" more uniform ; whence can be deduced a force peculiar to the former, a "higher power which acts in formation." This power "modifies" the affinities, though it has its limitations.

Further considerations concerning spontaneous generation of infusoria and worms from decomposed elements (or rather the capacity of revivification when the substance is not quite dead) lead Tiedemann -not very logically - to postulate the existence of a "vital matter" such as Reil had already affirmed, though by a more rigorous method. The material substratum of organic bodies is a unique substance, and possesses the property of forming itself; it was in fact contained in water and formed itself. Thus everything is settled at once. But Tiedemann has to admit that "the main difficulty is not explained."

Further on our author refers to the "peculiar matter capable of life" of Treviranus, but does not penetrate into his predecessor's not altogether clear 
but much deeper conception; he also cites Buffon and Needham with approval.

Blumenbach's "nisus formativus" is described as obscure ; we may, however, ask ourselves whether Tiedemann's conclusions, which never reach real logical accuracy, are not themselves obscure in a much higher degree.

$\mathrm{He}$ is at his best on certain details such as the idea that the existence of inanimate bodies depends " on the state of rest which occurs in chemical composition," while the existence and conservation of organisms is conditioned by continual changes of composition. This reminds us of the modern conception of "dynamic equilibrium." The difference between crystals and real "individuals," or organisms, is also well discussed.

There is nowhere even so much as an attempt at a real proof of vitalism, except the unfortunate introduction about the relation between biology and chemistry.-

Still more than the above-mentioned writers is $K$. F. Burdach ${ }^{1}$ under the spell of natural philosophy. The life-principle is not a "deus ex machina," but a "deus ex vita"; no mechanical, no chemical theory is sufficient to explain organic formation. But the life-principle is not to be imagined as isolated from matter; it works "through material means," through common activities of the organism such as secretion, assimilation, etc. "Matter is only an accident, while activity is the substance of the organism."

${ }^{1}$ Die Physiologie als Erfahrungswissenschaft, Leipzig, 6 vols. Of special importance are v. 1835 , and vi. 1840 . 
In the course of development, he declares, the progress of further formation is always stimulated by that which already has been formed. This really lucid epigenetic idea deserves particular recognition.

So far the fifth volume; in the last Burdach tries to probe still deeper.

All forces of the inorganic world are certainly active also in the organism; this was an axiom on which Descartes and the Iatromechanists had built. They explained the mechanics of the articulation of limbs and some points in the circulation of the blood, and then thought that they could explain everything. In doing so they neglected the high philosophical standpoint of Descartes.

But the materialists have not proved anything; any more than men like Buffon and Needham.

Materialism can explain only details, but never their relation to the whole. But a general organic matter endowed with special power is no explanation, quite apart from the fact that such a thing cannot really exist, since life is developing towards individualism. Electricity and heat cannot be the cause of life, as they presuppose the variety of living organic forms: explanations resting on irritability and the like are simply classifications. Stahl's soul, too, is to be rejected no less than a nerve-principle put in its place: there is life without nerves. Finally, the term "vital force" implies only "that there must be a peculiar cause for the peculiar phenomena of life."

But what is to be done where all these theories fail ? 
Life must be explained "by the cause of existence alone." A reference follows to Fichte and Schelling : "We find in the organism the same predicates in a limited form which apply in an absolute sense to nature in general."

"Vital force is the primordial thought realising itself within certain limits."

Is such a solution satisfactory? Hardly, for a true scientist. Reil's question, how do we come from the idea to matter? must be raised and not merely shelved.

Essentially, Burdach offers us no more than Oken, except that he is kept from obvious absurdities by logical training and critical capacity, which in general make the study of his work agreeable reading, and such as one can recommend.

Schopenhauer often quotes Burdach favourably; and what he valued was, of course, the metaphysical element, the "Will in Nature." We must also remember that Schopenhauer was not quite so far from nature-philosophy as he himself believed.-

Karl Ernst v. Baer, the celebrated embryologist, was a pupil of Burdach's, and depends on him in his early theorising, which alone interests us here. He is also greatly influenced by nature-philosophy, and it will become clear later on that in matters teleological he never got beyond such dependence. We need not have referred to his book, ${ }^{1}$ which, though epoch-making for embryology has very little importance for Vitalism, were it not for a sentence which appears in the dedication to Pander; that sentence

1 Über Entwickelungsgeschichte der Thiere, Königsherg, i. 1828, ii. 1837 . 
unfortunately has often been quoted by materialistDarwinian authors in order to label Baer as one of themselves :-

"Many a man may get a prize; but only he will win the palm for whom it is reserved to trace the creative powers of the animal body back to the general powers (or vital tendencies) of the universe. The tree which will supply the wood for his cradle has not yet been planted."

Such expressions show what is indeed also sufficiently indicated by the words "vital tendencies," that Baer could not well be further from a materialistic conception of nature, and that he thinks more in the spirit of nature-philosophy. ${ }^{1}$

"There is one fundamental idea which runs through all forms and stages of animal development, and commands all relations. It is the same idea which collected the scattered elements of matter into spheres and combined them into solar systems, the same idea which made the decomposed dust on the surface of the metallic planet grow up into living forms. But this idea is nothing else than life itself, and the words and syllables which express it are the different forms of all life."

These might be the words of Oken ; it is certainly far from being the expression of a clear attitude towards the teleological problem, and of interest only because of the light it throws on the author's personality.

The real embryological merit of the book consists, as is known, in the differentiation of the conceptions

1 Baer also emphasises the fact, for example, that explanations by oxydation or electricity deal only with one side of the question. 
"type" (=Lageverhältnis) and " degree of organisation " ; also in the view that the type is conditioned by the development in its embryological manifestations.

But we must bring our remarks to a conclusion, for we cannot deal in detail with every author in an age when everyone thought vitalistically, and when, therefore, every writer who happened to theorise was responsible for a certain number of vitalistic remarks. We will only mention, therefore, that R. Wagner, the editor of the well-known Dictionary, did not agree with the contents of the anti-vitalistic contributions of his collaborator Lotze, with whom we shall deal shortly: also that F. Magendie, though he was interested in matters of fact more than in the theory, differentiated between " purely physical and purely vital events," but at the same time was perfectly clear in his assertion of their intermixture. ${ }^{1}$

And now we turn to consider that man who represents to a certain degree the final type of the old Vitalism.

(v) JOHANNES MÜLLER.

In his Manual of Human Physiology, ${ }^{2}$ Johannes Müller systematically summed up the dogmatic Vitalism for the last time. Müller's book surpasses its predecessors in essentials, and had therefore a wider influence; and moreover, the old Vitalism

${ }^{1}$ Précis élémentaire de Physiologie, 1816. Amongst other things we read of "the harmful and perverse belief that physical laws have no influence on the living body."

${ }^{2}$ Koblenz, lst edition, vol. i. 1833, vol. ii. 1840. Fourth edition, 1844. 
reached later generations chiefly in the form which he gave it. Indeed, he is often regarded as its typical exponent. This is true in a sense; but for the real consolidation of the great vitalistic theory, Müller represents a true progress only in two separate (though not unimportant) points; this, however, is sufficient for us to give him a distinguished place, and to treat him as more than merely the last of the school. But an essentially new idea of really fundamental kind is not to be found in his writings.

The book begins with that statement about the chemical contrast of organisms and the inorganic which we know already from Tiedemann, and which, as Müller emphasises, took a definite place in every contemporary book on chemistry; even the problem of urea has almost literally the same solution as with Tiedemann. Besides selective affinity there is "something else" which rules in life.

The Kantian view of the organic is next introduced, and the treatment of the conception of individuality reminds us once more of other predecessors. Somewhat more original, at least in its form, is the idea that the harmony which exists in the organism between structure and function is sufficient for the characterisation but not for the explanation of the organising powers, as the latter had existed before.

Then Müller brings some arguments against the embryological evolution theory ; epigenesis, on which he touches only slightly, is improved in so far as spontaneous generation of all kinds is definitely 
rejected, with reference to Spallanzani; and in so far as the permanence of organic matter is affirmed.

Müller finds the views of Stahl particularly congenial, but we seriously doubt whether Stahl referred not to the representing Soul, but to the "organising force expressing itself by a rational law." This formula, however, sums up Muller's own theory. It is certainly not new, and when he declares consciousness to be a creation of the organisation, and further, to be attached to an organ, the nervesystem, we cannot but remark the confused character of his expression from a critical standpoint.

Whence arises the connection of that force with organic matter is not for Müller a matter accessible to human knowledge. This view implies a real progress in comparison with earlier writers.

But this praise needs an immediate limitation when with reference to Reil the question whether or not that new element in life is material is described as uncertain. Müller is here equally far from the clear analysis of his problem, which led Reil to his life-substance, and from the logical argument of Treviranus, who was able to reject Reil's solution.

The most important passages of Müller's first volume are those which arise from the discussion on the so-called life stimuli, or integrating stimuli (i.e. in our language the necessary conditions of life), and from the treatment of the problem of death. These stimuli vivify the organic forces and strengthen them. Through the vegetable world the vital force is increased from unknown external sources. There must be such an increase, since the organic force is multiplied in growth and in 
the reproduction of organic bodies: and hence we must admit "the inconceirable theory that the division of the organic force which takes place in reproduction causes no diminution of the force itself." In death, on the other hand, the organic force is resolved into its general natural causes, whence it seems to be regenerated once more through the regetable world.

All these considerations do not seem at first sight. at all clear, nor are they all new ; indeed, we already had occasion when dealing with Müller's predecessors to object to their habit of understanding the vital force in a quantitative sense. But what is a really original consideration is the way in which Müller, though presupposing the wrong idea that the vital force itself can be understood quantitatirely, raises the question of the origin of that quantity; or, in modern terms, the way in which he requires a sort of "source of energy" for it. Truth and error are mingled here; rather we should say, of course, there must be a source of energy for phenomena of life, but that which really characterises them has nothing to do with a source of energy.

After the manner of the Aristotelians, Müller distinguished a regetative power. a motive power, and a sensitive power; everything originates from the "primum movens," whose creations become more and more specific. The reason ascribed to that "primum morens " is far mightier than human reason: "all problems of physics are determined by this creative activity." It is also the cause of the instincts which, as by Treviranus, are regarded as a form of dream. 
Besides the anxious demand for a "source of energy" in life, Müller, in the second volume of his book, treats the so-called problems of psychic life as really scientific problems of physiology; though he does it very confusedly, and uses the words "freedom," "sensation," etc., in a very vague way.

The question whether soul and matter are necessarily connected is left open, like the question of the connection of matter and vital force. "The will sets in activity the nervous fibres like the keys of a piano." All the rest is nothing but mechanism. The existence of the soul does not depend on the uninjured brain, inasmuch as it was already latent ${ }^{1}$; and thus the soul cannot be sick, but only the brain. But how that action on the nerves takes place is perhaps an unanswerable question. In any case it cannot be attributed to the intensity of an idea of purpose, for in that case the movement would have to increase with any increase in the intensity. Nor can it be attributed to the fact that the soul is filled with one single idea, for several movements can be executed at once. All this cannot be regarded as over critical, but a point which is worth mention is the emphasis on the relation of will to attention which recalls the writings of Wundt: while the views of Lotze are foreshadowed in the theory of the origin of volitional movements from the indefinite movements of new-born babies through the medium of experience. Particularly noteworthy is also Müller's doctrine of the unimportance of the brain

1 We may quote the passage: "With the structure the acting of the force already at hand (from the germ) is given; the force, then, does not ultimately depend on the structure of the brain, though the possibility of its working depends on this structure." 
in spite of his theory of specific sense-energies. Loss of brain substance never results in the loss of definite ideational complexes, but in the diminution of the clearness of all ideational activity.

Some very general remarks conclude the theoretical part of Müller's work, and with them we may also close our examination-" The relation of soul and organism can in general be compared with the relation of every physical force of a general nature to the matter in which it is manifested: as, for instance, light and the body in which it appears. The enigma is the same in both cases."

The effect of spirit on body or of body on spirit is conceived by Müller according to the scheme of the monadology of Herbart.

\section{(vi) LIEBIG.}

We may conclude this part of our exposition by briefly examining the views of a famous chemist on the phenomena of life. The passages where Liebig refers in his Letters on Chemistry, ${ }^{1}$ and less profoundly in his Animal Chemistry, ${ }^{2}$ to the fundamental problems of biology are not concerned specially with the details or the establishment of Vitalism, but they are notable because they have a certain general character, and because they also show that the chemists of this age, of whom Liebig may be taken as the representative, were very far from being opposed to Vitalism.

Although chemical force and rital force are nearly

${ }^{1}$ Leipzig, 1844 ; 4 th edition, 1859.

2Die Tier-Chemie in ihrer Anvendung auf Physiologie und Pathologie, Braunschweig, 3rd edition, 1846. 
related, and the chemist can already produce all kinds of organic substances and will one day be able to produce a great many more, chemistry will yet never be in a position to create an eye, a hair, or a leaf. The form, the qualities of the simplest groups of atoms are determined by the chemical force under the dominion of heat: while the form and the qualities of the higher and organised atoms are conditioned by the vital force. The latter, of course, has its limitations, and cannot for instance transcreate the elements.

The anti-vitalistic materialists have mostly proceeded in far too summary a fashion, and of course the same applies to the methods of the vitalists, since they failed to realise certain possibilities. But none the less the vitalistic view is the right one.

"Only an insufficient acquaintance with the forces of inorganic nature can account for the frequent denial of the existence of a special force in organic beings, and for the ascription to inorganic forces of modes of action which are opposed to their nature and which contradict their laws. Those who venture on such a denial are ignorant that every chemical combination presupposes not one but three causes," viz. besides heat and affinity "the formation force of cohesion and crystallisation." "In living bodies there is added yet a fourth cause which dominates the force of cohesion and combines the elements in new forms so that they gain now qualities-forms and qualities which do not appear except in the organism."

Opponents of Vitalism are, according to Liebig, mostly strangers to the sciences which investigate 
physical and chemical forces. His view reminds us of the fact that in modern times physicists and chemists have often been far less prejudiced in their views than biologists. We have only to think of Ostwald, Hertz, Maxwell and others. One could easily imagine that Liebig was writing in the sixties or eighties of the past century, instead of many decades earlier, when one reads his remarks about " dilettanti who have strolled as far as the portals of scientific research, and then claim the right to discourse to an ignorant and credulous public how the world and life really arose and how far we have got in the solution of the deepest problems," of whose disquisitions on the relation of body and mind nothing remains when they are divested of all their gaudy trappings, but the single assertion that we can no more think without a brain than walk without legs.

Only if we regard it as an aberration of naturephilosophy can we, according to Liebig, in some degree find an excuse for materialism. But none the less vital qualities are not to be regarded as an exception to the laws of nature.

Our study has now brought us to a time when Vitalism has at any rate to fight for its existence, when there are other candidates in the field. But before we enter in more detail on the new situation we will give a second ending to this part of the discussion. We began it with a reference to the nature-philosophy of Schelling and Hegel, and we will conclude it with another reference to philosophy-to one who, if he were still alive, would perhaps take it very much amiss to be mentioned in the same paragraph as his enemies the "Professors of Philosophy," but 
who certainly neglected similarities in stressing differences-to

(vii) SCHOPENHAUER.

We are not here concerned with Schopenhauer's metaphysic of volition any more than with the rational systems of his opponents. When, in the course of his work, he has to demonstrate the fact that nature shows various stages of the "objectification of the will," of which the highest is the living organism, he adduces a great number of biological facts ${ }^{1}$ regarded from a general vitalistic standpoint : and these present a valuable field for scientific analysis. ${ }^{2}$

Of immediate scientific interest and methodological importance is one definite thought which we find in Schopenhauer. It is attached to his criticism of the Kantian philosophy, and to the part dealing with the teleological judgment in particular, and runs as follows :

"Kant rightly asserts that we can never succeed in explaining the nature of organised bodies from merely mechanical causes, by which he understands the undesigned and regular effect of all the universal forces of nature. Yet I find here a gap. He denies the possibility of such an explanation merely with regard to the teleology and apparent adaptation of organised bodies. But we find that even where

${ }^{1} \mathrm{Cf}$., in addition to the second book in both volumes of his chief work, his publication On Will in Nature.

${ }^{2}$ Most important is the parallel between instinct and the operation of organising nature in The World as Will and Idea, vol. ii. book 2, chapter xxvii. (English Trans. by Haldane and Kemp.) 
there is no organisation the grounds of explanation which apply to one province of nature cannot be transferred to another, but forsake us as soon as we enter a new province: and new fundamental laws appear instead of them, the explanation of which is by no means to be expected from the laws of the former province. Thus in the province of the mechanical, properly so called, the laws of gravitation, cohesion, rigidity, fluidity, and elasticity prevail, which in themselves (apart from my explanation of all natural forces as lower grades of the objectification of will) exist as manifestations of forces which cannot be further explained, but themselves constitute the principles of all further explanation, which merely consists in reduction to them. If we leare this province and come to the phenomena of chemistry, of electricity, magnetism, crystallisation, the former principles are absolutely of no use; indeed the former laws are no longer valid, the former forces are overcome by others, and the phenomena take place in direct contradiction to them, according to new laws, which, just like the former ones, are original and inexplicable, i.c. cannot be reduced to more general ones. . . . Such an exposition would have been especially favourable to his excellent remark that a more profound knowledge of the real being, of which the things of nature are the manifestation, would recognise both in the mechanical (according to law) and the apparently intentional effects of nature one and the same ultimate principle, which might serve as the more general ground of explanation of them both."

These reflections do not quite harmonise with 
Kant's ideal of a resolution of all physics into phenomena of movement, but they are none the less right. They are, moreover, of the greatest importance both for the general method of science and for biology in particular. They are extended in Schopenhauer's further doctrine that all the elementary laws of nature are the more intelligible the poorer they are in content, and the less intelligible the richer in content. But biology he regards in a vitalistic sense as an independent science with special irreducible laws, though life for him is at the same time only the last member of a series and in no way contrasted with the rest of nature. ${ }^{1}$

Schopenhauer's whole conception has a peculiarly modern ring with respect to questions of method, and directly anticipates the ideas of Mach and Paul du Bois-Reymond.

\section{(viii) THE END OF THE OLD VITALISM.}

It is said of political parties that they die out when they no longer have opponents to contend with.

1 The idea that the different branches of natural scienceMechanics, Physics, Chemistry, Biology-have to deal with phenomena which ever grow more complicated, is also found in Comte's Cours de Philosophie positive, vol. iii. 3rd edition, Paris, 1869. His dread of metaphysics and "entities," his "Positivism," prevented his understanding the real problem of Vitalism. For his Positivism was in reality an imperfection, since it overlooked the $\dot{a}$ priori necessity accompanying the formation of concepts and judgments, and he also leaves it uncertain whether he believed that in each branch of natural phenomena there is an autonomy of a growing intensive complexity, or merely a complication of the configuration. The first alternative seems to us the more likely. These few words, however, must suffice on Comte, as in Claude Bernard we shall later have to deal with a thinker who adopts the same point of view, with a better scientific foundation and training. 
Something similar is also true of scientific and philo sophic theories; it is not as though they cease to exist as such, but they lose their strength, their capacity for being always ready to face an attack which is always possible and perhaps not altogether unjustified; they become lax and careless in their logical deductions; they forget to justify erery assertion in the light of the theory of knowledge. But what is worse still, they become careless with regard to their fundamental principles : they regard these as so certain that it is no longer worth while to examine them, no longer worth while even to mention them: still less do they endeavour to establish them yet more strongly by the new facts that might be adduced from actual experiments.

In such circumstances a doctrine declines and eventually dies. It may, of course, have nevertheless been the right explanation, but what was right in it was buried under a mass of confused and false details. The opposing doctrine which takes its place cannot be said to have refuted its predecessor as a whole; for it has refuted only certain particulars which were wrong and not well founded on it. It proceeds, howerer, with an acute and rigorous logic; it fights earnestly for its own existence; it attracts to itself all the unoriginal thought of the time, and overlooks the fact that it has never really touched the kernel of truth which lay in the older theory, which has passed away through its own carelessness.

But, finally, the old theory rises again in a new and improved form, thankful for honest and well founded 
criticism, even though that criticism was wrong in its essentials - and that is exactly what happened in the case of the old Vitalism.

It died for lack of opponents. Who of all those writers whose doctrines we have examined had during the last six decades really examined the fundamental principles of his theory, who had endeavoured to put forward an objective justification of his own doctrine as opposed to others, who had proved his conclusions? Blumenbach was the last of all these naturalists who really undertook this task.

Thus it was that a critique came to the front which, to all outward appearance, had set Vitalism on one side for the time being. But Vitalism had not been overthrown; it had only been purified, and hence it is that we lay stress on our statement that the old Vitalism died literally by a process of self-extermination. 


\section{CHAPTER II.}

\section{THE CRITICS : AND THE MATERIALISTIC REACTION.}

OF all the criticisms and negations which in the middle of the nineteenth century and even somewhat later were directed against the older Vitalism, there are only two which are good, only two which do not content themselves with mere verbalism. These two, however, are first rate, and they emanate respectively from Lotze and from Claude Bernard. But it is curious to observe how, in spite of all criticism and negation, both thinkers were forced by the sheer weight of facts to admit the truth of much in the vitalistic theories.

Their objections are indeed in the last resort criticisms, and not actually refutations ; and what claimed to be a complete refutation bore, as we have already asserted, and shall now proceed to prove, the most manifest superficiality.

The fact that in spite of their real import both these critiques were, owing to the materialistic and sensational tendency of the time, interpreted entirely amiss and in a manner contrary to the intentions of their originators as absolute 
refutations, in no wise impairs the correctness of our view.

\section{(a) LOTZE.}

H. Lotze's article, "Life and Life-force," in the first volume of Wagner's Dictionary of Physiology (Braunschweig, 1842) is the most solid of all attacks upon Vitalism. And yet there were many misunderstandings. Thus when Lotze asserts that a "Life-force" is out of court from the beginning, because no natural event has only one cause, we can reply that he could have dispensed with this apparent attack if he devoted himself to Wolff or Blumenbach rather than to his contemporaries. The "Accessory Principles" of the former writer would certainly have shown that the objection was beside the mark.

This is noticeable over and over again. Exaggerated expositions of Vitalism had become so numerous that the writers of the day easily lost sight of what was still the correct view.

Against the "matter capable of life" of Treviranus, the critic objects that it is really superfluous since specific forms must result from the relations of Life-force and outside factors. The objection is valid : but it does not touch Vitalism as a whole.

And when Lotze turns to the migration of the independent Life-force in Autenrieth's sense, and observes that the doctrine of the ancients, that life-forms are ideas, was really better, we who profess Vitalism are entirely on his side.

Schelling and his successors, according to Lotze, " never had a clear conception of the relation of a legislative idea to its executive means." Their idea 
of the species as a legislative power is as it were an equation for the curve of life. But with them the equation not only determined but described the path of the curve.

To this also we gladly subscribe : but it does not seem to us so very new. We remember, for instance, that the problem "how to come from idea to matter" weighed heavily on Reil.

What Lotze really means in general is this : the formative impulse can never "explain" anything, as here the "law" is lacking. At the most, it classifies.

What then is meant by "explain" and by the "law" ? Lotze is probably thinking of quantitative laws; but where are they to come from when the substance is not quantitative? And what else is meant by the "explanation of events" than their subsumption, under appropriate schemata? This, indeed, is our opinion, and Lotze is here preoccupied with the intentions of mechanistic physics.

When Lotze goes on to say that the regulative element in the processes of life is no proof of Vitalism, since it is not always present, he is guilty of a confusion too often made even to-day. A series of facts can only serve as proof where it occurs, and never where it does not occur. I cannot study optics in a dark cave, without the aid of a light. Only when a series of facts actually occurs can the question of its validity as a proof arise.

But when Lotze sets the occurrence of " monstra" in the scale against Vitalism, and speaks of the "horrible" creations achieved by the liberation of mechanism, we can only reply that Blumenbach 
was quite aware of the actual facts and yet remained a Vitalist.

The long disquisitions directed against the designation "life-force" and against "division" of this "force," are however quite to the point; but it should be held in mind that the dispute is only about a word which was actually avoided by many Vitalists, and also that the great service of Lotze's contemporary, Johannes Müller, consisted in this, that he sought to make plausible to himself the concept of something like a source of energy for vital phenomena.

It produces a curious effect, after all that has been said, when we suddenly learn from Lotze that old Stahl's doctrine of the "soul " controlling all events of life was not such a great mistake after all; for here the soul is conceived of as a "substance," and thus something at least which can produce an effect is introduced.

It almost seems as though in the whole of Vitalism Lotze had taken offence at the use of the word "force" alone. But this would be erroneous. $\mathrm{He}$ rejects Vitalism as a theory of the actual facts of vegetative and formative processes, and at the end of his observations on the matter he expressly declares that organisms are "machines," a concept which must be taken in a very broad sense. ${ }^{1}$

Up to this point, then, Lotze is a static teleologist. A man of his stamp could obviously not sink to the

${ }^{1}$ Later on the formative impulse (conceived in a primitive epigenetic manner) as well as the facts of physiology proper are described as mechanical. 
absurdity of denying the irreducible uniqueness of purposiveness.

But now comes the second part of the article, which treats of the "Life of the Soul" 1; and now the philosophic physiologist becomes a confessed Vitalist. It was for this reason, no doubt, that also in the sphere of vegetative Vitalism Stahl's view was to him the most sympathetic.

The "soul " as something entirely new in relation to the rest of nature is able to provide an absolutely new beginning for mechanical movement. Lotze insists that this fact must also be accepted if there really were such a thing as a healing power in organic nature.

We see here clearly how on the one hand his false dogmatic mechanism, and on the other his conception of the soul as something that is alien to nature, removed Lotze from a really unprejudiced interpretation of the subject.

Now how does the soul operate according to its own laws?

Thoughts, ideas as such, "have not the slightest power to move masses, or indeed to move anything. They can, however, attain to such power in so far as they are definite states, modifications, or movements of a reality, of a substance, viz. of the 'soul.' That is to say, states of different substances belonging to the same category are opposed to one another. Cause and effect, however, apply to all that is ' real,' regardless of whether it is body or spirit." Thus every difficulty is surmounted. The "concept of

${ }^{1}$ Cf. also the essays on "Instinct" and "The Soul and Soullife" by Lotze in vols. ii. and iii. of Wagner's Dictionary. 
substance" which is common to spirit and to body renders everything comprehensible.

Lotze even holds the immediate action of the soul upon a foreign body to be possible. On the other hand, he keeps before him the idea of really strict laws of psycho-physical influence.

Thus, in spite of rejecting the actual, biological Vitalism, Lotze came so extraordinarily near to it in his soul-theory that his rejection of it is a cause of perpetual astonishment. A closer analysis of what he actually conceives the soul to be capable of, makes the matter still clearer.

Images, feelings, desires, he says, are only modes of appearance assumed by inner states of the soulsubstance for our own observations. As such they have not the smallest power to move reality. On the other hand, those inner, unconscious states of the soul as substance, which are totally removed from experience and never come within our view, can, in conjunction with the states of that other reality, the body, affect a given mass and initiate an absolutely new movement.

Lotze, in fact, is a metaphysician, as is shown by his conception of a real substance. Furthermore, he admits an unconscious and yet purposive element as an active factor in nature conceived as real : and he even interprets the instincts in an expressly non-mechanical manner. ${ }^{1}$

Why then does he reject Vitalism? Is his view really anything but Vitalism in a special sphere, i.e. in the case of active man, who after all is also a living being? Is there the slightest distinction ${ }^{1}$ Cf. the article on "Instinct " already referred to. 
between his theory of the operation of the soul and that of Johannes Müller? At any rate, he claims that the causal relation of body and soul is no harder to understand than any sort of causality, and he has a thoroughly clear conception of matter.

In truth, it was only contemporary exaggeration of the real Vitalism in its narrower sense that moved Lotze to reject as a whole what he yet accepted in part; though, as in the case of Kant, fictitious problems created by a mechanical dogmatism were not without their pernicious influence.

\section{(b) BERNARD.}

To Claude Bernard is due the other important critique of the older Vitalism. It has its origin in the seventies, and is therefore really subsequent to many sporadic anti-vitalistic criticisms which we shall mention in due course ; but we shall nevertheless deal with it here so as to preserve a certain unity for the little really profound criticism which exists.

Many chapters of Bernard's Leçons sur les phénomenes de la vie ${ }^{1}$ are devoted to bio-theoretical discussions of the most general character; we will expressly concentrate our attention upon the historical excursus in the second volume which contains valuable matter concerning the history of biology in the sixteenth and seventeenth centuries.

Bernard, like Lotze, is for the most part tilting at windmills, i.e. what he attacks was indeed once said by some exponent of Vitalism-chiefly by Bichat-and it generally deserves his strictures: but for all it was not really the Vitalism.

${ }^{1}$ Paris, 1878-9, 2 vols. 
Who, for instance, conceived of vital phenomena as "régies directement par un principe vital intérieur" without dependence upon external conditions? Certainly not Wolff, Blumenbach, or Liebig. Who imagined only "l'intervention d'une force extraphysique, spéciale, indépendante" ? Surely only a few.

But Bernard does not confine himself to criticism of exaggerations of the vitalistic doctrine, and when he is occupied with the real theory he finds himself to a certain extent in agreement with it.

" Nous nous séparons des Vitalistes, parce que la force vitale, quel que soit le nom qu'on lui donne, ne saurait rien faire par elle-même, qu'elle ne peut agir qu'en empruntant le ministère des forces générales de la nature et qu'elle est incapable de se manifester en dehors d'elles.-Nous nous séparons également des matérialistes; car, bien que les manifestations vitales restent placées directement sous l'influence de conditions physico-chimiques, ces conditions ne sauraient grouper, harmoniser les phénomènes dans l'ordre et la succession, qu'ils affectent spécialement dans les êtres vivants."

"Il y a dans le corps animé un arrangement, une sorte d'ordonnance que l'on ne saurait laisser dans l'ombre, parce qu'elle est véritablement le trait le plus saillant des êtres vivants." The word "force" is not a good designation for what is meant, " mais ici le mot importe peu, il suffit que la réalité du fait ne soit pas discutable."

"Les phénomènes vitaux ont bien leur conditions physico-chimiques rigoureusement déterminées; mais en même temps ils se subordonnent et se 
succèdent dans un enchaînement et suivant une loi fixés d'avance.". . . " IIl y a comme un dessin préétabli de chaque être et de chaque organe."

From the teleological point of view this is clearly thought out, but it still leaves room for the two alternatives of teleology, the static and the dynamic. Did Bernard see this question quite clearly, or was he still troubled by a certain obscurity which even Kant had perhaps not quite fathomed?

Bernard allows a "plan organique," but not the "intervention d'un principe vitale." This last, a "force vitale," is to be admitted at the most as a "force législative," but not as a "force exécutive." This sounds like static teleology.

But then follows the passage: "La force vitale dirige des phénomènes qu'elle ne produit pas; les agents physiques produisent des phénomènes qu'jls ne dirigent pas." This might be taken in a vitalistic sense.

For the more thorough understanding of Bernard's real view, we must consider a chain of argument where he appears, as it seems to us, at his best, and in which he at least approaches the modern phenomenalistic school as represented, for instance, by Mach.

Every science, says Bernard, including, for instance, optics or electro-dynamics, knows only the conditions ("conditions physico-chimiques") under which the modes of appearance which it is studying manifest themselves; it knows only the "déterminisme" of the phenomenon. In the place of the ancient cause appears this view, that certain conditions produce the "phénomène."

If the phenomenon is ascribed to a "force" (force), 
then this latter is always "metaphysical"; it is only "thought," is never " active." The "causes premières" are "inaccessibles."

And-in this meaning of the words-the physiologist should study "le déterminisme physicochimique correspondant aux manifestations vitales."

Is that not Vitalism? In connexion with the above explanations, Bernard reproaches the Vitalists with having denied this "déterminisme" ; but apart from the fact that to many, e.g. Blumenbach and Wolff, this certainly does not apply, we may askis that all he can charge them with? In that case, Bernard could be described as a critical Vitalist.

"Il y a des conditions matérielles (physicochimiques) déterminées qui règlent l'apparition des phénomènes de la vie. Il y a des lois préétablies qui en réglent l'ordre et la forme." "La vie n'est ni plus ni moins obscure que toutes les autres causes premières."

We cannot, however, be satisfied, in spite of all that has been said, that Bernard's attitude to the problem of life is thus finally settled, and we shall have to leave it at this, that he did not distinguish the two sides of teleology sufficiently sharply. In one place he says, "conditions organiques" instead of "lois préétablies," which manifestly sounds more in harmony with a mechanical theory. He claims, moreover, with Leibnitz, that one should study life "as though" no vital force existed; though it is hard to see why.

When, on the other hand, it is said that life is indeed a "principe" but not a "resultante" of the "conditions," this again sounds vitalistic. 
In short, Bernard's standpoint, in spite of the value of certain of his individual contributions, is not in our opinion entirely unambiguous. And this is due to his faulty analysis of the only possible meaning that can be attributed to knowledge of natural phenomena in general.

The last words with which at the close of the second rolume he once more sums up his " vitalisme physique," still leare the actual "vitalistic " element of this Vitalism in the dark-"l'élément ultime du phénomène est physique; l'arrangement est vital."

This would be static teleology of the purest sort had not Bernard proffered that admirably clear argument about conditions and manifestations; and it is on the ground of this argument that we can pronounce him a true Vitalist, who is only to be charged with inconsistency in relation to his choice of many expressions-perhaps because he did not see quite clearly the distinction between static and dynamic teleology.

Thus, criticism of the (partly misunderstood) older theory led our critic himself to the enlightened Vitalism.

If in conclusion we turn to some of Bernard's more specific contributions, especially his discussion of the development of animals, here again a vigorous struggle for clearness without complete success will be apparent. Bernard possesses a clear conception of what W. Roux nowadays calls self-differentiation; he knows that the parts of the embryo derelop in relative independence of each other. Since all processes of life, like everything else, occur of 
necessity, so on the ground of this " self-differentiation," when one of the parts is disturbed, we get the " necessary but illogical " monstra. Here we find Bernard's thought closely allied to that of Lotze.

It is in uniformity with the above that Bernard compares morphogenesis, the growth of individual forms, to the work of a great factory in which those who work at the parts of a product know nothing of that product as a whole. Then, one would like to say, the "whole" does exist in some active form or other? And again, the morphogenetic laws are described somewhat obscurely as "dormantes ou expectantes," but not as active. And yet in every kind of regeneration the organism must be regarded as an "ensemble ou unite," and the organic form is expressly regarded as not being the result of the nature of the protoplasm : "La forme et la matière sont indépendantes, distinctes."

Thus, the analysis of Bernard's views on specific problems appears to confirm the impression derived from our discussion of the more general section of his work.

(c) THE MATERIALIST-DARWINIAN TENDENCY.

Four circumstances fundamentally determined the character of all thought about nature, and indeed on many other problems, in the second half of the nineteenth century.

First of all, the rise of a materialistic Metaphysic in express opposition to the idealistic identityphilosophy.

Then Darwinism, which explained how by throwing stones one could build houses of a typical style. 
Thirdly, the discorery of the law of the Conservation of Energy by Robert Mayer-a proposition which in spite of the porerty of its content enraptured all the natural sciences.

Lastly, and of particular importance in reference to Biology, the discovery and systematic investigation of the delicate structures of living beings with the help of improred optical instruments.

We may regard these four influences as independent, although they mutually strengthened one another. In relation to the fundamental problems of Biology, and in particular to Vitalism, each should be considered on its own merits.

The materialistic metaphysic of Moleschott, Vogt, and Büchner asserted all that is real is motion, that qualities of a higher kind exist only as appearance.

Darwinism claimed to show how something purposively constructed could arise by absolute chance ; at any rate, this holds of Darwinism as codified in the seventies and eighties. Darwin himself (as is well known) had, to begin with, left the question of the nature and measure of "variability" open; a course which reduced his doctrine to the self-evident proposition that what was not capable of existence could not exist ("Natural Selection"), but yet did not render it obriously meaningless. ${ }^{1}$ Already, however, the single fact that there are possibilities of regulation, such as that seen in the regeneration of the salamader, confutes, as is well known, the

${ }^{1}$ The modern mutation theory of de Vries, which makes variations arise by leaps and natural selection merely do the work of elimination, is, of course, not Darwinism. Darwin was nearer to this view at the beginning of his career than later. 


\section{MATERIALIST-DARIVINIAN TENDENCY}

orthodox Darwinism of Darwin's followers, for, in its application to this case, the scheme becomes utter nonsense. This cannot be too often emphasised, and none of the other refutations of Darwinism equal in drastic incisiveness that based upon the facts of regeneration.

Concerning the Law of the Conservation of Energy, it was not realised that it was only the law of causality interpreted quantitatively.

But the discovery of the delicate structure of microscopic organisms played the investigators exactly the same trick as had their former ignorance. Formerly much had been accounted for as the operation of an ultimate law of life, simply because it was not known that there were very many complications of a mechanical kind which would have to be accounted for before any general explanation was attempted. Now, because a few things were really understood on account of the delicate structures having been recognised, it was thought that everything must be comprehensible on the same grounds. This, however, readily opened the doors to a dogmatic mechanical theory.

The effects of the general conditions which we have described varied considerably in the different branches of Biology. Botany allowed itself to be the least influenced; it has preserved its continuity, and on the whole even in this time of depression remained a science. In the sphere of animal life, in Physiology proper, the doctrine of the functions did occasionally break loose and wander into blind alleys, but never actually degenerated. The thorough training of its representatives, together 
with the circumstance that as a fairly severe discipline it could permanently retain only the most gifted minds, spared it from such a fate.

But Animal Morphology celebrated a perfect witches' orgy. It elaborated a phantastic construction of so-called "genealogical trees."

The idea of a genetic connexion of the different specific life-forms, the idea of a "Descent," had made its appearance, as is well known, already in the eighteenth century and even in Antiquity. But it had always been brought forward in a general and problematic form with the consciousness that here nothing positive could be said ; and far-seeing persons, philosophers especially, had realised that historical information could never constitute an explanation, and that in comparison to real science it was of very secondary importance. ${ }^{1}$

But now Darwinism had apparently "explained" Descent in general, ${ }^{2}$ why should it not "explain the pedigree of individual species"? And so the old comparative anatomy, which claimed to be nothing but a classificatory preparation for the knowledge of the type, of the rational in the forms of nature, became the phantasy christened Phylogeny.

${ }^{1}$ Cf. Hegel, Kleinc Logik, ed. Bolland, Leyden, 1899, p. 522, and Schopenhauer, Will in Nature, ed. Frauenstädt, fifth edition, Leipzig, 1891, p. 44. The two opponents are here united. I may refer the reader also to my work Die Biologie als selbständige Grundwissenschaft, Leipzig, 1893, 2nd ed. 1911. The problem of history cannot be discussed here ; it is dealt with in my Gifford Lectures.

2 The doctrine of Descent and Darwinism must of course be kept distinct; the latter, which in its orthodox form we regard as finally disposed of, is a subdivision of the former, which appears probable in view of the results of Palaeontology and Geography, though its laws are still very obscure. 
Far worse were the "laws" whose discovery the occasion facilitated. What was called "general zoology" was here the chief playground for their fabrication-which simply violated every principle of the formation of scientific concepts. Wigand has given a classic description of this state of affairs which is not lacking in humour.

But we must not dwell any longer upon these matters which do not really concern the history of Vitalism, and the analysis of a single example will suffice to show the depths to which the sense of scientific method had fallen. For the Darwinian Phylogenists all construction of form was accidental ; consequently, the totality of living forms of life appeared to them as meaningless as, say, the forms of clouds in their accidental peculiarity. But this at once did away with any deeper meaning for zoological classification. It was settled once and for all ; the question had no sense. And yet it was investigated-though by imaginary means. But why? How could one spend one's strength on a task of the scientific worthlessness of which one was convinced from the beginning as a thoroughgoing Darwinian? 1 The obvious answer is that no one put to himself the all-important query-what after all is the meaning of science itself ?

It was, on the one hand, the Physiology of formconstruction which originated in $\mathrm{His}$, and was materially advanced by Roux, and, on the other,

1 Darwin is unfortunately always made to suffer for the sins of his followers, and the words "Darwinism," "Darwinian" are quite established. Darwin himself, though not always critical, kept clear of the chief errors of "Darwinism." 
the exact researches made upon variations, hybrids and mutations, which began to put an end to the unworthy state of zoology which we have described.

If we turn once more to our central thesis, the position of Vitalism in the light of the sciences in general, it is clear that the attitude of the representatives of the scientific spirit of the last generation will be one of absolute negation. There was no place in the chance-theory for a deeper interpretation of the forms of life even in a merely static-teleological sense.

We will indicate the attitude of that period to Vitalism by means of two examples; the views, namely, of two of the best thinkers of the age whose positive scientific achievements, in spite of their subservience to the ruling tendency, are certain of a fame which will last through generations. If we find the statements even of such writers astonishingly hasty and superficial, we shall be forgiven for passing over in silence the great mass of contemporary deliverances on the question of the independence of vital events.

Emil du Bois-Reymond dedicated to the refutation of Vitalism the greater part of the Introduction to the first volume of his Untersuchungen über tierische Elektrizität (Berlin, 1848).

He is entirely caught in the trammels of mechanical Physics. It is from this dogmatism that later his famous "Ignorabimus" sprang, his assertion, namely, that man would never be able to grasp "how matter could think" : a problem which a real critique of knowledge simply solves by the consideration that " matter" does not " think." 
Starting from his standpoint of mechanistic investigation of nature, Dubois begins in the usual way by quarrelling with the term "life-force." Force is never the cause but only the measure of movement. As we already know, however, the dispute is merely verbal.

He then endeavours to show in succession that neither a special matter nor a special force of the ultimate particles of matter-to which alone the word force in its meaning of measurement can here be applied-are at the base of the phenomena of life.

"A particle of iron is and remains one and the same thing whether it travels through the celestial spaces in a meteor stone, crashes along the rails in the wheel of an engine, or courses through a poet's temples in the blood-cell."

In this resounding sentence the specificity of living matter is rejected, but unfortunately by means of an assumption of which it is and remains true to say that it is in the worst sense metaphysical and devoid of any clear meaning.

This, however, is not so important. We have still to refute the assertion that the specific criterion of vital processes is not to be found in the difference between the forces of the material particles in organic and inorganic bodies. Here, says our critic, there is no difference. "There is no life-force in the vitalistic sense, because the operations ascribed to it can be analysed into those which proceed from the central forces of the particles. There is no such force because forces do not exist independently and cannot be arbitrarily allotted to and then removed from matter." 
In answer to the first objection, one can only regret that the author did not carry out the analysis in question. He, at any rate, cannot be assumed to have succeeded.

The second sentence, however, first affords a support to Vitalism, and then attacks this support. It would have been better to have asked: Do the facts compel us to assume that the phenomena of life have a law of their own, or do they not? And of the proof of the negative we find in Dubois literally not a trace.

That a life-force would contradict the law of the conservation of energy forms the conclusion of $\mathrm{E}$. Dubois Reymond's statements. We shall have a better opportunity of testing this supposed objection if we now turn to the opinions of the second of the writers whose views we proposed to examine.

Helmholtz shall be our second example of an opponent of Vitalism in the materialistic reaction. We can fortunately be brief even as he is brief. Indeed, he hardly deems Vitalism worthy of consideration at all.

With the assumption that Vitalism had regarded freedom in the sense of a negation of law, the famous physicist introduces the problem of Vitalism in many parts of his writings on general subjects. ${ }^{1}$ But had this view of freedom, or even anything similar, been maintained by any Vitalist? And had not Blumenbach and Wolff, for instance, expressly asserted the contrary?

${ }^{1}$ Cf. the Vorträge und Reden, third edition, Braunschweig, 1884. 
Vitalism, it is said, contradicts most clearly of all the law of the Conservation of Energy.

"If the Life-force could momentarily suspend the gravity of a body the latter could, without expenditure of physical energy, be raised at pleasure to any height, and then, when its gravity was restored, be rendered capable of accomplishing any amount of work desired. If the Life-force could momentarily abolish the chemical attraction of carbon to oxygen, then carbonic acid could be decomposed similarly without any consumption of energy, and the liberated carbon would be capable of new work." But we do not find the "slightest trace of the living organism being capable of producing any quantum of work whatever without a corresponding expenditure of energy."

This sounds well enough. Two details only seem to have been overlooked. First, the fact that a bar of sealing-wax to which friction has been applied can temporarily suspend the gravity of, say, little pieces of paper or of little balls of pith. In the second place, Vitalism never asserted anything in violation of the law of the Conservation of Energy, for the very simple reason that no one was yet conscious of its universal validity. But then Helmholtz might object that the law had been unconsciously violated, and that this violation was a necessary feature of all Vitalism. But in that case he could have laid claim to but a superficial knowledge of vitalistic literature? He ought at least to have known the work of Johannes Müller. Yet, as we have seen above, it is precisely Müller in whom we find indications of an anticipation of the 
postulate of a " source of energy" for life ${ }^{1}$ : but who was nevertheless an adherent of the doctrine of the autonomy of life.

Thus, there is not so very much to be said for the refutation of Vitalism on the ground of the law of the Conservation of Energy: and Helmholtz is as incapable as other opponents ${ }^{2}$ of producing any better objections.

We may then repeat at the close of the whole section of our book which deals with the older Vitalism what we said at the beginning of the present chapter. The prevailing Vitalism was not crushed by "refutations" ; most of the critics dealt only with its exaggerations, and their "refutations", did not touch it at all, but only effected certain consequences conreniently attributed to it by the critical imagination. Vitalism died of itself.

That it should hare so died, though still apparently at its zenith-as the doctrine of the schools-is to be explained by a cause that lies particularly deep.

The problems of the physiology of morphogenesis had already, since the beginning of the nineteenth century, lost their hold on the interest of biologists. But these problems are the peculiar province of Vitalism, whence alone it really derives

${ }^{1}$ In the second part of this book we deal with the facts of the relation of life to energy.

' Here we may mention Karl Ludwig, who in the first volume of his Lehrbuch der Physiologie des Menschen (second edition, Leipzig and Heidelberg. 1S5S) rejects Vitalism and refers to Dubois. But he is far from adopting the definite tone of Dubois. He makes certain "clear demands" of Vitalism and rejects it as unable to satisfy these demands; though had this not been the case he declares that he would never oppose the hypothesis, howerer novel the arguments used in its farour. 
its strength, at least in so far as it does not also claim the "soul" as its object.

The New Vitalism, to the consideration of which we are about to turn, arose, in conformity with what has been said, mainly as a result of the newly awakened Physiology of development.

We may, in conclusion, say a few words with regard to the state of psychology during the decline of Vitalism. Psychology, as soon as it studies the behaviour of men as phenomena of movement and seeks to establish laws, must come strictly under the heading of Natural Science, and even of Biology -and it is, therefore, both characteristic and comprehensible that the doctrine of so-called psychophysical parallelism flourished contemporaneously with materialistic science during the decadence of Vitalism.

Human action was thus also subordinated to the general materialism; any natural event in it was a mechanical event. A "soul," or whatever name we like to choose, is not an element in the causality of nature. ${ }^{1}$

Johannes Müller, and even Lotze, the opposer of vegetative Vitalism, had thought otherwise on this question of man's behaviour.

1 This is a suitable place to mention the original contribution of E. Hering: Über das Gedächtnis als eine allgemeine Funktion der organisierten Materie (Vienna, 1876). Hering had an open mind, which allowed him to see in memory and in the capacity for reproduction something analogous though very strange. But he was too much influenced by the parallelistic theory to be able to say: there is something new, something not inorganic here. Hence, all his psychological expressions are only metaphorical, and natural events are always really interpreted from the materialistic point of view. 
Everything connected with Psychology will have its place in this book only in an accessory manner, and will concern us only when it is turned to account by its representatives in a general, bio-theoretical form ; it will, therefore, be as a side-issue that we shall later on have to explain how with the awakening of Vitalism there went, to use terms not very accurate but yet intelligible, an awakening of "psychophysical causality." This, however, implies the downfall of the theory of psycho-physical parallelism. 


\section{CHAPTER III.}

MODERN VITALISM.

\section{THE TRADITION.}

A TRUE doctrine is never completely extinguished. It may for a time be out-shouted by its opponents, but there are always a few who, whatever may befall, pursue their way, heedless of all the uproar of the day. And indeed, things were not pleasant for the few who, when materialism was at its zenith, guarded the tradition of the old, i.e. of the vitalistic biology. People would have preferred to have locked them up in madhouses, had not "senility" " excused" them up to a certain point.

Thus it was that in spite of all opposition, the tradition of Vitalism was handed on. And-apart from botany, which always remained intact-there was also preserved, at any rate by a few, the tradition of a method of animal morphology which set out not merely to "compare," but also to establish laws.

The Darwinian school studied the construction and development of animals only so as to compare them one with another, and to concoct genealogical 
trees with the help of their comparisons. Their work was historical. But the old morphology had sought by means of anatomy and embryology to establish the laws, if any, which actually controlled morphological phenomena. It sought, in fact, to discover what morphogenesis really was. It sought, moreover, to construct what was typical in the varieties of forms, into a system which should be not. merely historically determined, but which should be intelligible from a higher and more rational standpoint.

It is to the lasting credit of the late Wilhelm His that he kept alive at any rate the principle of this method of truly rational morphology; and the work of Alexander Goctie should not be forgotten. It was to these writers that the later "Mechanics of. Development" attached itself, with its claim that morphology should take its place amongst the real sciences.

His and Goette had recognised that the true processes of morphogenesis which appear in the development of the individual require actual and efficient causes for each single realisation. But it was just this condition, without which no laws of formation could be scientifically established, that adrocates of phylogenesis had overlooked. They allowed " heredity" to stand as the cause of morphogenetic processes, a theory which exhibited in a new and aggravated form the same logical weakness as that theory of the old nature-philosophy which allowed the ideas to be sufficient grounds for the organic form. In both cases the link was missing which should unite the general to the particular. 
But to resume: the next among the writers who handed on the real Vitalism, or at least a teleological conception of forms of life, was the aged Baer, who again and again in the sixties and seventies put forward his view in speeches and lectures. ${ }^{1}$

It did not contain much that was new, as the part which Baer played in the old Vitalism was a secondary, or rather a dependent one. But small as it was, it was good that his contribution should have been made. In all his teleological exposition, Baer enters the lists as an opponent of Darwinism, and we may say here once and for all that all who during the ascendancy of materialism preserved the vitalistic tradition, were at the same time opponents of orthodox, i.e. materialistic, Darwinism. Indeed, it was in its opposition to the theory founded on chance that the tradition maintained its strength.

Baer's treatment of the subject strikes us now as brilliant rather than precise, and it is hard to have a very definite conception of what is meant when we learn that he regarded the life-process not as the result of the organic construction, but "the rhythm and also the melody to which the organic body constructs and transforms itself." The definition also of the life-processes as " creative thoughts which build up their own bodies of themselves," and his likening of type and specificity to "harmony and melody," are still only metaphors.

$\mathrm{He}$ is far more explicit in regarding the impulse as " something primitive, i.e. which does not proceed from the bodily constitution but stands over and

${ }^{1}$ C. E. v. Baer, Reden und Abhandlungen, Braunschweig, second edition, 1886. 
above it" as "a completion of the life-process." In a happy phrase he calls "conscience" the " highest form of instinct."

$\mathrm{He}$ is obscure again where he describes the controversy about the life-force as "futile" ; and Blumenbach's "nisus formativus" is not very aptly placed on the same plane as the "faculties" of a Fabricus ab Acquapendente, ${ }^{1}$ the fabrication of a barren schematism. That Baer has in view a true Vitalism and not merely one of static teleology, although he does not see the fundamental distinction between them, is quite clearly shown by the statement that "the whole life process is in no way the result of physico-chemical events, but rather controls them." For him life is a process with peculiar laws of derelopment. Exception might be taken here to certain details in the wording.

Of Baer's other contributions we need only mention that he corrected the so-called "biogenetic principle" of the Darwinians by pointing out that the history of development indicated only the "transition from general to more specific relations, but not the transition from one specific relation to another." He expressed an exactly similar view upon this important point when he declared that as an embryo man does not pass through the fish stage, but man and fish both pass through the same general, less specified stage.

Human actions, the "life of the soul " objectified,

1 The teacher of Harrey. He held that three processes, generation, derelopment and nutrition, are required for the production of a chicken. Each process needs two forces. Thus, we get six faculties-immutatrix, formatrix, attractrix, retentrix, cuicentrix, expultrix. 
cannot, according to Baer, be analysed in terms of matter, as is maintained in the doctrine of parallelism; they represent an elementary autonomous fact. In quite modern phraseology Baer points out how, for instance, the effect of one and the same piece of news differs completely in the case of different persons, according to their previous history.

So much for the vitalistic conception as maintained by Baer in spite of all attacks and misrepresentations. Its existence is important to the history of Vitalism, even though it has not added to our actual fund of theories. Baer, a writer of high repute owing to his services in the realm of embryology, could indulge in his Vitalism without actually incurring abuse. In the same way it was even tolerated when a man like the founder of cellular pathology occasionally stated that he was not really quite convinced of the possibility of the mechanistic interpretation of all lifeprocesses : though it is true that Virchow's theories, as also later the statements of his follower Rindfleisch, move only along the most general and accepted lines.

$J$. $v$. Hanstein ${ }^{1}$ again was excused for disloyalty to the spirit of the age on the ground of his service in another field. He was still more definite in the statement of his views, though his theories contain nothing new. With reference to formation out of the germ, and contemporary mechanistic theories, he asks : How, in the first stages of construction, does everything come to be rightly divided, since for every formation an initial nucleus must be packed up in

1 Johannes von Hanstein, Das Protoplasma als Träger der pflanzlichen und tierischen Lebenserscheinungen, Heidelberg, 1880. 
the egg? Must there not be organising architects to direct the multitude of mosaic fragments? He rightly adduces in support of his thesis the processes of regeneration. The Aristotelian statement that the whole is prior to the parts, still holds good, he says, to-day.

Organisms are controlled by a faculty of selfformation, and animals have also a similar power of movement. It is closely connected with the presence of certain material combinations, which it has ordered and controls; it distributes itself among them, and when two or more such material groups unite, then the centres of activity also unite into one.

Here we see how some of the ideas of the old Vitalism are once again timidly appearing.

That Hanstein should subject the theory of Natural Selection to the sharpest criticism was only to be expected; but the man who, though not remarkable as an experimenter, must be regarded as the really classic critic of Darwinism is Albert Wigand. Wigand was not so easily forgiven for his criticism and for his assertion, really a very timid one, of vital autonomy.

I can myself bear witness that even so late as the end of the eighties it was hardly considered respectable to speak of Wigand's great Critique ${ }^{1}$ in any but the most disparaging terms, or to regard the man as other than an utter idiot.

We have here as little concern with Wigand's critical work as we have with criticism of Darwinism in general. We have to do with the positive element

1 Darwinismus und die Naturforschung Newtons und Cuviers, 3 vols., Braunschweig, 1874-7. See particularly vol. ii. chapter 3. 
which is to be found in his achievement, and we must at least briefly refer to the fact that his criticism of the scientific formation of concepts exhibits great independence, and raises him entirely above the verdict of tradition. I would designate Wigand as the first exponent of that scientific criticism of concepts which was later founded systematically by Mach. Let us not forget at this point that Schopenhauer, and in certain respects Blumenbach, had in reality also been precursors of the new tendency.

Wigand's attitude to the problem of Vitalism is clear from his epistemological position. The question whether there is a life force by means of which we can explain vital phenomena, which is unique, and does not operate in the rest of nature, is to be answered partly in the affirmative, partly in the negative. In the affirmative, if force is to mean nothing more than what the words electricity and gravity mean; in the negative, if there is meant a supernatural principle independent of the universal laws of nature, which does not manifest itself through the law of cause and effect.

Even in the former sense the life force would not explain anything - any more than those other forces which also are only names for some "qualitas occulta" ; indeed, it accomplished rather less, owing to the lack of any quantitative import. In any case we may at least admit a life force, so long as all the known agencies fail to explain life.

It is clear that Wigand does not approach the actual question of the proof of "Vitalism" at all, 1

1 I cannot forbear quoting an apposite passage from Zöllner's Natur der Kometen (1872), which Wigand cites : "The assumption 
but he expresses himself more definitely on the subject of teleology in the organism in general, and in indicating the large amount of static (mechanical) teleology which is actually to be found in the construction of the organised being, e.g. of the eye. This necessarily constitutes the main point in his critique of Darwinism, since it is just the purposiveness in a complex organic formation which makes the theory of chance appear so absurd. The question of Vitalism could here afford to step into the background.

Wigand succeeded as little as the other traditional Vitalists whom we have mentioned in exerting any influence upon the thought of his time. Perhaps the attitude which they adopted was too tentative; perhaps the ground was all too unprepared in the seventies; perhaps their time was not ripe.

This last supposition is rendered more probable when we consider the attention aroused about the year 1890 by views in reality far less clearly defined with regard to Vitalism than any of those previously mentioned. I refer to the writings of G. $v$. Bunge. Indeed, even the obscure utterances of Rindfleisch, buttressed as they were by the theological point of view and undeserving of a closer examination here, succeeded in attracting the attention of the public. Times evidently had changed.

In his essay "Mechanism and Vitalism," 1 which

of a new property of matter would only be necessary when it had been logically proved that in the nature of the phenomena conceptual elements were involved which were not in the properties hitherto attributed to matter and which cannot be deduced from it."

1 The first section in his Handbook. 
he later changed without advantage into "Mechanism and Idealism "-and into which he quite illegitimately, from the standpoint of theory of knowledge, introduced psychological questions-Bunge is very far from making a decisive stand for Vitalism.

But it is all only provisional, only an admission that the mechanistic conception is "not yet" sufficient. Indeed, it is Bunge who, when face to face with the most complicated of all the facts adduced by him as still unexplained, says: "I admit unconditionally the possibility that some day all those phenomena will find a purely mechanistic explanation." Thus we have here a thoroughly problematic Vitalism with even an inclination to the opposite view.

In truth, that Bunge should have been unhesitatingly accepted as a Vitalist shows how extraordinarily alien to the times was the whole conception of the vitalistic problem; it shows, on the other hand, that now at last it was being realised that there might, problematically at least, be something more than materialistic dogmatism.

For Bunge had not taken sides with Vitalism any more decisively than, for instance, His, when the latter left it undecided at the outset whether any part of the earlier content of the conception of the life force could be resuscitated in a formula more precise and in a terminology more suited to the age.

But Bunge had led us within sight of the most recent phase of our subject. We have dealt with him here because he at once belongs to, and yet in a certain sense cuts himself off from, the line of the other German upholders of the vitalistic tradition. 


\section{THE POSITION OF PHILOSOPHY.}

We must now turn back for a moment, in order to form an estimate of the philosophy of the seventies and eighties as regards the Vitalistic problem.

\section{(a) EDUARD VON HARTMANN.}

The fact that we now propose to examine the attitude of philosophy towards Vitalism, and head our first section with the name of Eduard von Hartmann, might give the impression that we regard Hartmann as typical of the new philosophy.

Hartmann is, as a matter of fact, anything but a typical representative of modern philosophy, but he is the only modern philosopher who comes into consideration for the problem of Vitalism. According to the plan of our work Hartmann's metaphysic of the Unconscious concerns us as a system just as little as the Rationalism of Hegel or the Volitionalism of Schopenhauer. It must suffice to state that Hartmann's whole philosophy is biological, i.e. is based upon biology, but that, with regard to morphogenesis, the so-called instincts, and the relation between psychical and physical in the actions of man, he construes biology in every respect as Vitalism. 
Only two trains of thought in Hartmann's philosophy are of immediate interest to the historian of biology as natural science.

One of them is purely conceptual and connected with the metaphysical scheme of the universe constructed by the philosopher: factors of consciousness are with him opposed to factors of the unconscious; but between these two principal factors there may be causal relations of a four-fold kind. Causal relation between factors of the same group Hartmann calls isotropic causality, and allotropic causality is its opposite. As the higher living beings consist of factors of both kinds and constitute "individuals," we get the conceptions of intraindividualist and interindividualist causality. Consequently, the so-called "psycho-physical causality," which with Hartmann takes the place of "psycho-physical parallelism," is allotropic intraindividual causality ; between two individuals there takes place directly, as far as we have definite knowledge, ${ }^{1}$ only interindividual isotropic causality, and this in the unconscious sphere.

We may close this introduction with the remark that Hartmann's point of view is that of "critical realism," and not the strictly idealistic standpoint from which we are considering these problems. This leads us on to examine his opinions concerning the action of the vital factors of life in the system of the material factors of the organism : for his fictitious realism, which makes the whole of the material

1 Telepathic action would, of course, imply either interindividual isotropic causality in the field of the factors of consciousness, or interindividual allotropic causality. 
factors ultimately the work of a real mechanical system, renders it necessary to investigate this action.

What we describe simply as material factors, Hartmann calls strictly " materiant agents," i.e. agents which bring about the appearance of the material. Now all such agents have a potential and are divisible into central forces. But the life-agents are not "materiant agents" and have no potential, nor are they combinations of "central forces." How can they work upon the totality of the material system without destroying the so-called principles of energy which constitute the foundation of all that happens in it, and ret be in opposition to the inorganic which for Hartmann's mechanical realism is nothing but mechanics?

Hartmann's theory is of special importance for the history of Vitalism, because it is the first attempt to make a precise application of the doctrine of the autonomy of life, namely, to make out exactly the relation of the elementary life-factors to the factors of the inorganic. ${ }^{1}$ So he gives to a theoretical consequence of Vitalism a scientific content. But Hartmann's theory touches less upon Vitalism as a question of fact. He offers no rigorous demonstration of the impossibility of a mechanical solution of life.

A metaphysical conception, not an investigation of details, constitutes the real centre of Hartmann's philosophy; and we may conclude our remarks by recording that this philosopher, whose fruitful career has recently been brought to a close, saw in

${ }^{1}$ This endeavour is not found, as was assumed, in certain passages in Maxwell and Helmholtz (see Driesch, Naturbegriffe und Natururteile, Leipzig, 1904, p. 102 ff.). It is, however, implied in some expressions of Lord Kelvin and of L. Boltzmann. 


\section{EDUARD VON HARTMANN}

" finality," in opposition to Kant, a pure Category ${ }^{1}$ which has its place by the side of substance and causality.

(b) OTHER PHILOSOPHERS.

We have said that Hartmann is almost the only philosopher of the last decades who comes under discussion in a history of Vitalism; indeed, we should like to make mention of only one other representative of general philosophy-Otto Liebmann.

With the exception of Hartmann, Liebmann is almost the only modern "philsopher" who has entered on a critical discussion of the problems of life, and emancipated himself from the mechanistic dogmas of Darwinism. Though he does not prove Vitalism, yet he at least regards it as a possibility, and he sees, for example, the historical importance of an Alexander Goetle; he at any rate has doubts where the theory of the age gave no possibility of certainty.

Liebmann's entirely critical treatment is unsuitable for a short summary. ${ }^{2}$ We will merely refer to his characteristic predilection for the Aristotelian expression "Entelechy," which was also used by Goethe and occasionally by Baer.

\section{(c) PSYCHOLOGISTS.}

Vitalism becomes a much wider problem when we include in it the question of what is the relation of the soul or mind to nature. But it has been our

1 Kategorienlehre.

${ }^{2}$ Compare my article in Kantstudien, xv. 1910, p. 86. 
principle so far to consider the problem of psychophysics only in those cases where psychological writers themselves have seen the general importance of their theories, as was the case, for instance, with J. Müller.

Modern writers have rarely if ever connected Psychology with the vitalistic problem. Hardly any have ever recognised the close relation between the problem of mind and body and real Vitalism. It is strange that not even physiologists like Pflüger and Goltz have seen this close connexion. I am not thinking here of Pflüger's Teleological Mechanics, ${ }^{1}$ where the teleology was purely formal, and really said very little with its statement that every need is the cause of its satisfaction; but rather of his theory about the "Rückenmarksseele "- the faculty of the spinal cord of frogs, deprived of their whole brain, to react to stimuli in a manner which resembles action. In the case of Goltz I refer to the conception of the "Antwortsreaktion"-the capability of reaction in frogs deprived of the hemispheres but possessing more of their central system than the mere spinal cord - which was based on his endearours to locate the soul of the frog. ${ }^{2}$ Pflüger claims to have shown for the functions of the spinal marrow, and Goltz for those of the so-called lower braincentres, that their complication and their free rariability is too great for a machine to be assumed as their basis. Hence, we must adopt an animistic view.

${ }^{1}$ Bonn, 1877.

2 Beitrüge zur Lehre von den Funktionen der Nervenzentren des Frosches, Berlin, 1869. 
Here we have Vitalism pure and simple. It is very strange that like Lotze, neither Pflüger nor Goltz are clear in their minds that for a part of vital phenomena at any rate this view implies a theory of the autonomy of life, and the rejection of psychophysical parallelism.

If we pass from the theories of the physiologists Pflüger and Goltz to the theories of the psychologists, it is, as we said above, the question of parallelism which concerns a history of Vitalism. It must suffice here to say that although psychological parallelism is still the prevailing theory, the voices of those (even apart from v. Hartmann) who support psycho-physical causality are growing ever louder. We may mention Busse ${ }^{1}$ as one of the latest type of psychological champion of this view, and those who wish will find in his writings an account of the most recent German ${ }^{2}$ literature on this subject.

\section{(d) EDMUND MONTGOMERY.}

The American biologist and philosopher who, though originally a physician, for many years dedicated a quiet life in the south of the United States to the study of the principal problems of life, is still comparatively unknown.

We cannot say that Edmund Montgomery really discovered a new foundation for Vitalism, and we have therefore ranged him with the vitalistic philo-

${ }^{1}$ Geist und Körper, Leipzig, 1903.

${ }^{2}$ In France Henri Bergson (Matière et Memoire) is the chief advocate of psycho-physical causality ; in England, W. MeDougall (Body and Mind); see also vol. ii. of my own Gifford Lectures. 
sophers of the last decades. He has, however, treated the whole problem of vital autonomy so originally, with such a peculiar combination of science and philosophy, that we believe he deserves individual consideration. ${ }^{1}$

In spite of the work of Kant and Berkeley, Montgomery adopts a metaphysical realism, and it is this realist Metaphysics that makes possible his solution of the problems of the ego and of the individual organisation.

Sense-experience does not remain to us a mere mosaic of elements, but it becomes integrated bý synthesis, it becomes a complex unity. The bodily organism on the other hand, is an indiscerptible whole, not a divisible aggregate. The solution of both problems alike lies in a rightly formulated concept of substance. As a result of his realistic metaphysics Montgomery imagines his substance as a specific chemical combination after the manner of Reil ; but from the specificity of this life-substance he arrives at special new laws. The combination as such, which certainly is not regarded

1 From the point of view of Vitalism the principal writings of Montgomery are: "The Substantiality of Life" (Mind, 1881, p. 321); "On the Theory of Muscular Contraction" (Pflüger's Archiv, 25, 1891) ; "To be alive, what is it ?" (Monist, 1895); Of primary importance for epistomology and psychology are : "The Dependence of Quality on Specific Energies" (Mind, 1880); "The Object of Knowledge" (Mind, 1884); "Mental Activity" (Mind, 1890); "The Integration of Mind" (Mind, 1895): "Are we Conscious Automata ?" (Texas Acad. Sc., 1896), and a few other works. In 1904 there appeared his book The Vitality and Organization of Protoplasm (Austin, Texas, 1904). In 1907 he published his Philosophical Problems in the Light of Vital Organization (New York), which sums up his views on the whole question. 
as a chemical unit, a mere aggregate of separate molecules, has a controlling power over the organisation, as it also realises the synthesis of the manifold in the conception of the ego; it is the identical, indivisible, perdurable, and self-sustaining substance, of which the transient phenomena arising in consciousness are but inherent affections. A certain similarity to Hartmann's views is noticeable here, and an "Unconscious" often appears in Montgomery's works as basis for consciousness.

In matters more properly vitalistic, Montgomery expressly opposes any machine-theory as a basis in itself of organic phenomena; and bases his objection on an analysis of the movement of protoplasm, of the contraction of muscles, of the divisibility of infusoria, and of regeneration in general. It is the life-substance that constantly restores its own integrity, and he is not here thinking of chemical influences of a similar kind at all. Assimilation in a way becomes to him the most important of all biological phenomena, but it is the result of an inwardly constituted autonomy. There are, he says, evidently forces genetically organised at work here, and these forces one can only regard as specific energies.

When we come to expound our own views, it will be seen that we find it impossible to accept either Montgomery's realistic metaphysics, or his vital substance. But this does not diminish his historical importance : he is a Vitalist as regards the principal question, and even uses the word "autonomous." Where he is really original is in his unique method, which, whether it meet with our approval or not, is 
as acutely applied as it is conceived. His method is the endeavour to solve conjointly the two problems of integration, referring the one to the organism and the other to psychic life. But, besides his methods, Montgomery has another claim on our attention, and that is his peculiar recognition and formulation of just those two problems from which, though perhaps in a somewhat different form, every Vitalism must, as a matter of fact, take its start. His formulation of the problem which arises from the analysis of action seems to us particularly happy; but the problem of organisation is not sufficiently analysed for a proof to be possible.

If Montgomery had presented his concept of substance as a category, instead of as a chemical substance, we should have been able to agree with his views almost completely. 


\section{THE ANTI-DARWINIAN THEORY OF DESCENT.}

If we knew more actual facts about the descent of the organism than we do, we should have to analyse in some detail the views which have been expressed about the laws of a phylogenetic evolution, supposing that such really occurs; and we should have to ask if these laws were mechanical or vitalistic.

Since, however, even the most simple facts with regard to descent are purely hypothetical, all the general laws of descent, inasmuch as they represent purely imaginary constructions, are without any real scientific value.

In his theory of mutation, de Vries, like many enquirers into the formation of hybrids and variations, and some entomologists of a quite recent date, has endeavoured to ascertain the actual facts of the derivation of one species from another, and to demonstrate such derivation, at any rate in part, by exact methods. But there is still no question of any real immanent law having been established in so far as a real descent is concerned, that is to say, in so far as it is a question of mutation. 
Hence, we cannot do more than give the names of the supporters of a general non-Darwinian theory of descent under the various forms of law of evolution or of perfection or of organic growth, all of them representing an autonomous and vitalistic law of organic transformation. ${ }^{1}$ This is not an objection ${ }^{2}$ against men like Kölliker, Wigand, Nägeli, Eimer, and others, to whom we must add Herbert Spencer; for their more or less thorough opposition to the pure Darwinian theory of chance was at any rate a valuable service. We may add here the general remark that a view of the problem of descent opposed to Darwinism would be either vitalistic or mechanical : in both cases it would be distinguished from the principle that the species is a product of chance in the Darwinian sense. But at first sight, that is to say without a deeper analysis of the facts than we are at present in a position to undertake, it would be quite conceivable that organic species are not the result of an elementary autonomous law

1 The Neo-Lamarckians, a special group of Anti-Darwinians, of which Samuel Butler was the first representative, will be briefly mentioned later. An immanent evolutionary law is not established by this group of thinkers.

${ }^{2}$ We often find non-Darwinian theories of descent united with theories of ontogenetic development which endeavour to explain matters by imaginary pictures drawn from a pseudo-mechanical source. Even Darwinians, as for example, Weismann, apart from Darwin himself, have imagined a development of this sort, and we need only add the names of Spencer, Nägeli, Wiesner. We cannot here examine these fancy pictures more closely : they are themselves for the most part somewhat confused, and the real problem of Vitalism is only accounted for in a very obscure manner, if at all, in their constructions. For the most part they are only photographs of the problems, and they are well criticised in Montgomery's book, The Vitality and Organization of Protoplasm. 


\section{ANTI-DARWINIAN THEORY}

but of a pre-established configuration of cosmic factors. Those, however, who reject the machine theory for individual morphogenesis will not be likely to admit it as an explanation of descent in a form which has only hypothetical justification. 


\section{NEOVITALISM.}

The newest phase in the history of Vitalism has been termed Neovitalism, though the designation is not quite suitable; for at no time have vitalistic theories completely died out, as those who gave the name and in particular Emil du Bois-Rermond, seemed to imagine.

In a different sense, however, the last epoch of vitalistic thought may be styled new, in virtue, that is to say, of its whole procedure, at any rate as regards the methods of many of its representatives. We may therefore adopt the term.

The norelty in the method is connected, though its authors are not aware of the fact, with the procedure adopted by Vitalism in the eighteenth, and not with the prevailing theories of the nineteenth century. It goes once more back to foundations, and does not only deal with the implications of a doctrine accepted without question. Once more an endearour is made to prove on one ground or another that the vitalistic view of life, and only this view, is necessarily true. In the eighteenth century this resulted from the struggle with materialism; it 
now makes its appearance after the struggle with Darwinism. It is thus due to its enemies that Vitalism once more raises its head. The best opponents of the traditional Vitalism have actually been of direct service in causing its re-birth ; they purified it of many errors and it became all the more clear that there was a kernel of truth at its centre. The cause of the real establishment of Neovitalism was, as we have mentioned, the reappearance of experimental morphology, the "mechanics of development" represented by W. Roux. All new facts which support the theory of the autonomy of life have been won in this field of investigation, with the exception, of course, of those which are derived from the analysis of human action. This is not, of course, quite what the initiator of this method imagined. His conviction of the truth of the mechanical view seems curiously enough to have grown stronger as the years went by: for at the beginning of his experimental work he at any rate left the question of Vitalism open. ${ }^{1}$

For the theoretical development of the logical consequences derived trom the principle of Neovitalism, two considerations are of importance. On the one hand, the new theory of knowledge, in

${ }^{1}$ Cf. W. Roux, Abhandlungen, ii p. 188 ff. : "Whoever does not regard as self-evident and not needing demonstration, which would be a common "petitio principii," what ought to be the final result of our researches, ought to keep in mind in causal investigations into embryology that it is at any rate questionable whether the processes which he observes can be regarded as the result of forces already known; or whether they necessitate special " modes of action" such as differentiating action from a distance and so forth, and thus lead to the assumption of special forms of energy." 
so far as it was original and not a mere repetition of Kant, had given rise to a rigorous subjectivism, which in its turn put an end to a mechanistic metaphysic. And in the second place, the science of inorganic nature had acquired in its best representatives, as for instance in Mach, a special kind of conceptual method, and became conscious that, since it is the business of science merely to describe phenomena, every question of absolute existence is outside its sphere. We shall later have to describe how Neovitalism incorporated the newly acquired body of knowledge, which, however, does not necessitate so complete a rejection of the philosophy of Kant as many modern writers seem to think, but rather tends to justify that philosophy.

In considering Neovitalism from an historical point of view we shall, of course, particularly in this section, have to confine ourselves to what is really typical. It may seem, on first thoughts, that William Roux should be mentioned as the earliest Neovitalist, for he has repeatedly maintained that, at least in functional adaptation, organic development is directly influenced by non-mechanical or psychical factors. He gives as an example the strengthening of the muscles by exercise, in which the psychical factors, the will or the instinct of self-preservation, are essential determining forces.

But Roux never analysed these opinions and never asserted that they directly implied vitalistic forces, even in a restricted field. We shall, then, not be mistaken in holding that Roux merely took over these views as a legacy from certain earlier theorists, in considering him in fact as a "traditional 
Vitalist." In this he is like Lotze who, in spite of his rejection of vegetative Vitalism, attributed all possible functions to the "soul "without seeing that they, too, were expressions of Vitalism.

In $1890 \mathrm{~F}$. Ehrhardt published Mechanismus und Teleologie, a work written, as was usual in the days of the older Vitalism, for the express purpose of proving the logical possibility of a vitalistic conception of life, and emphasising the essential need of its acceptance. The mechanistic theory, which fails in many branches of physics and chemistry is, according to Ehrhardt, far less comprehensive than the causal theory. Teleology is not the antithesis of causality, but subordinate to it. It is, of course, inadmissible to consider "final causes" as implying that an object or end is capable of having effect. No event that has not yet taken place can possibly act. But results are caused by the keeping of the end in view, and it is in this way that the final becomes an efficient cause. These final efficient causes are not in the slightest degree metaphysical, for they derive from organic matter.

This will suffice to show that the method of Ehrhardt's work is of much positive value. The part in which he tries objectively to prove his assertion is weaker, though still worthy of attention. For, if the theory that the will has power to determine action were based solely upon inner experience, and if nutrition and reproduction were to be regarded as expressions of pure vitalistic causality merely because they rest on instinct, it could not have the same weight as when demonstrated by accurate scientific investigation. 
Of much more significance is a thought which Ehrhardt expressed in his polemic against the static teleology of Lotze. He urged that a static conception of the organism must be rejected not only for the minor reason that it did not throw light on the problems of nutrition and reproduction, and only deferred their solution, but also because it failed to take into account the constancy of the vital processes which do not act as if by chance, but are daily producing millions of typical organisms. For the same reason, the mechanical explanations of electricity or magnetism cannot be maintained. Phrsics, too, has its own fixed and constant laws, which, if they had resulted from the combination of more simple natural laws, would most certainly have been fluctuating and only approximately ralid.

It may well be that no evidence of Vitalism will be found in this direction, but the line of thought, at any rate, is original, and, if only for that reason, is worthy of notice. This cannot be said for Ehrhardt's further contributions to positive Vitalism, in which he supports a theory of a sort of rital matter. When certain chemical substances are combined in a special way, they result not only in chemical, but also in specifically organic forces. Although, therefore, this spontaneous generation is actually produced only by chance, the causes of its existence are fixed according to natural law.

Gustar Wolff's excellent critique of Darwinism appeared in 1890, and fully merits its great reputation. In spite of being (without any reflection on its originality) behind the times as a criticism of Dartwinism, it is the first of its kind, arising, as it 
does, from the clear conviction that the fall of Darwinism will bring a simultaneous revival of teleology of great significance.

In the year 1894, Wolff followed his critique by an experiment which was expressly undertaken as a solution of the question: Darwinism or teleology. His aim was to see whether an organism could restore an organ extracted from it for the first time in its development, and to examine how this restitution was accomplished. "Primary finality" was to be proved by the positive outcome of the experiment, which would, on the one hand, reduce Darwinism ad absurdum, and, on the other, through the fact of purposive adaptation, go to support teleology in a very significant form:

The experiment consisted in the extraction of the lens, and nothing but the lens, from the eye of a water-newt (Triton taniatus). A new lens was generated, growing from the outer edge of the iris in a way which, though not corresponding to the ordinary development, ${ }^{1}$ was, nevertheless, most suitable for the purpose in question.

Thus was " primary finality" demonstrated.

Highly though we value Wolff's acute writings, which take a prominent place in modern biological literature, it must be pointed out that although he proved the significance of teleology he failed to demonstrate its methods. His experiment might only point to a pre-established static teleology to be accepted simply as a given fact.

Wolff himself, in the works we have mentioned, never entered into the difference between static and

${ }^{1}$ In the normal development, the lens grows out from the skin. 
dynamic teleology, although he certainly inclined to the latter, that is, to Vitalism. Latterly ${ }^{1}$ he has, it is true, expressed his vitalistic riews more definitely, affirming that much is still inexplicable. I still doubt whether his experiment could in itself demonstrate the methods of teleology.

For the rest, Wolff, in his psychiatric works, ${ }^{2}$ fully accepts the autonomy of psychic life and this, of course, is quite ritalistic.

In 1893, influenced particularly by the methodological writings of Wigand and Paul du Bois-Reymond, ${ }^{3}$ I myself came clearly to see that teleology is an irreducible peculiarity of the phenomena of life. Critical analysis of physiological and morphogenetic phenomena led me to this conclusion. As yet I had not realised the difference between static and dynamic teleology, and my work Die Biologie als selbständige Grundwissenschaft (1893, 2nd ed. 1911), vacillated, without my knowledge, between the recognition of a creative principle and a natural mechanistic teleology. In $1894 \mathrm{I}$ expressed in $\mathrm{my}$ Analytische Theorie der organischen Entuicklung a thoroughly mechanical teleology in the form of different "given" harmonising means, but here, too, I did not perceive that I was pleading for one

${ }_{1}$ Mechanismus und Vitalismus, Leipzig, 1902. In Biol. Centralblatt, 27,1907 , I have answered the objections to my own vitalistic views in the second edition of this work.

2 E.g. Beiträge z. Lehre v. den Sprachstörungen, Leipzig, 1902.

${ }^{3}$ Über die Grundlagen der Erlientnis in den exakten Wissenschaften, Tübingen, 1890. In this work, the independence of every province of physics and chemistry in relation to every other is asserted (compare Schopenhauer), and a similar independence is explained as possible with regard to Biology. 
of two rival teleological possibilities. When I wrote my article on "The Machine Theory of Life" in the year 1896, I was fully aware of this difference. I repeated, in it, the essential substance of the two works mentioned above, for they had in the meantime been misunderstood. I further emphasised the fact that my conclusions had supported not vitalistic but mechanistic teleology, and pointed out that they bore most resemblance to Lotze's ideas upon the vegetative functions of life. ${ }^{1}$ I confronted my static theory with its problematic antithesis, which, though known to be a possible theory of life, had not yet been expressed as such. The conceptions later distinguished as static and dynamic teleology were already to be found in this book, although the words were adopted for the first time in my book on localisation, of which I make mention below.

The experiments of several years upon the power which organisms possess of regulation of form, and continual reflection on the collective results of experiments on the physiology of development, upon which I had been working since 1891, combined with a logical analysis of the concepts of "regulation" and "action," brought about an entire change of my opinions and the gradual elaboration of a complete system of Vitalism.

Already in 1895 I had become convinced, through analysis of the problem of " action," of the necessity of Vitalism. Nevertheless, my first publication was

1 I might also have mentioned Goette, whose Law of Form, which may here be referred to, implied a static teleology. Rostan too, is of this opinion. For further information, ef. Bernard, ii. 
on the vitalistic theory of a separate problem of form-structure, as this subject seemed to me, on reflection, of wider application. The publication to which I allude came out in the beginning of 1899 under the title Die Lokalisation morphogenetischer Vorgänge. Ein Beweis vitalistischen Geschehens. This is the first work in which it is clearly demonstrated that certain at least of the processes of life can only be understood as autonomous, obeying only their own laws-in a word, as dynamic-teleological.

In the work published in 1901 under the title Die organischen Regulationen, I examined in the same way as I had done in my Lokalisation the collective results of the regulative workings of the living body ; in this a new proof was added to my former vitalistic theory.

In 1903 in my work Die 'Seele' als elementarer Naturfaktor, I analysed human action as an objective phenomenon of movement. This was the theory which had been the real outcome of my vitalistic reflections. In the year 1904, under the title Naturbegriffe und Natururteile, I published the methodological justification of my system of thought, and put it into relation with the concepts established in physics and chemistry. In my Gifford Lectures (1907-08) a complete system of Vitalism was formulated, and the logical justification of Vitalism formed an important part of this system. Additions to the logic of Vitalism were made in an article in Kantstudien (vol. 16, 1911) and in parts of my Ordnungslehre (1912). I need not here discuss the contents of these writings, for the concluding 
part of this book will expound them in a concise form as a special system of Vitalism.

In order to appraise the merit of other investigations of the vitalistic question we must go back a few years.

In the year 1899 Paul Nikolaus Cossmann published his Elemente der empirischen Teleologie. which was really complete in 1897. This book specially sets out to frame a logical definition of the concept teleology, and accordingly has several points of contact with Kant's Critique of Judgment. In its study of actual natural science it is only "formally teleological" ; and besides, Cossmann understands just as little as Wolff, and as I myself in my first writings, the difference between static and dynamic teleology.

Causality, he considers, has universal but not exclusive validity, and he places teleology beside it as a maxim of judgment. It deals with necessary associations, for the idea of necessity is ever larger than that of causality. The general formula: $\mathrm{C}$ (Cause) $=\mathrm{f}(\mathrm{E})$ (Effect), suffices for the causal theory, the words "cause" and " effect" being used in a very general sense as summarising the totality of everything which comes into consideration. Teleology is expressed by the formula $M=f(A, S)$, in which M indicates Medium, and A, S, Antecedent and Consequent.

The functional sign indicates in both cases logical dependence or logical affinity of meaning.

Even if Cossmann does not solve the problem "Vitalism or Mechanism ?" he at least determines in a positive sense the validity of a profoundly 
significant vital teleology not explicable by mere chance. A very large part of his book is devoted to this purpose.

Eugen Albrecht, in his Vorfragen der Biologie (1899), maintains that physics and physiology are but different points of view relating to the same reality. This seems to agree with the results of Cossmann's researches; it does not go beyond my own statements in the Analytische Theorie (1894).

Johannes Reinke has since 1899 devoted himself with great energy to the teleological problem, and has published a succession of books and articles ${ }^{1}$ on the subject. His treatment is rather abstract and does not refer much to facts. He asserts that all specific movement is the result not only of energy, but also of those forces which Lotze called "second-hand." Reinke describes these forces by the general term "Dominants." By this term he evidently means not only the laws of mechanism, but also the so-called "constants."

Latterly, Reinke has called these doubtful powers "system-forces," when considering the facts of physiology proper, and he is convinced of their mechanical nature. In this he is a static teleologist. He now reserves the name "Dominants" for the physiology of form and leaves their character doubtful, so that in this field, he is at most a problematic Vitalist; at times here too he even seems to incline to the mechanical theory. He certainly

1 Die Welt als Tat, Berlin, 1899 ; "Gedanken über das Wesen der Organisation," Biol. Zentralblatt, 19, 1899 ; Einleitung in die theoretische Biologie, Berlin, 1901, etc. Reinke himself considers his article "Die Dominantenlehre" (Natur und Schule, 2,1902 ) as his best production. 
expressly rejects the theory of parallelism for the psycho-physical, and in this respect must be considered a real Vitalist.

This acutely elaborated theory of "Dominants," and the concentration of his researches on the problem of their nature, is Reinke's most valuable achievement. He does not refer, however, to my arguments on the autonomy of vital movement.

It should be mentioned that Fritz Noll prepared the way for a line of enquiry ${ }^{1}$ which we consider as full of significance for Vitalism. But as it principally concerns the analysis of particular facts, it cannot be analysed here in detail.

Pauly ${ }^{2}$ has lately been supporting a theory of life with a psychological basis. His vital principle works like a man who makes experience. I do not think that any such formula can fully express the dynamic-teleological phenomena of vegetative life. The views of Jennings, Holmes and S. Becher, and perhaps also Child are more or less similar to those of Pauly. Schneider's ${ }^{3}$ Vitalism is more valuable for the conceptual and ontological sections than the doctrine which he expands. Semon's "Mneme" " is not vitalistic but expressly conceived in a mechanical sense. For him the word "memory" is only a short way of summing up a complex of mechanical factors not yet fully analysed.

The remainder of the vitalistic utterances of the

1 Landwirtsch. Jahrbiicher, 1900 ; Biolog. Zentralblatt, 25, 1903.

'Darwinismus und Lamarckismus, Munich, 1905.

${ }^{3}$ Cf. his article on "Vitalism" in Zeitschrift für den Ausbau der Entwickelungslehre, vol. i. 1907.

4 Leipzig, 1904, second edition, 1910. 
immediate past do not throw any essential new light on the subject, but confirm, more or less, in a slightly altered form, the conclusions which we had already reached. If we wished this work to be quite complete, we should hare to touch upon the publications of Auerbach, Bechterew, Bell, Dreyer, Fischel, Francé, Gemelli, Haldane, Hartog, Herbst, 0. Hertwig, Japp, Lodge, Mackenzie, Morgan, Moskowski, Neumeister, Ostwald, ${ }^{1}$ Schmitz-Dumont, Strecker and a few others; and we should also hare to examine the antagonistic arguments of Bütschli, Detto, Klebs, Julius Schultz and others. Even more important are the works of Gurvitsch on Determination, and his reflexions on heredity, 2 while Bergson's fundamental theories should be studied in his own well-known writings, and especially in Crentive Evolution.

If anyone should wish to obtain further information, he might read the articles ${ }^{3}$ in which I defined my own position in relation to supporters and opponents of $\mathrm{my}$ doctrines of autonomr; and he may also be referred to E. ron Hartmann's essay on "Mechanism and Vitalism in Modern Biology;" "

${ }^{1}$ Ostwald's "geistige Energie" appears to me far too problematical and not sufficiently analysed, to be brought forward in my text as a real advancement of Vitalism. For further iniormstion, cf. the essays mentioned in a later note. We shall, moreover, consider the relations of Vitalism and energy in the systematic section.

'Biol. Cenirablalatt, 32.

"Biol. Centralblatt, 22, 1902; 23, 1903. Jensen's latest objections to Vitalism are very weak and by no means new.

"Arch. f. ayst. Philas., 9, 1903. The essay by W. Bieganski: "Neo-Vitalismus in der modernen Biologie" (Annal. Naturphil., 4, 1904, p. 47) may also be recommended, though with reservations. 
and to the final work of this great thinker, Das Problem des Lebens (1906).

History must cease when the battles of the present begin.

And now, as one of the combatants, I propose to trace, without reference to history, the systematic development of the views which I myself consider as correct in the fundamental questions of biology. 

PART II.

THEORETICAL. 



\section{FOREWORD.}

IN the original German edition of this work (1905) the historical portion is followed by a short Zweiter Hauptteil, entitled Der Vitalismus als Lehre, in which a condensed account is given of what $I$ call the proofs and indicia of the autonomy of life and of the relation of "entelechy" to the two principles of energetics as well as to the concept of substance. As all these topics are dealt with in my Gifford Lectures (1908) in a much broader, and, as I hope, better manner, and as a sort of summary of the Gifford Lectures is given in the first half of The Problem of Individuality (1914), containing a course of lectures delivered before the University of London, it seemed best to leave out the Zweiter Hauptteil in its original form, and to put something new in its place.

The original Zweiter Hauptteil as well as the Gifford Lectures and the new little book just mentioned, proceeds in what might be called the ascending or inductive way. They all begin with facts, analyse them, form theoretical concepts on the foundation of the analysis, compare these concepts with those which have been created in the sciences of the inorganic world, and-at least in the Gifford 
Lectures and the new book-finally try to formulate the real logic of Vitalism and to sketch the problem of " universal teleology." But it appears to me that the reverse of all this might be of interest for the reader; a system of Vitalism namely that does not ascend from the facts to a theory, but descends from a theory, i.e. a logic of possibilities, to the fact, i.e. to realities.

In my Ordnungslehre, ein System des nicht metaphysischen Teiles der Philosophie mit besonderer Berïcksichtigung der Lehre vom Werden (1912), this method is already adopted, but with purely logical, or better, categorical, aims ; in what is to follow I shall try to develop what might be called "deductive Vitalism," with special reference to the claims of theoretical biology. Thus, deductive Vitalism as a real union of logic and biology, or rather as a sort of filling out of certain departments of logic with biological facts, will be developed here for the first time.

HANS DRIESCH.

Heidelberg, March, 1914. 


\section{$A$. PURE LOGIC.}

Pure logic, as the general theory of order, deals with everything that is in the most general sense of being. Being here means nothing but being had by myself consciously in the form of a this. We shall apply the word object-(Meinong's "Gegenstand ") -in this most general sense. Everything then that may be "consciously had," is object-a sensation or a feeling or a reproduction of a sensation or a thought of whatever kind: and the totality of objects in this sense is to be ordered.

Pure Logic starts with the irreducible concepts of order: this, such, and relation. Among relations are identity, difference ("otherness") and consequence (i.e. a position is because there is another position).

Whatever is an object is such, and its suchness must be defined. Now definition not'only analyses the object, but, strange to say, also destroys it. For the object is not the mere sum of its attributes : it is their unity-it is all the attributes together.

Thus, the concept of wholeness is already found in pure logic. 


\section{$B$. NATURE.}

The objects of pure logic as the general theory of order may be called immediate objects; they are, in fact, the immediate contents of consciousness.

Now there are some immediate objects which mean or signify mediate objects or, as we generally say, objects of nature. The objects of nature "are" as if they had an independent being for themselves. "This dog," for instance, is a mediate object or an object of nature ; that is to say, whenever I think "this dog" in any form whatever, I mean by my thought, as an immediate object, a certain mediate or natural object in its quasi-independent singleness. In a similar way all so-called objects of nature are "meant."

But when does an immediate object (a thought or a sense-image, etc.) mean or signify an object of nature, and when does it not? For practical purposes I almost always know when I have to refer an immediate object, a "givenness" so to say, to this strange quasi-independent realm which I call nature, but logic demands a better criterion and is not satisfied by the mere statement that "dreams," "real sensations," and "memory-images" are distinguished one from another quasi-instinctively.

In order to discover the criterion which we are seeking we must first consider a very strange feature of conscious life. 


\section{BECOMING.1}

At one moment I "have" this consciously, at another $I$ have that, and then again $I$ have something else, and so on. This is the so-called stream of consciousness. But there is nothing like a stream quite immediately given to me: on the contrary, my having consciously is always a "now," or better still, it is entirely unrelated to time. I have this immediate object, this content, now-that is all. But among the contents which I have consciously there can be distinguished a very peculiar class of what may be called signs; and these signs, which are had in a now, mean "not now but then (i.e. earlier)", and they may even mean " earlier than."

Thus it is as if I were always identical in one respect, and yet at the same time not always identical in another. I am always identical as one who is a consciously having person in general, but I am not always identical as one who has special contents. This I formulate as follows: as having

1 B. Russell (Princ. of Math., i., Part vii., in particular p. 471; cf. my Ordnungslehre, p 174, note 1 ) and his followers believe they can do without such concepts as becoming and change. This may be true for mere " motion" of a physical point, though even here the introduction of a particular function in the place of motion as a something sui genesis does not afford a real understanding. But such a mathematical reduction of becoming (if I may say so) is quite impossible in the realms of biology, history, etc. (cf. Ordnungslehre, p. 210, note); and it neglects the truly original meaning of becoming, i.e. its meaning with respect to the ego. 
consciously in general I am enduring: as having special contents I am becoming.

Here we meet for the first time the curious concept of becoming; and this is at the rery root of "categories" substance and causality, as will be shown at a later stage.

The next step is this: I look from my haring at what I have; this, i.e. the totality of immediate objects I call It, and then I say It becomes. In this way a certain connexion between the different contents of my consciousness at different "nows" is established. But not very much would be gained in this way if, firstly, the enduring part of the It. could not be shown, and if, secondly, something more could not be said with regard to becoming.

In the concept of enduring in general. identity has, so to speak, been thrown outwards; enduring is identity, but it means something that is alwars the same in time, not merely as a concept : it is identity petrified. But suppose the concept of consequence could also be made more than a concept of pure logic and could also be "thrown outwards " upon the It. What, if becoming could be formulated as if an earlier phase of it were always the reason of a later phase, and a later phase the consequence of an earlier one? If this were possible then we might claim to understand becoming, to have rationalised it.

Now it is certainly quite impossible to fulfil the logical demands mentioned here with regard to the becoming of immediate objects as they are given to me. Think of what you "hare" consciously during a period of. say. fire minutes: there is an enormous rariet! of contents of immediate objects, 
but there is neither any clearly enduring It, nor any sort of quasi-rational connexion in becoming itself.

Must we therefore deny the possibility of a logical theory of becoming? By no means.

It is quite true that the totality of what I consciously "have" as immediate objects cannot be forced into the scheme of the theory of becoming with its postulates of something that endures and of rational connexion. But there is a certain something which I mean by part of that which I have as mediate : and this something, as we know, is called nature or natural reality, and nature fully obeys the postulates of the theory of becoming. In nature we may successfully search for something that endures, and in nature we may regard becoming as if any phase of it were the "reason" of a later phase and the "consequence" of an earlier one. We may even go so far as to say: Nature is the one mediate object that obeys the postulates of the rational theory of becoming. In other words: whether any immediate object that I consciously have (an optical or other image, a thought, etc.) is to be related to a mediate object in nature or notis decided according to the harmony or disharmony of becoming in which this mediate object would stand to those mediate natural objects which have already been theoretically established. By this argument and by this argument alone is "natural reality " distinguished from the world of dreams and from the world of imagination.

Nature, then, is the proper field of a theory of becoming. What endures in nature may be called substance, the rational connexion among the changes 
in nature may be called causality. Both concepts, substance as well as causality, have been formed by a special sort of transformation of meaning out of the purely logical concepts identity and consequence -(this and because). Thus pure logic, the pure "theory of order" remains always the real foundation of all philosophy of nature : or, in other words, the " categories" rest upon purely logical concepts. 


\section{THE FORMS OF BECOMING.}

The concept of becoming, then, rests upon certain signifying contents which are immediately " had": the concepts of substance and causality, on the other hand, are founded upon certain logical concepts applied to becoming in the manner of postulates : the concept of nature in its exact sense rests upon all these.

The question now arises whether we are not in a position to say something more about natural becoming a priori, i.e. starting merely from what the concepts of becoming, substance, causality, and nature mean. And we are indeed able to do so-at any rate if we consider a certain feature always connected with our having an immediate object that "means" something in nature. We may describe this feature as of an empirical character taken for itself-just as the "sign" that means then or before is of an empirical character-but even then the following reasoning may be called a priori since it only deals with possibilities, and does not go into any details of real experience.

The special feature common to all our immediate data that are related to nature is this : they all have the sign of spatiality, they all mean not only a now 
but also a here. In fact, what we call our "knowledge" of 'nature rests ultimately and exclusively upon data of the form now-here-such.

All our knowledge about nature out of which we form our experience about nature as a something that is becoming or changing, must therefore also rest ultimately upon data of the form now-here-such, and upon nothing else. The importance of this is obvious, for it means that all immediate experience of nature is spatial experience-and this applies, of course, with regard to change or becoming as well.

That is to say: Whatever the theory of natural becoming may ultimately lead to, it always has to start from "a becoming in space," i.e. from two spatial states between which we may say that there is becoming. This " becoming" is to be rationalised. It is to be regarded as if it were the consequence of any "other" becoming earlier in time. That is all that the rational theory of becoming postulates. It does not postulate that the "other," earlier, becoming, which is to be the cause of the immediately given becoming, shall be also becoming in space, or, in short, spatial becoming. It may indeed be so, but that is not necessary: and this point, too, is of very great importance.

But before we can realise its importance we must return once more to the fundamentals of our rational theory of becoming, i.e. to pure logic as the theory of order in general.

Whenever there is something-in the sense of being an object, a "position" 1 -becaluse there is something else, that which formis the reason must í Sé page 189. 
alwaỳs be richer in content, i.e. richer in attributes than the other which is its consequence. We may speak of the-degree of manifoldness of - a concept, meaning thereby the number of different irreducible, (elementary) characters which enter into its complete definition-these characters bèing suchnesses and relations. The reason, then, is always of a higher degree of "manifoldness than the consequence. The being of the concept " dog" is the' reason of the being of the concept "animal ": "justice" is the reason of "virtue" : " engine" of " manufactured object," etc. ${ }^{1}$ Now in our theory of becoming one becoming is to be regarded as if it were the consequence of an earlier one. The one becoming we start from is, as we know, bordered by two spatial states: each of these states may be signified by a concept giving account of the different irreducible "things" of the state, and of the relations between the things. We may say, shortly, that each of the two states which border on one immediately experienced becoming has itself its proper degree of manifoldness. What, then, we must postulate, if our theory of becoming is really to provide us with an analogy to the logical relation of consequence, is the following: The degree of manifoldness of a natural system can never increase of itself, i.e. without a cause as its quasi-sufficient reason. To allow this would be to abandon the rational theory of becoming.

1 We take the concept of reason in its most fundamental sense, and relate it to concepts not to proper " judgments" (see my Oranungslehre, pp. 53-66): With regard to the peculiarities of arithmetical and geometrical concepts see Ordnungslehre, pp. 58, $120 \mathrm{f.,} 140 \mathrm{f}$.; but this topic, thought very important for the problem of Systematics, may be left out of account here. 
This, then, is the foundation of all further reasoning about causality - taken together with the fact that one spatial becoming always forms the immediate datum of all reflexion: whenever there is an increase of the degree of manifoldness in the one spatial becoming that is to be rationalised, there must be a quasi-reason, i.e. a cause, for this increase that is outside the system itself.

And now we are in a position to develop the a priori theory of the different types or forms of becoming.

First type: Given a natural system that shows different stages at the times $t_{2}$ and $t_{3}$ between which there was becoming transforming state $B$ into state $C$. If now $B$ and $C$, though different in their particular features, are of the same degree of manifoldness ; and if a third state $A$ of the system earlier than $B$ may be discovered which is also of the same degree of manifoldness; then every singularity of becoming between the states $B$ and $C$ may be causally related to a singularity of becoming between $A$ and $B$. The problem of rationalising the becoming between the times $t_{2}$ and $t_{3}$ has been solved.

This problem can also be regarded as solved if, though the state $A$ in the system itself is wanting, so that there is a real increase of manifoldness with regard to the system as such, yet there is spatial becoming "outside" the system (in the spatial sense of the word): and from this the increase of the system may be understood. In this case also every singularity of the immediately experienced becoming may be connected with a singularity of earlier spatial becoming.

We propose to call this type of becoming or rather 
this type of causality, singular or additive causality. The manifoldness of the system is here a mere sum : its different parts are changed in themselves, irrespective of the others. This is the type of becoming that is illustrated by the sciences of the inorganic world. At present at any rate all so-called inorganic processes may be understood according to this scheme. And general principles-those of mechanics and energetics-have been formulated to give special expression to the various important aspects of rational becoming in the case of singular causality.

Second and third types: These types of becoming are of great importance for the general theory of natural order, being the expression of certain a priori possibilities. But they are not realised in nature as far as we know, and need, therefore, only be mentioned shortly here.

In view of what becoming means and of the fact that immediately experienced becoming is always spatial becoming, it is quite conceivable that between the times $t_{2}$ and $t_{3}$ the number of elementary material constituents ("atoms") of a system might increase without there having been a passage of atoms into the system from "outside" in the spatial sense. In order, then, to save the principle of rationality in becoming, thing-creating agents must be accepted which have " made" these atoms.

And it is further conceivable that a system, hitherto changeless, may begin to change at the moment $t$ without there being a moving cause anywhere in space. Change-creating agents must have been at work in such a case.

As has been said, nature seems not to have 
realised these two possible types of becoming. Certain psychologists who do not accept the theory of "psycho-physical parallelism," have, it is true, burdened the "soul" with the creation of material energy, but the relation between "body" and "soul" can, we think, also be conceived on the basis of our fourth type of becoming.

Fourth type: Let there be a system of a given number of things and a given number of different relations among the things. Then between the moments $t_{2}$ and $t_{3}$ there may be becoming which changes the state of the system in such a way that the number of different kinds of relations among the things increases without there being any kind of spatial agency that can be made responsible for this increase. In this case "immaterial" or nonspatial agents must have been at work if the rationality of becoming is to be saved at all. These agents need not have been of the "creating" sort-it is assumed that we know they are not. In other words, there has been a sufficient reason in space for "becoming" in general, i.e. there has been a supply of spatial energy for what has happened; but it is with regard to the peculiarities of becoming that there is a lack of sufficient reason in spatial change. There must have 'been non-spatial agents, of a controlling type, so to speak.

The most important form of this type of becoming would be that in which a distribution of the things in one system of the form of a mere sum would be transformed into a distribution that would be in some sense a unity or totality, without any spatial mechanical predetermination of this totality. 
To put it very simply but clearly : an arrangement of things (atoms) of this form :

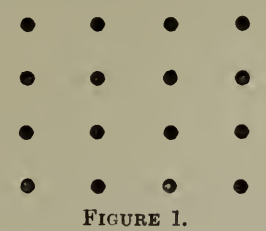

i.e. an arrangement that may be defined by very few terms, because it is of a very low degree of manifoldness, may be transformed into an arrangement such as this :

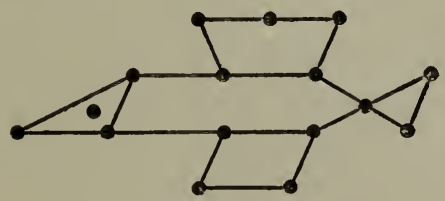

Figure 2.

without spatial preformation. There are sixteen "things " in each case, but the first arrangements of these things is clearly a sum, whereas the second resembles in form-a " fish."

We shall call this type of becoming unifying or individualising causality.

If a system passes through several phases of becoming in succession, all controlled by unifying causality, we may speak of the evolution of the system: and every singularity of becoming that leads to the unity as the final end may be called purposive or teleological. But the concepts of unity and of unifying causality are the more fundamental.,

It will be shown that unifying causality is the prototype of biological, i.e. vitalistic becoming. 


\section{E. INDIVIDUALISING AND SINGULAR CAUSALITY.}

We now enter the realm of Vitalism proper, i.e. the theory of the autonomy of the processes of life. And first of all we must study a little more intimately the manner in which individualising causality (established above as a logical possibility) may act in the material universe, or rather with regard to a given finite material system.

There is no creation either of matter or of the prerequisites of change as such if pure individualising causality is at work: there is only regulative or controlling action in addition to energetical becoming -as a special aspect of singular causality. What does this mean?

It means, firstly, that the so-called first principle of "Energetics" - the principle of the conservation of energy-is not violated by our individualising agent. This is postulated by the theory, andwe may say this already here-the experiments of Rubner, Atwater and others have shown that it holds empirically. The principle of the conservation of energy holds good for the organism.

But what about the second principle of Energetics, the "principle of becoming " (Satz des Geschehens) 
in the terminology of Helm and Ostwald? This principle, which, like the first, is fundamentally a priori, states that all becoming is space depends on the existence of differences of what is called the "intensity" of energy, as, e.g. temperature. May this principle be saved also in spite of the action of individualising causality? I think it may, if only we suppose that the non-mechanical agent which is the bearer of individualising causality is able to suspend such happening as is possible on the basis of pre-existing differences of intensity and as would occur without the suspension. Suspending possible change and relaxing suspension would then be the two modes of "action" of the bearer of individualising causality which we shall henceforth speak of as entelechy. The name, though well known in the metaphysical terminology of Aristotle, is not here used in the proper Aristotelian sense. ${ }^{1}$

If in our figure 1 (p. 201) the points stand for sixteen systems equal one to another and each endowed with endless "possibilities" (in the form of given differences of energetic intensities), we can understand how this homogeneous distribution of possibilities may be transformed into a heterogeneous distribution of realities, figure 2 . In order that this may happen it is only necessary that entelechy, which is supposed to have suspended all possibilities so far, relaxes its suspension for each system in a different way.

By our theory, that the action of entelechy consists in the suspension of given possibilities, we avoid a very serious fault of almost all forms of 
ancient Vitalism (and of many forms of modern Vitalism too). It has often been urged against Vitalism that according to its doctrines the organism should be omnipotent, whereas in fact, there are limits to all regeneration, adaptation, etc. On the basis of our theory, these "limits of regulability," to express ourselves briefly, may readily be understood : it is on given, preformed, material conditions that the action of entelechy depends.

It may be well to explain here in detail that entelechy - or any other individualising agent, if such there be-is itself neither "an energy" nor " a material substance" of any special kind : such an assumption would lead to absurdities. ${ }^{1}$ Entelechy is an agent sui generis, non-material and non-spatial, but acting "into" space, so to speak; an agent, however, that belongs to nature in the purely logical sense in which we use this word.

Another theory with regard to the possible relations among material and non-material agents of reality was developed by Descartes and later by Eduard von Hartmann, the last great metaphysician before Bergson. Both authors defend the view that the non-mechanical agent-the "soul "-may alter the direction of material particles, and by this action also alter the directions of all forces which go out from them. It is clear that this hypothesis starts from a purely mechanical, as opposed to the more energetical point of view. The theory is possible: and the principle of the conservation of energy in its most general form $-(\Sigma(\mathrm{E})=$ Const. $)$, though not for the three axes of space separately-would also be

${ }^{1}$ See Gifford Lectures, ii. pp. 167 ff., 249 ff. 
preserved. But the fact that there are "limits of regulability" would not be well accounted for by such an assumption. My own hypothesis, on the purely mechanical ground, is therefore as follows : Wherever individualising causality is at work we have systems embracing potential and kinetic mechanical energy; both kinds of mechanical energy are "in suspension"; with regard to both suspension may cease. Thus everything turns out as in the energetic formulation. ${ }^{1}$

A few general remarks may conclude this section.

If we say that entelechy, whenever it ceases to suspend preformed material becoming, allows a "possible" happening to become "real," we do not mean to imply that any obstacle to becoming, in the mechanical sense, is removed by entelechy; for such a removal in the mechanical sense, such an Auslösung, would require energy, and entelechy is per definitionem non-energetic. Entelechy only allows that to become real which it has itself held in a state of mere possibility-not what has been in this state simply as a result of physico-chemical influences.

It is useless to speak about the origin of entelechial suspension in nature; useless, i.e. to discuss the origin of life. It is absolutely impossible for us to say anything definite on this subject. Similarly it is useless to discuss the meaning of death. At the end of this book a few words will be said about the individuality or totality of the universe in general(about what is also called the problem of " universal teleology"), and these problems will then be briefly

${ }^{1}$ See Gifford Lectures, ii. pp. 218-225 
mentioned, but there, too, only in a formal and logical sense.

The foregoing has been written with reference to a special problem of actual science, i.e. the problem of the individual biological organism; but it must be borne in mind that it holds good for any kind of unifying or individualising causality, and that it was only for the purposes of the present exposition that it was based on the specific concept of entelechy. 


\section{F. THE EMPIRICAL PROOFS OF VITALISM.}

What we have tried to show so far is this: There is the irreducible concept of a whole with its parts; there is the possibility of different forms of becoming, for there are more possible forms of causality than only spatial or singular, i.e. physico-chemical or mechanical causality; it is possible to formulate an idea about the relations between mechanical and non-mechanical causality (the theory of the "suspending " action of entelechy).

We now proceed by showing that non-mechanical causality exists in nature, at least in a certain limited field. This is a purely empirical problem. It might have turned out that the concept of unifying causality was a mere concept of logic, having no representative in nature as we have defined it. This would be the case, if it were possible to conceive all natural becoming mechanically. The concept of wholeness or individuality might hold for nature or parts of nature in this case also, in so far as there were mediate objects in nature which were indubitably unities. But in the case of the possibility of a mechanical conception of nature, no becoming by which spatial wholeness is formed out of spatial non-wholeness would exist; all wholeness would 
prove to be spatially preformed, just as wholeness is preformed in a machine. A theory which applied to nature the concept of wholeness but not the concept of unifying causality might, indeed, properly be called the machine-theory of nature, or, if life alone were considered, of life. The machine-theory would already be opposed to the conception of nature (or life) as a mere field of chance.

Vitalism now tries to show that life is not only not a mere field of chance, but that its phenomena are not even covered by a machine-theory.

All proofs of Vitalism, i.e. all reasonings by which it is shown that not even the machine-theory covers the field of biological phenomena, can only be indirect proofs : they can only make it clear that mechanical or singular causality is not sufficient for an explanation of what happens. Indirect proofs of this sort may be given on three different and independent lines.

The first line of argument is this :

Analytic experimental embryology-Entwicklungsmechanik, as Roux has called it-has been able to show that there are many kinds of embryonic organs or even animals which, if by an operation deprived of part of their cells, behave in the following way : of whatever material you deprive these organs or animals, the remainder, unless it is very small, will always develop in the normal manner, though, so to speak, in miniature. That is to say: there will develop out of the part of the embryonic organ or animal left by the operation, as might be expected, not a part of the organisation but the whole, only on a smaller scale. I have proposed the name of 
harmonious-equipotential systems for organs or animals of this type ; they are "equipotential," because all their elements (cells) quite evidently must possess the same morphogenetic "potency," otherwise the experimental result would be impossible; and their elements work "harmoniously" together in each single experimental case. It is only on the basis of their equipotentiality and of their harmonious working that the experimental results can be what they are.

Among embryonic organs the cleavage stages and the so-called germ-layers, for instance, are harmonious-equipotential systems: take from the blastula of a sea-urchin whatever you like (but not more than three-quarters) and the rest will always develop into a very small but complete "Pluteus."

Whole adult animals prove to be of the harmoniousequipotential type in many cases of restitution (regeneration), i.e. when they restore their form after violations. The branchial apparatus of the Ascidian Clavellina, for instance, is able to give rise to a complete little organism by a mere rearrangement of its material without the formation of new cells, and so in any part of this apparatus, cut it how you will.

So much for the facts, which are very various and numerous.

If now we turn to the theoretical analysis of the facts, it might seem at the first glance as if no further discussion were required: whenever an organism or part of an organism, adult or embryonic, is an harmonious-equipotential system, a homogeneous distribution of possibilities (i.e. cells which all have 
the same morphogenetic potencies) is transformed into a heterogeneous distribution of realities (i.e. s specific parts of cells with specific physiological functions), and this is clearly the very scheme of what we have called unifying or individualising causality. Unifying, i.e. non-mechanical, causality then seems to be at work whenever a harmoniousequipotential system develops itself.

But the problem is a little more difficult than it seems at first, though, it is true, our short reasoning meets the main point.

Might there not be some sort of machine inside the harmonious system, on the basis of which all its evolutionary acts occur? Weismann did regard embryology in this way, and his theory was legitimate so long as there were no experiments. Experiments now show that any part of the system, however large and wherever taken, may be cut away from it without disturbing proportionate development. This, proves that a "machine" cannot be the basis of harmonious-equipotential differentiation : for a "machine," i.e. a specific arrangement of physico-chemical things and agents, does not remain itself, if you take from it whatever you please, and the organism, or, better, the non-developed harmonious system does remain "itself," with regard to its morphogenetic faculties, after any operation whatever.

The harmonious system, then, is not a " machine"; it is, in fact, as it seemed to be from the beginning, a something that is governed by Individualising Causality. " Entelechy," as a non-mechanical agent of nature, is at work in the harmonious-equipotential system. 


\section{THE EMPIRICAL PROOFS}

No other argument in favour of Vitalism meets so well the purely logical requirements of the theory of becoming as does the one that is based upon harmonious differentiation. But there are still two others, which as proofs of Vitalism, or, better, as disproofs of the machine theory of life, are of equal rank.

The first of them, which is at the same time the "second" independent proof of Vitalism, runs as follows :

There is another kind of equipotential system than the harmonious-equipotential ; and the ovary is an instance of such a second type. The ovary is a complex-equipotential system. Whilst in the harmonious-equipotential system the whole is formed by the harmonious co-operation of all the single elements, in the complex-equipotential system each element for itself is capable of forming the totality ; equipotentiality consists here in the fact, that all elements are "equally" capable of so operating.

Now all this proves nothing for or against Vitalism when taken for itself; but it is different if we consider the genesis of an equipotential system of the complex type. The ovary, for instance, has come from one single cell in the course of embryology, i.e. from its "Anlage," to use the untranslatable German term which biology is adopting. This Anlage-cell has been divided and re-divided innumerable times; the last products of this long process of divisions are the eggs. 'We now simply say : How could a machine (differentially built up in the three dimensions of space as an embryological machine in any case should be)-how could a machine be divided innumer- 
able times and yet remain what it was? No machine, therefore, can be the test of embryology.

It appears, in short, that by this argument socalled inheritance is shown not to depend on mechanical factors exclusively; material conditions, as studied by Mendelism and in the experiments of Boveri and Herbst, are only means of inheritance, but are not its proper essential factor.

Whilst the second argument in favour of a nonmechanical interpretation of life has a certain resemblance with the first one, the third proof of the autonomy of life, which we must now try to sketch shortly, follows a direction of its own.

What occurs in nature when a man acts? What does acting mean considered as a natural phenomenon apart from all introspective psychology ? To what general laws is the body of an acting man, considered as a natural body, subject?

Analysis shows that action of any kind whatever does always bear these two essential features or criteria. Firstly, it rests upon a basis of possibilities which has been created historically, i.e. in the course of the individual life of the acting person; or shortly: it rests upon an historical basis of reaction. That is to say, every action is determined-though not exclusively-by everything that has occurred to the acting person until this very moment of his life. Had we not decided to put aside all psychology in our argument, we might say that "experience", based upon "memory" is one of the chief features of all acting.

"But-does not also the phonograph "act" upon an historical basis of reaction? Certainly it does, 
and it is especially in order to distinguish the acting organism from machines of the type of the phonograph that a second criterion of acting must be added to the first. The phonograph only gives off what it has received, in its very specificity ; in the organism the occurrences of individual life have only created a general stock of possibilities for further acting, but have not determined all further reactions quite in detail. What really happens in any case of acting -always upon the historical basis in general-occurs according to a curious principle, which may be called the criterion of individual correspondence. That is to say : any real action is an individual "answer" to an individual stimulus-founded upon the historical basis.

And this individual correspondence, occurring upon an historically created basis, cannot be understood as a case of mechanical causality. For there is not a "sum" on the side of the stimulus that corresponds to a "sum " on the side of the reaction, and, further, not even the possibilities of acting are in any way " performed."

From this point of view, the brain and the nervous system appear as nothing but as necessary means for putting the "acting" factor into connexion with material nature; but they are not themselves the acting factor.

These, then, are sketches of the three proofs of Vitalism. Further proofs may be possible, and it is to be hoped that others may be able to find them; but one proof, of course, is sufficient, if it is a real "proof."

Besides what I regard as arguments proving the 
impossibility of a mechanical conception of life, there are several arguments which, though not proofs in the strict sense, may be called indicia of the autonomy of life. These indicia of Vitalism can only be shortly mentioned here, interesting as they are; in my Gifford Lectures a full and thorough account of them may be found.

There are, firstly, the various facts regarding complications in processes of restitution i.e. restitution of the second order or the "restitution of a restitution," and the phenomenon of "equifinality" ; or the fact that the same regulatory result may be reached on different morphogenetic lines. Then there are the innumerable facts of active adaptation-not of adaptedness as a mere stateon the grounds of morphology as well as of physiology, and among animals as well as among plants. The formation of what the theory of immunity calls "antibodies" is the most remarkable case of them. And, finally, there are the phenomena of instinct and its regulations, which, unfortunately, are not even as mere facts sufficiently analysed at the present day.

All these facts are either reducible to those underlying the first of our proofs of Vitalism, or they show that the organism is of the type of an individual unity in nature; but they do not prove unifying becoming. For to be of the type of a natural unity is not the same as for a thing to owe its origin to unifying becoming immediately, and it is with unifying becoming alone that Vitalism has to do. In the introduction to this book the difference between "static" and "dynamic" teleology has 
been urged. We have avoided in this sketch the concept of teleology almost completely, having put the concept of unity or individuality in its place and having spoken of unifying instead of teleological becoming. But it is clear without further discussion that, if we were to apply the teleological concepts, we might say that all " indicia" of Vitalism do not prove "dynamic" teleology, i.e. Vitalism, but only prove teleology in general, leaving the specification open, or " static," i.e. machine-like or preformed, teleology. Therefore all these " indicia," and among them even the strange facts of the formation of antibodies, are more important in as far as they state problems for future analytical research, than as solutions of any question.

To sum up : the organism, as studied by the science of biology, affords an instance of unifying or individualising causality, i.e. of one of the elementary forms of causality, in so far as its morphogenetic or moving behaviour is concerned. Whenever there appears an harmonious-equipotential system in the course of its morphogenetic behaviour, the organism may even be said to be a quasi-verbal illustration of what unifying causality, as one of the types of possible non-mechanical forms of causality, means : a sum (of possibilities of happening) is transformed into a unity (of real results of happening) without any spatial or material preformation of this unity. 


\section{G. THE PROBLEM OF SUPRAPERSONAL INDIVIDUALITY.}

Vitalism, so far, has been considered as a purely biological theory. Individual biological becoming is in fact an illustration of one of the elementary forms of becoming that are possibly a priori; the words " in fact" are the main thing in this phrase ; it is by them that a progress from mere logic into the field of the philosophy of nature is made.

Now the problem that first of all arises is this : Are there other "systems" in natural reality, besides those which we call individual organisms, for which we are able to prove, or at least to suppose, that becoming with respect to them is also in fact an illustration of the one possible type of causality that we have called unifying or individualising causality? And this is an empirical problem, just as was the problem of Vitalism proper.

It may as well be plainly stated at the outset that we do not know in any case, whether there be any further factual illustration of unifying cause, but we may suppose that there is some such illustration in various fields of reality.

If we start from pure logic we might at the first glance suppose that there are very many cases, if 
not of unifying causality, at least of factual unity. Is not every concept a unity? And might we not say, therefore, that, wherever we have any concept that "means" as its mediate object an object of nature, we also have conceived this object of nature as a unity ?

Our problem is, however, more complicated ; for logical or conceptual unity does not warrant real unity in the least way. We may take out of reality anything, any "system" we want, and "mean" this by one single term. The term as a logical formation is then always a "unity," but it would cause nothing ; nay, it would disturb the concept of real unity to say that the "system" as a natural object is a unity also. To say so without a very detailed consideration would deprive the concept of real unity of that undoubted significance which it may have if considered and applied carefully.

"River," "island," " mountain," "the state," " the organism," "England," " humanity," "a street," "a lion" are certainly all unities as concepts, meaning certain natural (mediate) objects or classes of natural objects. But, as to real unity, we knou so far only that " the organism " and "a lion " are unities, built up by unifying becoming. With regard to all the other objects a special investigation is required.

What sort of an investigation is this to be ?

It would no doubt be best could we study in an analytical way the "becoming" that has led to the natural objects mentioned, as we have studied analytically the becoming that has formed the individual organism. And, in fact, this is possible with respect to some of these objects. With respect 
to " river," " island," "mountain," "a street," we may say in fact, on the basis of our knowledge of what call geological and psychological becoming, that the concepts of river, island, mountain, a street, though unities as concepts, do not mean objects which are unities. For the geological becoming that has led to the presence of rivers, islands, and mountains, and the psychological or psycho-physical becoming that has led to the presence of streets seem clearly to be of the type of singular causality. In short: as objects all these systems are sums and nothing else. Certainly, they all owe their existence to processes of complication ; but these complications are cumulations and not evolutions-if by "evolution" we mean a complication from within, based upon unifying becoming, and by "cumulation" a complication from without, based upon the mere circumstance that one phase of singular becoming is superimposed, so to say, upon the other. And the latter is true for rivers, islands, mountains and streets-so at least we are allowed to say without quite a new kind of consideration not mentioned as yet; so at least we may say on the basis of what is commonly called "science."

But with regard to the objects signified by the words "the state," "England," " humanity," we know nothing as to their being the result of an evolution or a cumulation. Can we know anything, in this case, in the same way as we have a knowledge of the evolutionary character of the processes that lead to the individual organism?

Phylogeny, and history as the continuation of phylogeny, are the two great fields of reality we have 
now to study; the first of them is far more problematic than the second, for with regard to so-called phylogeny we do not even know, in the absolute sense of the word, whether it has occurred at all, though we may regard it as highly probable. Are, then, phylogeny and history evolutions? Is the present state of mankind the result of any kind of unifying causality? Or, to put the question in the language of this book, are the various single processes of phylogeny and history dynamic-teleological processes, if we call "dynamic-teleological" any singularity in the midst of a totality of processes controlled by individualising causality?

Let us be brief about phylogeny. We may, it is true, accept the theory of descent; but Darwinism and Lamarckism do not touch the main point of the problems; they apply only to parts of it which are of secondary importance. We do not possess any real "theory" of phylogeny. May we, at least, suppose phylogeny to be a suprapersonal evolution? We may, but only for very general and undetermined reasons; along special lines there are complications which we are not able to understand from what we know in the other fields of biology. But we are not even in possession of a warranted "system" of biological species, of a real "rational system."

With regard to history we can say a little more, because we ourselves stand in the midst of it - though even this "standing in the middle" has, on the other hand, a special and very strange disadvantage with regard to real knowledge. For we may even go as far as to say that because we are standing in the middle of history as an evolution- 
granting that it be an evolution-we cannot and shall never be able to appreciate in clearness its evolutionary character. What could an embryonic cell, say of one of the germ layers, know about the "evolutionary unity" of which it is a part, if we could endow it with the faculties of sensation and reasoning? It would at the highest "suppose" in a "hypothetical" manner that such a unity exists. And we are in the place of the reasoning embryonic cell with regard to suprapersonal unity.

And yet there are some peculiar features in " history" or, rather, in the human community, that seem to give us some signs of supra-individual totality. The first of these signs is the general biological fact of propagation. The second is what Wundt has called the "heterogeny of purposes," i.e. the fact that human action may hare quite different effects from what the agent expected-so to speak in a creative manner. The third sign of suprapersonality is morality or, rather, the fact of moral feeling in the widest sense of the word.

We say here only a few words with regard to, morality as a sign of suprapersonal unity. By this it is meant that the fact of moral feeling or, in short, conscience, is to be understood, and can only be understood, by the hypothesis that the single human person plays a particular rôle in the midst of a real evolution of mankind, and that his conscience shows him, indirectly, what rôle he plays. Thus, morality lends support to the hypothesis that mankind is a suprapersonal unity in evolution, an hypothesis which is by no means constructed ad hoc, i.e. simply 
to "explain" the existence of morality, but owes its origin to logical considerations. It is, of course, necessary to assume, in order that the hypothesis of mankind being a suprapersonal unity may really "explain" morality, that the content of the moral feeling in each person-with its two sides of pity and duty-is in fact in accordance with the general goal of human evolution, and does not mean what it does though the goal of evolution might possibly be considered as "immoral." But this additional hypothesis is by no means artificial, though, of course, it is an hypothesis.

$\checkmark$ By our conception of morality as a sign of suprapersonal evolutionary unity, "Ethics" becomes a part of "Logic," at least of the Logic of nature ; and this is very important with regard to the system of philosophy.

Returning, then, to the problem of suprapersonal unity in general, with special regard to the problem of history, it must be confessed that, apart from the "signs" of unity spoken of, we are not able to say anything more in detail about the evolutionary character of history. What in the first place seems to support the conception of history as an evolution - the fact, namely, that everything has become so complex and the so-called "progress" in art, knowledge, manufacturing and general "civilisation "-all this may also mean nothing but what we have called cumulation, and not evolution. In other words, it may be that all these complications rest only upon the faculty of the individual soul to store, so to say, all its own experiences and those of former generations. Even with respect to 
moral "progress," it may behave like this; the abandoning of slavery and torture may not rest upon a real evolutionary process, and we therefore cannot know with certainty that both these institutions will never be introduced again.

There certainly are cumulations in history, even if we grant that a main line of real evolution runs through it. And a sort of mixture of cumulation and evolution will then be discernible in any historically created system. If we call " the State" the real evolutionary suprapersonal order of mankind, we may not expect the political "states" of our times to be pure suprapersonal unities for themselves. They are each only part of the one suprapersonal unity, mixed up with cumulative contingencies-if by contingency we understand what does not belong to a special unity already recognised. The mediaeval idea of one hierarchic state came much nearer to the logical ideal of the one state as the suprapersonal order of mankind than our modern national states do.

Evolution and cumulation are certainly mixed in history, if we grant to it its hypothetic evolutionary character at all. And so it will probably be in phylogeny also; perhaps we may say here that the theories of Lamarck and Darwin account for the "cumulations" in phylogeny, whilst we are not yet -and perhaps never shall be-in possession of a theory that really tells us what sort of an "evolution" phylogeny is.

The contrast between evolution and cumulation, between contingency and unity in general now leads us to further problems. 


\section{$H$. MONISM AND DUALISM.}

In a previous paragraph of this article the concepts of logic and of nature have been defined. Logic is the theory of order in the widest sense of the word, the concept of "order" being the indefinable basis of all thinking. Nature is the totality of certain " mediate objects," meant by immediate objects or thought-contents, which behave as if they were something for themselves. If now we bring the two concepts of order and of nature together the following postulate is at once before us.

Nature is to be conceived as the one order of natural objects; only if conceived in this way, can nature be said to be "understood" ; for to understand is to conceive as an order.

This, then, is the postulate of logic, or its " ideal."

Let us first try to see what this postulate means in detail.

Strange to say, it destroys the difference between " mechanism" and "Vitalism," or between singular and unifying causality, which we have established so carefully. For it abolishes mechanism. There is no "singularity" any more in the face of the general postulate of the one natural order; the universe is an organism, or rather is the one organism. 
And the postulate of order destroys something more, something that appears to be of the greatest importance to science: it destroys the concept of the law of nature. All so-called "laws," i.e. all connexions of natural principles with regard to being or becoming which are realised in so many "cases," appear, at any rate, as nothing but features of the behaviour of that agent which orders "the nature," as features of the behaviour of the natura naturans. And these features have no guarantee in themselves of being immutable; on the contrary, they must be mutable, as certainly as nature is a something in evolution. All natural becoming is like one great embryology ; but in biological embryology we know that the "law" of mere cleavage, for instance, holds good for, say, ten cell-divisions and is then followed by the "law" of organ-formation.

Every singularity of being and becoming has its own particular place in the order of nature-so runs our postulate in another form.

We may call our postulate the postulate of monism of order. All philosophers who have tried to work a "theodicy" have seen this monism of order, Plotinus, for instance, and Leibniz; and all theologians who have written on "providence" have also seen it.

It seems at the first glance as if the abolition of the conception of "law" by means of our monistic postulate entails a great disadvantage to sciencebut only so long as we do not appreciate that something else also is to be abolished by monism, a something that may be said to be the greatest enemy of thought : chance or contingency. 
There is no contingency where there is mere order.

But now the great question arises : is the logical postulate of order or monism really to be fulfilled by what we know about nature empirically? Can we really say that we know that every singularity of nature has its single place in one great ordered totality ; that, as far as becoming is concerned, every single event is purposive or teleological with regard to a certain final state which we conceive as the ordered state? Or must we confess in spite of all logic and all logical postulates that we do not know that nature is one order, in which every singularity of being or of becoming has its one peculiar place?

This problem-the problem of monism or dualism with regard to factual natural order-is not to be solved in a final way. For, in spite of all the deficiencies of our positive knowledge with regard to order, monism may always reason in the following way :

Certainly, what we know and are even able to know about nature does not form one order if taken together; there is chance, contingency, non-teleology in what we know. But this is our fault and not the fault of nature. For we have imagined we had the whole of nature where we had only part; and only that part which is such as to be accessible to our form of apprehending reality. We can only receive the one part of reality which appears to us under the signs of spatiality. But only what we call inorganic becoming is completely accessible to us in the form of spatial signs; even individual organic becoming, as studied in biology, is marked to us only by some spatial results but not as becom- 
ing; for it is not spatial, i.e. in space, as becoming. And who can say how many kinds of being or becoming there may be in reality which are absolutely inaccessible to us, because they are not marked by spatial signs at all? And might it not be that nature would appear to us as the one order we are in search for, if only we knew all those parts of it which, by our mental organisation, we are absolutely incapable of knowing?

Such reasoning is the ultimate ratio of a monism of order. It explains our insufficiency in conceiving monism by metaphysical possibilities, i.e. by the hypothesis that there may be innumerable fields of reality not marked to us by spatial signs; it, certainly, is quite uncontrollable. But it expresses a possibility, and thus monism is not to be defeated - in an absolute manner.

'Whoever lays stress upon what is empirically known must accept the dualism of order and chance, of unity and sum-of $\epsilon \hat{i} \delta$ os and $\dot{v} \lambda \eta$ in the last resort.

In order to know where there are groups of natural facts which we are naturally unable to conceive as parts of a unity, let us first return to embryology once more. We know that embryological becoming is "vitalistic," that it is impossible to comprehend it by the laws of physics and chemistry. But does this statement apply to each singleness in the course of embryology? Certainly it does not : the position of the single cells in the different organs of the embryo or the adult is, probably in almost all cases, contingent ; and is different in each individual of the same species. Unity and unifying causality apply 
only to the arrangement of organs in general and to the general features of form-say, of the single bones of vertebrates-but not to any intimate details.

If we leave aside that large field of our ignorance, phylogeny, and turn at once to history, we meet contingency in another form. From another point of view, as we have said before, there certainly are cumulations and probably lines of evolution in history. When we said this we had not yet formulated the logical postulate of monism of order, we rather looked upon the "signs" of unity in history as something very valuable though rare. That was the method of naïve empiricism. But now we start from the postulate of monism of order and-do not find it fulfilled : and it is now not merely cumulation with regard to which we say that we are disappointed as logicians-it is chance, it is contingency in its crude and immediate reality, and, further, it is still something else. We have tried to conceive ethics as a part of the logic of reality, i.e. to conceive moral feelings as a sign of the single man's belonging to a ! suprapersonal unity in evolution. Why, then, we may now ask, are men not always "good" but very often "bad"; why is there the evil, the sin? Evil and sin seem to be non-evolutionary contingencies of the highest order. But in pure biology we have their counterpart in illness and even death.

In any case we know there are historical contingencies-at least for our human knowledge, or, better, as far as we believe that we have complete nature in spatial nature. It must be granted that, even apart from this argument our knowledge of the main points in history is very imperfect, that 
there may be "signs of unity" in it that might be accessible to us, were we but carefully to study the problem-Hegel's concept of the "List der Vernunft" is probably a suggestion that one day may lead further. But, even then, in the one case a shot reaches its mark and in another not, the marks both times being historical persons, and this appears to us to be contingent and nothing else; so long, at least, as our knowing ranks higher to us than our postulating.

This is the right place to say a few words on the methodology of history, and of all science of "culture," from the purely logical point of view. The problem has been very much discussed in recent years, particularly in Germany, but the main point, it seems to me, has generally been slurred over. On the one hand, as first in the work of Windelband, an endeavour is made to formulate what the actual method of the writers of history is at the present day; the historian too, it is said, selects and orders his material in relation to "values," i.e. centres of interest. This is certainly done, but cannot be said. to be "science" ; were it the last word of history, history would be a collection of curiosities, and would, at the best, be of moral or ethical value alone. But, on the other hand, we are told, and in particular by Buckle, Taine, Lamprecht and others, that history must try to find historical "laws." There is no doubt that this is a real theme for the historian, but, it seems to me, it is his theme more in his capacity as a sort of psychologist than as a real "historian." For these historical "laws"-quite apart from their being mere regulae, of a cumulative 
character, and not elementary laws-do not touch history as one single evolutionary process ; they also deprive history of its proper aspect of becoming. This, then, seems to me to be the real goal of the history of the future : to try to find signs of evolution in history, signs of an evolution proper to it and to nothing else; in this way history would have its place in the midst of the general theory of order and would yet be a science for itself. Herder and Hegel conceived history in this way, though not in a manner quite satisfactory, and in our days Breysig seems to follow them.

We now return to the question-monism or dualism-to attack the very centre of the problem.

Monism of order is a postulate of logic ; the whole universe should be conceived as one order. To do this is impossible on the grounds of biology proper and of history, because in both cases there is unity mixed with chance and contingency. What now is to be said about our knowledge of unity, of the one order with regard to so-called inorganic nature?

It seems at first as if the gap between ideal and reality is greater here than anywhere else; for empirical science, so far, has not even raised the question of unity, as it has done in biology and history, but has surrendered the whole material to the scheme of singular causality without hesitation. So, at least, it has been during the last decades of the history of science. Must matters remain thus? Anyone who knows a little of the scientific literature of the eighteenth century would hardly be inclined to answer this question in the affirmative. For very much was written in former days on the "general 
teleology," the "mutual harmony" of what we call to-day, rather carelessly, "inorganic" nature.

But perhaps all books about "general" and " mutual " teleology or unity have been written in a decidedly uncritical way? Granted that they are -is it not rather remarkable that a professor of biological chemistry is working in quite the same spirit at the present time?

Professor Henderson of Harvard has recently published a very remarkable book entitled The Fitness of the Environment. I do not agree with Henderson's attitude towards the problem of Vitalism; he advocates what we should call the machine-theory, i.e. a static teleological conception of life, which does not seem to meet the point. But this is quite immaterial if compared with his positive work: he has not only once more realised the problem of inorganic or, better, universal teleology, as I may also claim to have done at the end of my Gifford Lectures, but he has found the way to deal with this problem in detail, and this on the firm ground of physics, chemistry and physical chemistry. Water, carbonic acid, and "the ocean" are the chief objects of his study; and the result of his researches is that all phenomena of life are quite essentially based upon the exceptional character of all the socalled constants of $\mathrm{H}_{2} \mathrm{O}$ and $\mathrm{CO}_{2}$, if compared with the constants of all other compounds. The well-known and often discussed fact that water has its greatest density at $+4^{\circ} \mathrm{C}$. and not at freezing point is but one out of very numerous topics of his argument.

This, then, is the old problem of the harmony of nature in a modern and very exact form ; and this 
harmony is nothing but a "sign" of unity or individuality in the universe in general.

Unfortunately we must confess that it is the only "sign" of universal unity that we know exactly. But one is better than none, and, further, to have one allows us to hope thatwe may have more some day - perhaps when the distribution of land and water, of the sidereal masses, of "matter" in general has been studied with the special object of finding unity.

At present we have not more than the one sign of unity ; that consists in certain features of "fitness" for life, with regard to "inorganic" unity, i.e.- - strange to say-with regard to our conceiving the inorganic universe as an organism in the strict sense. The rest is chance or contingency. For nobody would dare to say that he understands under the point of view of unity-that " these stones here in this forest are lying just in the way they are." But for monism of order as a matter of knowledge-and not as a mere postulate of logic as the theory of order-this would be necessary.

This, then, is the general result of our inquiry : Monism of order as a postulate, Dualism of order and chance as the fact. And the only possibility of saving the postulate of monism in spite of our knowing about dualism, is to have recourse to metaphysical possibilities, unknowable in principle, i.e. to the hypothesis that there may " be " certain areas of reality which have no spatial signs, human experience being bound to spatiality and therefore not able to solve even the biological problem quite satisfactorily. ${ }^{1}$

1 See above, page 225. 


\section{METAPHYSICAL CONCLUSIONS.}

All our discussions on Vitalism, suprapersonal unity, monism of order and dualism, and so on, with one single exception, ${ }^{1}$ have, so far, been absolutely independent of any kind of metaphysics, hare been throughout non-metaphrsical. This assumes that the word "metaphysics" is to signify a doctrine that tries to deal with " being " without reference to whether this being is consciously had by myself, i.e. with being in itself. It appears to me that this statement must be explained in some detail.

Logic as the theory of order deals with everything that is object to myself, that is consciously had by myself. The totality of immediate objects, then, are my objects, and their order is my order ; the signs of order, i.e. the irreducible fundamentals of logic as "this," "such," "relation," etc., being found by my introspection. And all postulates of the theory of order, as regards geometry or the theory of becoming or whaterer else, are my postulates. And if, further on, nature is regarded as a totality of mediate objects, only "meant" or "signified "by immediate objects or thought-contents, as a totality

${ }^{1}$ See page 226, where we tried to "save" the monism of order on the basis of certain metaphysical assumptions. 
that behaves as if it were something independent in itself, in particular with respect to becoming - this concept of nature is also $m y$ concept, is created by myself in the service of the theory of order which is mine.

But this solipsistic conception of logic and of logic of nature is by no means dogmatic. For I have not said : " the world of my objects, both immediate and mediate or natural, is only my world." But I have said: "it is my world in any case," or, in other words : " this it is that I know : it is my world." We may speak here of solipsism as a critical method or of methodological solipsism; and this methodological solipsism is the true critical philosophy, i.e. the one philosophy that tries to stand on firm ground and not to say anything from a dogmatic point of view that can be said non-dogmatically.

Thus, then, all our theory of nature, as a part of the theory of order, has been non-dogmatic, and, in particular, non-metaphysical. And this theory of nature includes the theory of Vitalism proper, of suprapersonal unity in its different possible forms, of monism and dualism. All these theoretical formulations are purely analytical and independent of any metaphysical conception whatsoever. Those who prefer it may regard these purely analytical formulations as the last possible word with regard to nature ; for them our work finishes here.

But, in my opinion, though overstepping the boundaries of solipsism certainly means giving up the firm ground of reasoning, solipsism is by no means satisfactory. There is something in it that appears as a gap. Or, in other words : for mere 
reasons of order the solipsistic theory of order must try to come out of itself, to become something other than it was, namely, metaphysics, or a system of hypothetical statements about something that is not merely mine; though, of course, it must have the faculty to become also mine, otherwise I should not be able to deal with it at all.

If we here neglect the problems of psychology and of ethics, it is clear that it is the mere logical concept of nature that forces us to go beyond mere solipsism. Nature "as if" it were an independent community of (mediate) objects-this is not a solution, but only the way to one. Why not say: Nature the sign of "real" or "absolute" independence? At least we may do our best, i.e. try to formulate a system of statements about "reality" in a hypothetical form. This system of metaphysical statements, of course, must be such as to explain not only nature as an object but also my consciously having nature; in other words, the purely solipsistic analytical theory of nature and of my "having" nature must be a consequence of the metaphysical theory-were it not, metaphysics would be valueless.

Metaphysics, then, must start from my knowledge of nature (and psychology); its method can be nothing but "induction," i.e. the endeavour to formulate statements from which known statements follow; for this is the deeper meaning of the term "induction." Never, of course, can metaphysics become a system of statements that possess absolute certainty: metaphysics always must be hypothetical in the strict sense of the word. For, 
as was said, it goes from the consequences to the reasons, and it is a well-known logical truth, that " affirmation of a consequence does not mean affirmation of the reason," or, in other words : a consequence may have had various reasons.

It cannot be our aim here, of course, to develop a system of metaphysics; not even a sketch of a metaphysical system can be given. We shall only say a few words about those metaphysical questions which are intimately connected with the problem of Vitalism in the widest sense.

It is meaningless to raise the question, whether any feature of natural reality in its empirical suchness or quality be "the same" as the suchness of a. feature of absolute reality taken "in itself," or whether it be only an "image" of the absolute suchness. For in order to decide this question we should have to compare a something "for myself" with a something only in so far as it is " in itself "; and this is impossible, because the "in itself" must become "for myself" in order to be known at all.

The question, then, is meaningless whether to spatiality as experienced in nature corresponds a something in the absolute sphere that is also "spatial." But we may safely say that, just as all experienced spatiality implies belonging to one and the same special system of relations, so also everything that corresponds to the quality of spatiality in the Absolute belongs to one and the same kind of system of relations, and not to different systems. Space then-and the same holds for time, though in a somewhat different way-is to us a sign of one special system of relations in the Absolute. 
Now we have seen that what we have called singular causality fully appears to us in space, but that unifying or individualising causality, as one of the three other forms of possible becoming in nature, has only, so to say, points of effect in space, but is not in space as becoming. Quite apart from time, then, there is certainly one special system of relations in the absolute, besides the one that corresponds to experienced spatiality ; and we only know about this system in so far as it cuts, so to speak, across the system which we know under the sign of spatiality. It is for this reason that, even in the realm of the mere theory of order, we only know about the existence, but not about the suchness of entelechy taken for itself.

Our knowledge of the absolute existence of more than one special system of relations-apart from time-only one of which, under the form of spatiality, is signified to our experience in completeness, is of fundamental importance for our comprehension of Absoluteness in general; it shows us at once that there are features of the Absolute about which we have no signified knowledge. Of what we may call the "vital system" of relations we have at least some incomplete signs-in our knowledge of the points of intersection of this system with the system signified by space. But how many systems of relations may there be, of which we are absolutely unable to know anything at all ? Let us recall how by admitting the possibility of unknowable systems of relations in the Absolute, we were able to save monism of order in principle. ${ }^{1}$

$$
{ }^{1} \text { Cf. p. } 226 .
$$


The concept of universal determination governs the whole of the theory of order, and the theory of natural becoming in particular-in the form of a connexion of becoming in itself, as if there were reasons and consequences in it: and the greatest difficulty of metaphysics is the problem whether this concept of determination, with special regard to becoming, holds good, i.e. means something in the metaphysical sphere, or not. If not, the theory of order would have to lose one of its most important concepts in favour of metaphysics. We, indeed, have pressed the concept of determination as far as we could, and have even regarded history as a suprapersonal evolution determined in its becoming by a suprapersonal entelechy. This predetermination of historical becoming, it is true, was of no practical use to us, for we do not know entelechies apart from their manifestations; but it was there in principle, and this the theory of order had to state; and, according to this theory, it would be possible to imagine a supra-Laplacian mind which, in possession of a knowledge of all pure entelechies, might predict historical evolutionary becoming.

We therefore raise the question whether the theory of the predetermination and univocality of all becoming is more than an outgrowth of the limited character of the human mind; whether at least suprapersonal evolutionary becoming, as shown to us in phylogeny and history, may not be undetermined or, to use a common word in its strict meaning, may be free. Freedom is not to mean here that the single individuals in a suprapersonal unity are free from, i.e. completely independent of, one another ; 
this possibility, or, in other words, a true monadistic theory, is excluded by our concept of suprapersonal unity from the beginning. But freedom means that a stream, as it were, of undetermined becoming of a really creative character runs through the totality of individuals; whereas, if metaphysics decide not to admit freedom, an immaterial suprapersonal agent would reveal itself in its own suchness in the course of phylogeny and history. With the first alternative there arises something that is really new in the course of becoming; with the second there is nothing "new" as regards the principal features of the manifoldness of what becomes, and only its materialisation is something " new." Our problem is the problem of pantheism or theism in a special form: at least, if we call pantheism the one doctrine that reality is a something which is making itself (" dieu se fait," in the words of Bergson), whilst theism would be any theory according to which the manifoldness of material reality is predetermined in an immaterial way. There is no doubt that in this sense many of the emanationsystems would be theistic ststems also, and not only those systems that accept the concept of creation proper. In any case there seems to me to be a greater difference between what we have called pantheism and the systems of emanation, than between emanation and creation-if emanation means that all suchness and manifoldness of knowable reality is predetermined in the Absolute in any way.

The problem is, then, accurately formulated; but now we see at once that ve cannot solve it; and this 
for the very reason which prevents all metaphysics from going beyond probabilities or even mere possibilities.

What we know is the impossibility of a prediction of further states of suprapersonal evolution from the states already reached and known; what we postulate in the field of the theory of order is that impossibility of prediction does not mean indetermination. The following metaphysical question arises: does the Absolute agree with our postulate or not? But we only know about metaphysics that its statement must be such as to render possible "experience" in the widest sense. Now it is clear that " experience," i.e. our knowledge of the impossibility of making predictions about future states of evolution, would be equally what it is, whether there be indetermination in the Absolute or a sort of determination unknowable to us.

The problem of theism or pantheism, then, must remain unsolved and surrendered to belief; and we may only say that those who regard the thesis of the theory of order as necessary for everything that is or can be, must accept theism and are not allowed to speak of "dieu qui se fait." But to accept theism would again mean to accept a number of alternatives among which it is impossible to decide. 




\section{Date Due}

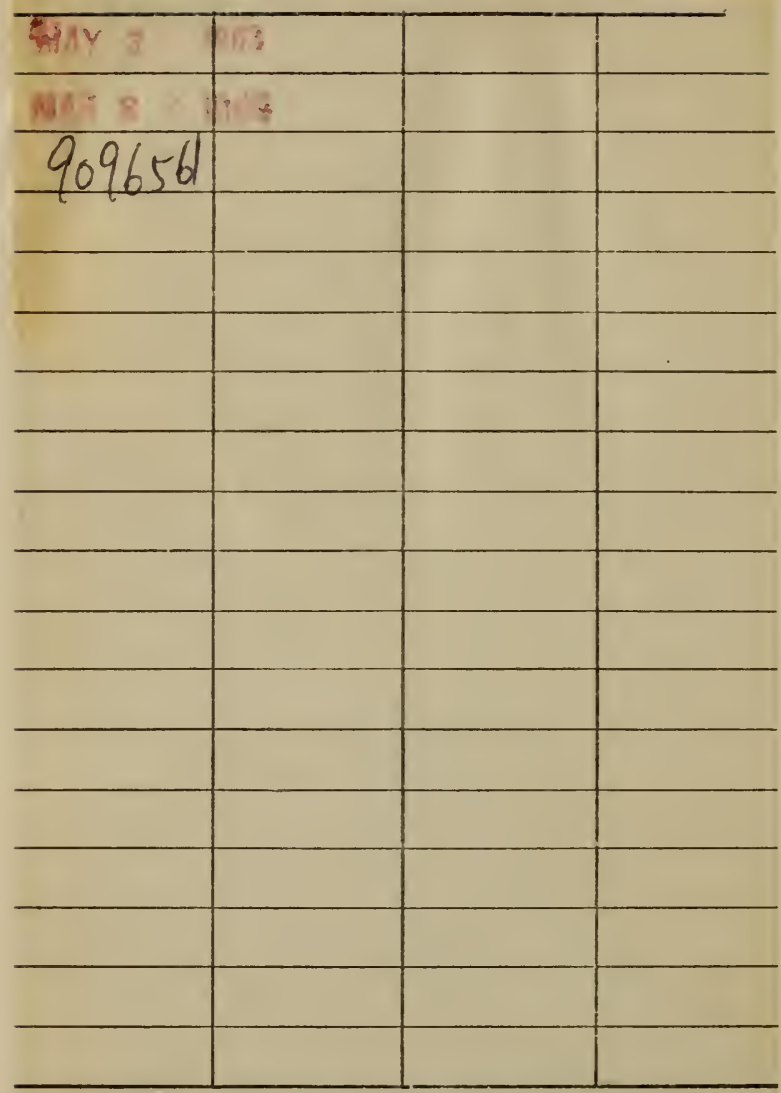

L. B. Cat. No. II 37 


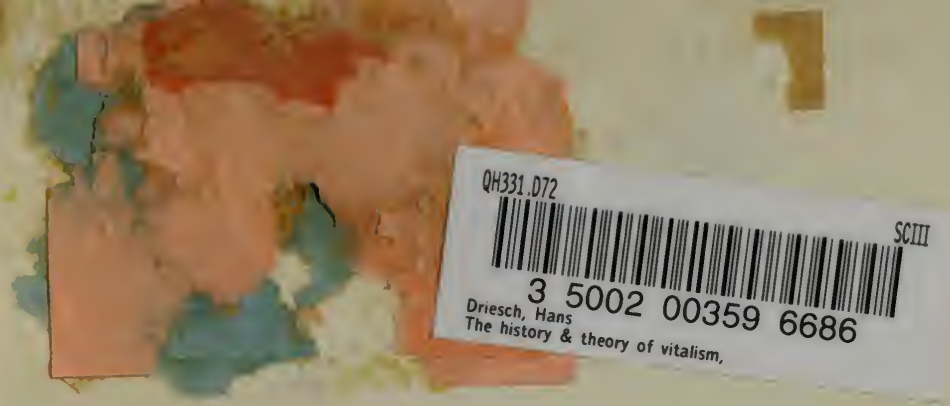

Sclence QH 331 . D72

Driesch, Hans, 1867-1941.

The history \& theory of vitalism 


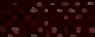

$\therefore \therefore 8 \% 8 \% \therefore 8$

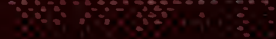
$\therefore \quad \therefore$

$\therefore$

$\because \cdots$ 